INSTITUTO SUPERIOR ANÍSIO TEIXEIRA

\author{
Luana Cunha Figueiredo
}

UM ESTUDO DE CASO SOBRE A ANSIEDADE NA APRENDIZAGEM DE LÍNGUA ESTRANGEIRA

São Gonçalo - RJ

2020 
Luana Cunha Figueiredo

\title{
UM ESTUDO DE CASO SOBRE A ANSIEDADE NA APRENDIZAGEM DE LIINGUA ESTRANGEIRA
}

\begin{abstract}
Monografia apresentada ao curso de Bacharelado em Letras Tradução PortuguêsInglês do Instituto Superior Anísio Teixeira ISAT como requisito parcial à obtenção do título de Bacharel em Letras Português-Inglês.
\end{abstract}

Orientador: Prof. M. ${ }^{\mathrm{e}}$ José Manuel da Silva

São Gonçalo - RJ

2020 


\section{UM ESTUDO DE CASO SOBRE A ANSIEDADE NA APRENDIZAGEM DE LÍNGUA ESTRANGEIRA}

Monografia apresentada ao curso de Bacharelado em Letras Tradução PortuguêsInglês do Instituto Superior Anísio Teixeira ISAT como requisito parcial à obtenção do título de Bacharel em Letras Português-Inglês.

Orientador: Prof. M. ${ }^{\mathrm{e}}$ José Manuel da Silva

Prof. M. ${ }^{e}$ José Manuel da Silva - ISAT

São Gonçalo, RJ, 20 de julho de 2020. 


\section{DEDICATÓRIA}

Aos meus pais, Monica e Marcos. 


\section{AGRADECIMENTOS}

Agradeço a Deus pelos ensinamentos e por ter permitido que eu realizasse os meus sonhos com saúde.

Aos meus pais por todo amor incondicional, cuidado, carinho, pela atenção e pelo apoio emocional e financeiro, não só ao longo desses quatro anos, mas também ao longo de toda minha vida.

Ao meu melhor amigo, Anderson Junior, por todo incentivo, suporte, pelo tempo que passamos estudando e planejando nosso futuro juntos e pelo amor fraternal que temos um pelo outro.

À minha melhor amiga, Marcella Albernaz, que esteve comigo desde o início, me encorajando e me incentivando a seguir em frente e, é claro, sonhando esse sonho comigo.

Às minhas colegas de classe, Lorena Vidal e Thamires Passos, por todo companheirismo e pela amizade ao longo da faculdade, fazendo com que os dias fossem mais leves e divertidos.

À minha psicóloga, Camilla Freitas, por todo apoio emocional e carinho para que eu pudesse vencer cada barreira encontrada.

A todos os professores do ISAT que contribuíram para o meu crescimento acadêmico e profissional.

Agradeço, em especial, ao Professor Mestre José Manuel pela orientação, compreensão, e por ter acreditado em meu potencial. 
Tu me ensinas, eu lembro.

Tu me dizes, eu esqueço.

Tu me envolves, eu aprendo.

Benjamin Franklin 


\section{RESUMO}

A ansiedade na aprendizagem de língua estrangeira tem sido objeto de diversos estudos tanto na área da psicologia quanto na área da educação, visto que pode ser um fator que contribui para o insucesso no processo de ensino-aprendizagem. Em se tratando dos bloqueios emocionais vividos pelos alunos de língua estrangeira, a afetividade tem sido tratada como um dos pilares para a melhora da qualidade de vida em sala de aula. Neste trabalho, o intuito é apresentar os indícios da ansiedade nas aulas de língua inglesa e francesa como língua estrangeira, conhecer as crenças e os bloqueios dos alunos e buscar entender como a afetividade entre professor e aluno pode representar um importante papel no processo de ensinoaprendizagem de língua estrangeira.

Palavras-chave: ansiedade. aprendizagem de língua estrangeira. ensinoaprendizagem. bloqueios emocionais. crenças. afetividade. 


\begin{abstract}
Anxiety in foreign language learning has been the focus of several studies both in the area of psychology and in the area of education, given the fact that it can be a factor that contributes to the failure in the teaching-learning process. In the case of emotional blockages experienced by foreign language students, affectivity has been treated as one of the pillars for improving the quality of life in the classroom. This work aims to present the signs of anxiety in classes of English and French as a foreign language, to know students' beliefs and blockages, and to try to understand how the affectivity among teachers and students can play an important role in the teaching-learning process of foreign languages.
\end{abstract}

Key words: anxiety. foreign language learning. teaching and learning. emotional blockages. beliefs. affectivity. 


\section{LISTA DE GRÁFICOS}

Gráfico 1 - Desconforto com as habilidades segundo os professores de francês e

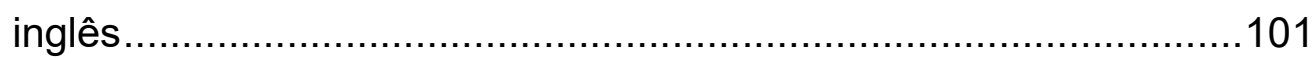

Gráfico 2 - Desconforto com a fala segundo os alunos de francês e inglês .............101

Gráfico 3 - Desconforto com a escrita segundo os alunos de francês e inglês ........102 Gráfico 4 - Desconforto em responder perguntas segundo os alunos de francês e

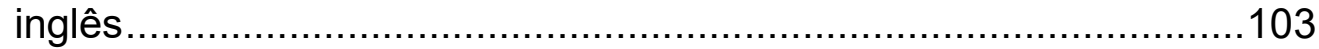

Gráfico 5 - Sentimento de motivação segundo os alunos de francês e inglês..........103

Gráfico 6 - Sentimento de ansiedade segundo os alunos de francês e inglês .........104 Gráfico 7 - Identificação de alunos ansiosos segundo os professores de francês e inglês. 105 


\section{LISTA DE QUADROS}

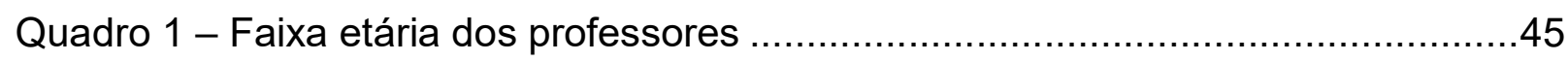

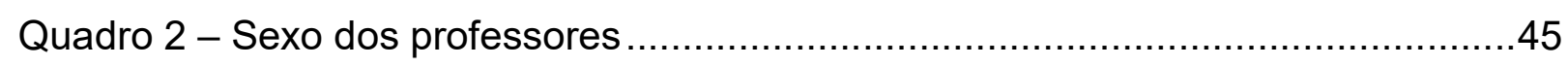

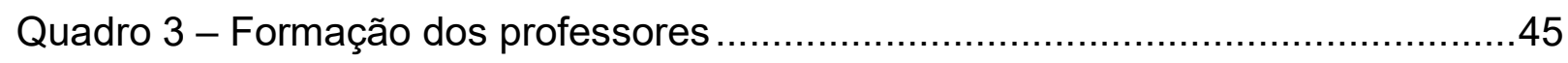

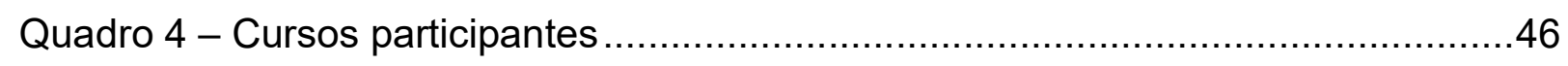

Quadro 5 - Faixa etária dos alunos cursando francês ...........................................47

Quadro 6 - Sexo dos alunos cursando francês ....................................................4

Quadro 7 - Nível dos alunos cursando francês..................................................48

Quadro 8 - Formação dos alunos cursando francês...............................................48

Quadro 9 - Faixa etária dos alunos cursando inglês.................................................48

Quadro 10 - Sexo dos alunos cursando inglês .....................................................49

Quadro 11 - Nível dos alunos cursando inglês .....................................................49

Quadro 12 - Formação dos alunos cursando inglês ...............................................49

Quadro 13 - Faixa etária dos alunos formados em francês ......................................49

Quadro 14 - Sexo dos alunos formados em francês ............................................50

Quadro 15 - Nível dos alunos formados em francês ...........................................50

Quadro 16 - Formação dos alunos formados em francês.........................................50

Quadro 17 - Faixa etária dos alunos formados em inglês .......................................51

Quadro 18 - Sexo dos alunos formados em inglês ................................................51

Quadro 19 - Nível dos alunos formados em inglês ..............................................51

Quadro 20 - Formação dos alunos formados em inglês .........................................52

Quadro 21 - Formação dos alunos participantes.................................................52

Quadro 22 - Siglas de identificação dos participantes ............................................53

Quadro 23 - Respostas dos professores - habilidades - Pergunta 1 .......................59

Quadro 24 - Respostas dos professores - Pergunta 1 ..........................................59

Quadro 25 - Respostas dos professores - Pergunta 2..........................................60

Quadro 26 - Respostas dos professores - afetividade - Pergunta 3 .......................61

Quadro 27 - Respostas dos professores - Pergunta 3..........................................61

Quadro 28 - Respostas dos professores - alunos que falam outros idiomas -

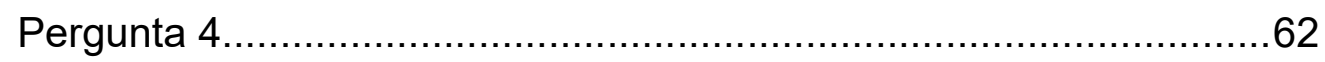

Quadro 29 - Respostas dos professores - Pergunta 4 .........................................62

Quadro 30 - Respostas dos professores - alunos ansiosos - Pergunta 5 .................63

Quadro 31 - Respostas dos professores - Pergunta 5.......................................63 
Quadro 32 - Respostas dos professores - idiomas - Pergunta 6 .64

Quadro 33 - Respostas dos professores - Pergunta 6. .64

Quadro 34 - Respostas dos alunos cursando francês - Pergunta 1 .66

Quadro 35 - Respostas dos alunos formados em francês - Pergunta 1 .66

Quadro 36 - Respostas dos alunos cursando francês - motivação - Pergunta 2

Quadro 37 - Respostas dos alunos formados em francês - motivação -

Pergunta 2 . .67

Quadro 38 - Respostas dos alunos cursando francês - Pergunta 2 ... .67

Quadro 39 - Respostas dos alunos formados em francês - Pergunta 2 .68

Quadro 40 - Respostas dos alunos cursando francês - Pergunta 3 .68

Quadro 41 - Respostas dos alunos formados em francês - Pergunta 3 69

Quadro 42 - Respostas dos alunos cursando francês - afetividade - Pergunta 4 .....69

Quadro 43 - Respostas dos alunos formados em francês - afetividade -

Pergunta 4. .70

Quadro 44 - Respostas dos alunos cursando francês - Pergunta 4 .70

Quadro 45 - Respostas dos alunos formados em francês - Pergunta 4 .70

Quadro 46 - Respostas dos alunos cursando francês - conforto com as habilidades - Pergunta 5

Quadro 47 - Respostas dos alunos formados em francês - conforto com as habilidades - Pergunta 5 . .72

Quadro 48 - Respostas dos alunos cursando francês - Pergunta 5 .72

Quadro 49 - Respostas dos alunos formados em francês - Pergunta 5 .73

Quadro 50 - Respostas dos alunos cursando francês - desconforto com as habilidades - Pergunta 6

Quadro 51 - Respostas dos alunos formados em francês - desconforto com as habilidades - Pergunta 6 . .74

Quadro 52 - Respostas dos alunos cursando francês - Pergunta 6 .74

Quadro 53 - Respostas dos alunos formados em francês - Pergunta 6 .75

Quadro 54 - Respostas dos alunos cursando francês - Pergunta 7 .76

Quadro 55 - Respostas dos alunos formados em francês - Pergunta 7 . .76

Quadro 56 - Respostas dos alunos cursando francês - sentimentos - Pergunta 8 ...77 Quadro 57 - Respostas dos alunos formados em francês - sentimentos -

Pergunta 8. .78

Quadro 58 - Respostas dos alunos cursando francês - Pergunta 9 .79 
Quadro 59 - Respostas dos alunos formados em francês - Pergunta 9 .79

Quadro 60 - Respostas dos alunos cursando francês - Pergunta 10 .80

Quadro 61 - Respostas dos alunos formados em francês - Pergunta 10 .80

Quadro 62 - Respostas dos alunos cursando francês - Pergunta 11

Quadro 63 - Respostas dos alunos formados em francês - Pergunta 11

Quadro 64 - Respostas dos alunos cursando inglês - Pergunta 1

Quadro 65 - Respostas dos alunos formados em inglês - Pergunta 1

Quadro 66 - Respostas dos alunos cursando inglês - motivação - Pergunta 2.

Quadro 67 - Respostas dos alunos formados em inglês - motivação - Pergunta 2 ..84

Quadro 68 - Respostas dos alunos cursando inglês - Pergunta 2 .85

Quadro 69 - Respostas dos alunos cursando inglês - Pergunta 2

Quadro 70 - Respostas dos alunos cursando inglês - Pergunta 3 .86

Quadro 71 - Respostas dos alunos formados em inglês - Pergunta 3. .86

Quadro 72 - Respostas dos alunos cursando inglês - afetividade - Pergunta 4

Quadro 73 - Respostas dos alunos formados em inglês - afetividade - Pergunta 4 .87

Quadro 74 - Respostas dos alunos cursando inglês - Pergunta 4

Quadro 75 - Respostas dos alunos formados em inglês - Pergunta 4

Quadro 76 - Respostas dos alunos cursando inglês - conforto com as habilidades - Pergunta 5

Quadro 77 - Respostas dos alunos formados em inglês - conforto com as habilidades - Pergunta 5 .89

Quadro 78 - Respostas dos alunos cursando inglês - Pergunta 5 .89

Quadro 79 - Respostas dos alunos formados em francês - Pergunta 5

Quadro 80 - Respostas dos alunos cursando inglês - desconforto com as habilidades - Pergunta 6

Quadro 81 - Respostas dos alunos formados em inglês - desconforto com as habilidades - Pergunta 6

Quadro 82 - Respostas dos alunos cursando inglês - Pergunta 6

Quadro 83 - Respostas dos alunos formados em inglês - Pergunta 6 .92

Quadro 84 - Respostas dos alunos cursando inglês - Pergunta 7 .93

Quadro 85 - Respostas dos alunos formados em inglês - Pergunta 7 .93

Quadro 86 - Respostas dos alunos cursando inglês - sentimentos - Pergunta 8.....94 Quadro 87 - Respostas dos alunos formados em inglês - sentimentos - 
Quadro 88 - Respostas dos alunos cursando inglês - Pergunta 9 .......................96

Quadro 89 - Respostas dos alunos formados em inglês - Pergunta 9..................96

Quadro 90 - Respostas dos alunos cursando inglês - Pergunta 10 ......................97

Quadro 91 - Respostas dos alunos formados em inglês - Pergunta 10.................97

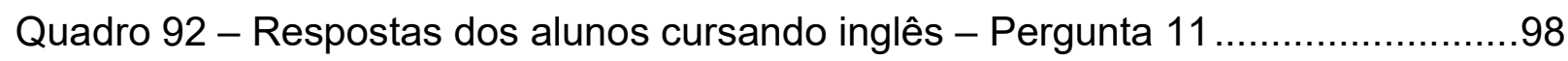

Quadro 93 - Respostas dos alunos formados em inglês - Pergunta 11 .................98 


\section{LISTA DE SIGLAS}

BALLI - Beliefs About Language Learning Inventory

CO - Compreensão Oral

CF1 - Cursando Francês 1

CF2 - Cursando Francês 2

CF3 - Cursando Francês 3

CF4 - Cursando Francês 4

Cl1 - Cursando Inglês 1

$\mathrm{Cl} 2$ - Cursando Inglês 2

$\mathrm{Cl} 3$ - Cursando Inglês 3

$\mathrm{Cl} 4$ - Cursando Inglês 4

CFPR - Curso de Francês Privado

CIPR1 - Curso de Inglês Privado 1

CIPR2 - Curso de Inglês Privado 2

CLEGOV 1 - Curso de Línguas Estrangeiras do Governo 1

CLEGOV 2 - Curso de Línguas Estrangeiras do Governo 2

CLEGOV 3 - Curso de Línguas Estrangeiras do Governo 3

EMC - Ensino Médio Completo

EMI - Ensino Médio Incompleto

E - Escrita

$\mathrm{F}$ - Fala

FF1 - Formado em Francês 1

FF2 - Formado em Francês 2

FF3 - Formado em Francês 3

FF4 - Formado em Francês 4

Fl1 - Formado em Inglês 1

FI2 - Formado em Inglês 2

FI3 - Formado em Inglês 3

FI4 - Formado em Inglês 4

GU - Gramática Universal

IDATE - Inventário de Ansiedade Traço-Estado

LDB - Lei de Diretrizes e Bases da Educação Nacional

$\mathrm{L}$ - Leitura 
LE - Língua Estrangeira

PCN - Parâmetros Curriculares Nacionais

PÓS - Pós-Graduação

PF1 - Professor de Francês 1

PF2 - Professor de Francês 2

PI1 - Professor de Inglês 1

PI2 - Professor de Inglês 2

QCER - Quadro Comum Europeu de Referência para Línguas

$\mathrm{SL}$ - Segunda Língua

SEM - Sem Ensino Médio

SC - Superior Completo

SI - Superior Incompleto 


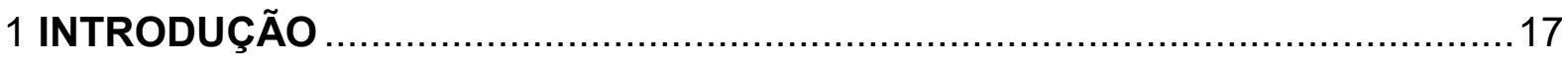

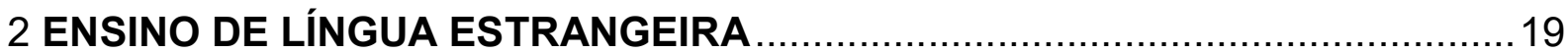

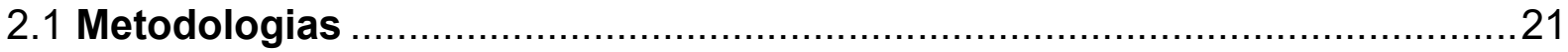

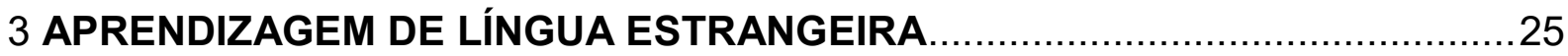

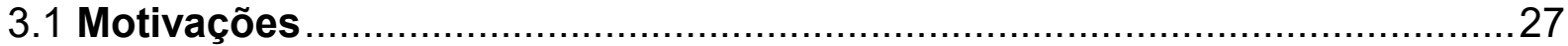

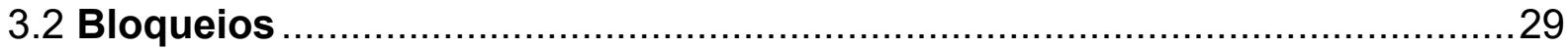

4 ANSIEDADE

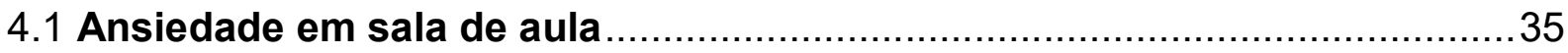

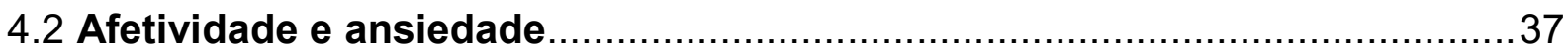

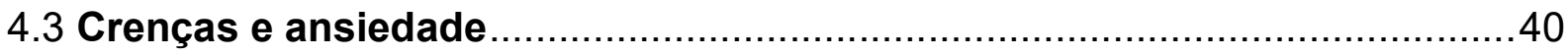

5 ANSIEDADE LINGUÍSTICA EM AULAS DE INGLÊS E FRANCÊS

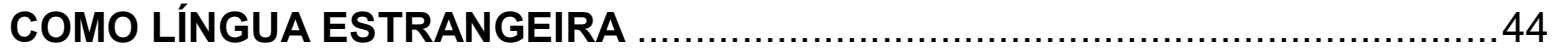

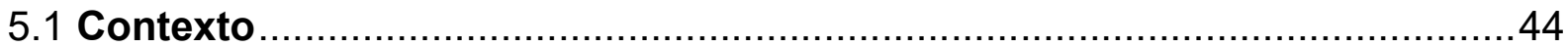

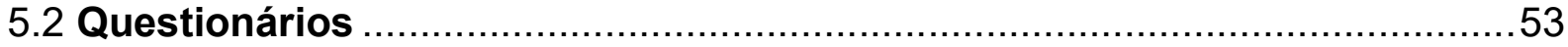

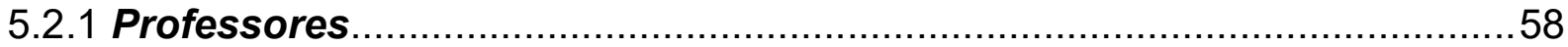

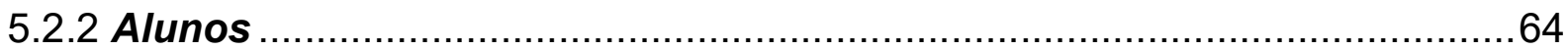

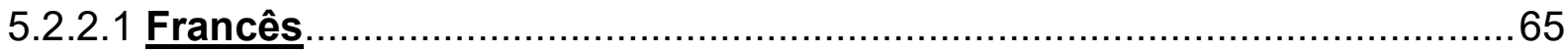

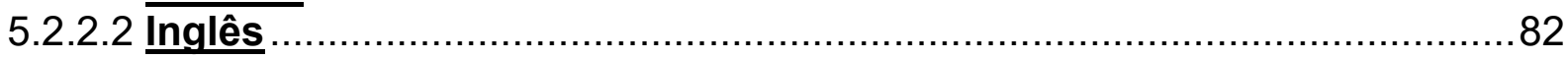

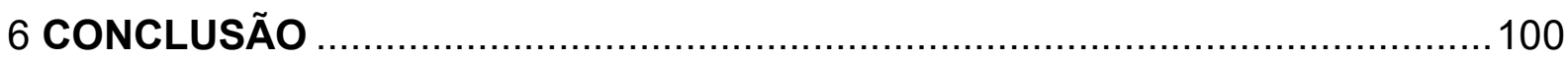

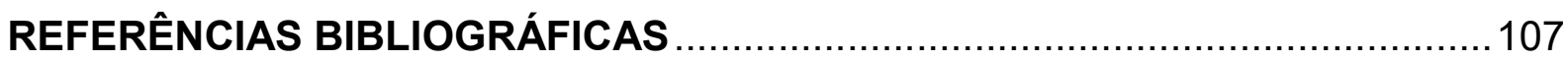

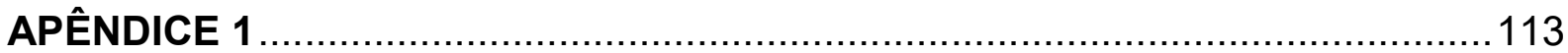

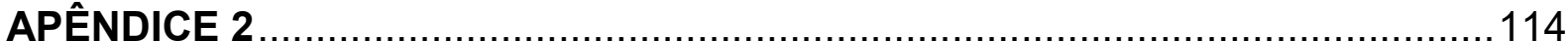

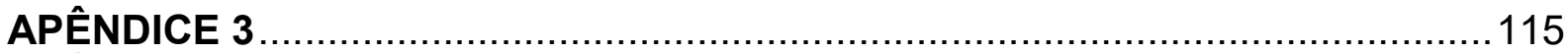

APÊNDICE 4

APÊNDICE 5 


\section{INTRODUÇÃO}

O mundo globalizado e a sociedade moderna fazem com que a procura pela aprendizagem de uma língua estrangeira aumente cada vez mais. Muitas pessoas acabam encontrando motivação para aprender um novo idioma para obterem uma boa proposta de emprego, por interesse na cultura de forma geral e/ou devido ao desejo natural do ser humano de aprender.

Contudo, como aponta Brun (2003), aprender um novo idioma vai muito além da capacidade cognitiva e da motivação dos alunos que decidem encarar essa jornada. Segundo o autor, fatores extralinguísticos, ou seja, fatores que não dependem da gramática, sintaxe e morfologia de uma língua, podem fazer com que os alunos enfrentem obstáculos na aprendizagem.

O ser humano é um ser subjetivo, dotado de emoções, que envolvem atitudes, comportamentos, crenças, sentimentos e valores. O modo como os alunos se relacionam com suas próprias emoções e com o meio sociocultural em que vivem pode influenciar diretamente sua aprendizagem.

O meio sociocultural e o sentimento tomados como objeto para este trabalho foram, respectivamente, a sala de aula e a ansiedade que pode ser despertada nos alunos de língua estrangeira. Portanto, o problema abordado nesta pesquisa é o entendimento da ansiedade como um possível bloqueio na aprendizagem de língua estrangeira e, com isso, a importância do reconhecimento da ansiedade e a busca por estratégias que auxiliem na diminuição e/ou eliminação deste transtorno em sala de aula.

Como apontam Horwitz, Horwitz e Cope (1986), a ansiedade dentro do contexto de sala de aula de língua estrangeira é definida como ansiedade linguística, visto que a língua é a responsável por despertar o sentimento de ameaça nos alunos.

Para este trabalho, além da pesquisa bibliográfica, a fim de investigar a ansiedade linguística vivenciada por alunos adultos, foi feita uma pesquisa de campo em diferentes escolas de idiomas de línguas inglesa e francesa, particulares e públicas.

Desta forma, a metodologia de pesquisa deste trabalho consistiu em aplicar questionários para alunos e professores das diferentes escolas de idiomas 
escolhidas pela autora com o intuito de analisar como a ansiedade se desenvolve dentro do contexto educacional.

Em seguida, foi feita a análise qualiquantitativa dos dados obtidos com os questionários, considerando as questões relevantes acerca do problema levantado nesta pesquisa.

O Capítulo 2 apresenta o histórico do ensino de língua estrangeira no Brasil, de forma diacrônica. Além disso, mostra as diferentes metodologias utilizadas ao longo dos anos e quais obtêm resultados positivos até os dias atuais.

O Capítulo 3 apresenta o conceito de aprendizagem de língua estrangeira e como esse processo se desenvolve. Ademais, o capítulo aponta quais são os fatores que podem contribuir para o sucesso e o insucesso da aprendizagem de língua estrangeira.

O Capítulo 4 define o conceito de ansiedade, tanto no aspecto psicológico quanto no aspecto linguístico, buscando entender como esse sentimento é despertado no ser humano. O capítulo ainda busca entender como dois outros fatores, sendo eles a afetividade e as crenças, podem contribuir de maneira positiva ou negativa para o processo de ensino-aprendizagem.

O Capítulo 5 apresenta o estudo de caso da ansiedade na aprendizagem de língua estrangeira (inglês e francês) e a análise dos dados obtidos a partir dos questionários feitos com alunos adultos e professores de diferentes escolas de idiomas, públicas e privadas.

Finalmente, o Capítulo 6 apresenta as conclusões deste trabalho. 


\title{
2 ENSINO DE LÍNGUA ESTRANGEIRA
}

O ensino de línguas estrangeiras no Brasil iniciou-se muito antes do que se imagina. Até então desconhecida pelos nativos, a língua portuguesa começou a ser ensinada aos indígenas quando os portugueses chegaram em terras brasileiras, em 1500.

Os jesuítas ensinavam a língua portuguesa e também as línguas clássicas, como o latim e o grego, com a finalidade de catequizar e impor sua cultura aos povos locais. Conforme Piletti (1991, p. 31 apud SILVA; SOARES, 2012, p. 82):

\begin{abstract}
Nas aldeias, ou em escolas ambulantes improvisadas, os índios recebiam dos europeus conhecimentos enriquecedores e novos que vinham sempre, da parte do colonizador, acompanhados da intenção de aprisioná-los ao mundo e à cultura do homem branco, retirando-Ihes a autonomia.
\end{abstract}

Portanto, o ensino de línguas estrangeiras faz parte da tradição e cultura do Brasil, primeiramente com as línguas clássicas (grego e latim) e, posteriormente, com as línguas modernas.

Durante o período colonial, as línguas clássicas eram as línguas predominantes. Contudo, somente com a chegada da Família Real, em 1808, é que as línguas modernas começaram a ganhar um destaque.

Segundo Leffa (2016), o ensino das línguas modernas no império sofria com dois grandes problemas. O primeiro era a metodologia utilizada na época, que se baseava em ensinar as línguas vivas da mesma maneira que se ensinava as línguas mortas, ou seja, fazendo traduções de textos e análises da gramática. O outro problema consistia na má administração dos currículos escolares. Para Chagas (1957, p. 88 apud LEFFA, 2016, p. 51), "subtraiu-se à escola a sua função primordial de ensinar, e educar, e formar, para relegá-la à burocrática rotina de aprovar e fornecer diplomas".

A partir de então, o ensino de línguas estrangeiras durante o império começou a entrar em decadência e a ser desprestigiado nas escolas. Os alunos estudavam de quatro a seis línguas, mas a carga horária delas passou a ser reduzida expressivamente com o passar dos anos.

Durante a República, a carga horária do ensino de línguas estrangeiras sofreu uma redução ainda maior. $O$ inglês e o alemão eram as únicas línguas oferecidas, porém 0 aluno deveria optar por uma delas, não podendo cursá-las simultaneamente. Nessa época, o ensino de grego sumiu. 
A frequência livre nas disciplinas contribuiu ainda mais para o desprestígio das línguas estrangeiras. Chagas (1957, p. 89 apud LEFFA, 2016, p. 53) afirma:

\begin{abstract}
Se antes não se estudavam os idiomas considerados facultativos, a esta altura já não se aprendiam nem mesmo os obrigatórios, simplesmente porque ao anacronismo dos métodos se aliava a quase-certeza das aprovações gratuitas.
\end{abstract}

Contudo, em 1931, com a criação do Ministério de Educação e Saúde Pública e da Reforma de Francisco de Campos, o ensino de línguas estrangeiras no Brasil começou a ser visto com um olhar diferente. A frequência livre nas disciplinas desapareceu, dando lugar ao regime obrigatório. Com a diminuição da carga horária do latim, as línguas modernas passaram a ter uma carga maior no currículo, visando a preparação dos alunos para a universidade e a formação dos adolescentes.

No entanto, a mudança mais significativa foi na metodologia utilizada no ensino de línguas. A tradução de textos e as análises gramaticais com base nas línguas clássicas foram deixadas de lado e o método direto, isto é, o ensino da língua através da própria língua, passou a ser utilizado.

Segundo Leffa (2016), os "anos dourados" do ensino de língua estrangeira no Brasil foram nas décadas de 1940 e 1950, com a implementação da Reforma de Capanema. A Reforma deu grande importância ao ensino de línguas, mantendo o método direto, porém enfatizando que o ensino de LE deveria ir além das quatro habilidades (leitura, escrita, fala e compreensão oral). $O$ ensino de línguas deveria contribuir para a formação e o desenvolvimento mental e cultural dos alunos.

Em 1996, uma nova LDB (Lei de Diretrizes e Bases da Educação Nacional) foi implementada, obrigando o ensino de uma língua estrangeira - sua escolha ficava a critério da instituição - a partir da quinta série do ensino fundamental. Por outro lado, em relação ao ensino médio, duas línguas estrangeiras eram oferecidas, uma obrigatória e outra optativa - as escolhas de oferta também ficavam a critério da unidade escolar.

Tendo em vista o pluralismo de ideias, a utilização de uma única metodologia correta para o ensino de LE foi rejeitada, porém a mais comum era a sociointeracionista, com maior foco na leitura. Contudo, Leffa $(2016$, p. 61) afirma que: 
Embora haja muitos argumentos a favor dessa ênfase, a escola não vai recuperar o ensino da língua estrangeira, "deslocado para os cursos de línguas", como está explicitado nos próprios parâmetros, devido justamente à ênfase na leitura. Muito breve o aluno provavelmente perceberá que para "falar" uma língua estrangeira, só frequentando um "curso de línguas".

Nos dias atuais, com a globalização e os avanços tecnológicos, falar uma língua estrangeira tornou-se essencial. Como visto no decorrer deste capítulo, aprender uma língua estrangeira é uma prática bem antiga no mundo e no Brasil, seja por motivos econômicos, comerciais, diplomáticos, sociais. De acordo com Leffa (2016, p. 151):

Com os avanços das telecomunicações, principalmente da internet, as fronteiras geográficas desaparecem e a interação entre membros com interesses diversificados diminui para dar lugar à interação entre membros com interesses comuns, naquilo que podemos chamar de comunidades ocupacionais.

Hoje, no Brasil, há a obrigatoriedade de ensino de língua estrangeira nas escolas, geralmente de língua inglesa, e de língua espanhola no ensino médio - em virtude do vínculo político e econômico com o Mercosul.

A procura por diversas línguas como francês, alemão, italiano, coreano, mandarim e japonês nas escolas de idioma vem crescendo cada vez mais, seja por uma motivação ocupacional ou cultural.

O mundo moderno também faz com que seja possível aprender qualquer idioma por meio da internet, com livros digitais, áudios e vídeos. Muitos também optam por aprender uma nova língua realizando um intercâmbio, assim imergindo totalmente na cultura da língua-alvo.

\subsection{Metodologias}

Como visto no Capítulo 2 deste trabalho, a metodologia tradicional - também conhecida como gramática-tradução - é a primeira e mais antiga metodologia para o ensino de línguas clássicas, como o grego e o latim. O idioma era ensinado por meio de traduções e versões de textos literários da época. Portanto, o enfoque principal na aprendizagem de língua estrangeira era a leitura, fazendo com que os alunos fossem capazes de compreender tais textos.

Conforme Leffa (2016), existem três passos principais para a aprendizagem da língua no método tradicional: memorização de vocabulário, conhecimento das regras (gramática) e exercício de tradução e versão. 
Neste método, pronúncia e entonação pouco importavam, já que o objetivo da aprendizagem de língua estrangeira se resumia somente à leitura, deixando a comunicação oral de lado. Larsen-Freeman (2000, p. 11 apud JALIL; PROCAILO, 2009, p. 776) aponta:

Este método carregava consigo o princípio de que o exercício de aprender
uma língua estrangeira era benéfico para o aprendiz da língua, mesmo que
nunca chegue a usá-la na oralidade. Assim, a habilidade de se comunicar
por meio da fala não era um dos objetivos deste método, pois o enfoque
estava no desenvolvimento das habilidades de leitura e produção textual.

Assim, a relação professor-aluno era vertical, ou seja, o professor era visto como autoridade e figura que detinha o saber. $O$ aluno era visto como um mero aprendiz que realiza as atividades propostas, sendo corrigido sempre que necessário.

Por volta do século XVI, em oposição à metodologia tradicional, surgiu a metodologia direta, eliminando totalmente o uso da língua materna e focando no uso da língua-alvo dentro de sala de aula.

A leitura continuou sendo um dos alvos principais, mas a fala também ganhou grande destaque. Assim, o professor fazia uso de instrumentos como imagens, simulações e gestos, a fim de facilitar a compreensão dos alunos sem utilizar a tradução.

Diferentemente da metodologia tradicional, que ensinava as estruturas gramaticais de forma dedutiva, a metodologia direta usava uma abordagem indutiva, ou seja, o professor expunha os elementos gramaticais aos alunos para que, mais tarde, eles mesmos chegassem a uma conclusão sobre o sistema linguístico, durante ou após a prática.

Embora o aluno tivesse um papel mais ativo nesta metodologia, o professor ainda era visto como figura principal e detentora de conhecimento. Conforme Cestaro (2004), o professor servia como modelo linguístico ao aprendiz e não havia interação entre os alunos, porém eles podiam se comunicar através de jogos de perguntas e respostas.

Durante a Segunda Guerra Mundial, surgiu uma nova metodologia chamada de metodologia audiolingual. Essa metodologia emergiu a partir da necessidade do exército americano de falantes de diversos idiomas em um curto período de tempo; portanto, a ênfase dessa abordagem era na fala. Segundo Leffa (2016), linguistas e 
informantes foram contratados, as turmas foram reduzidas e a programação consistia em nove horas diárias pelo período de seis a nove meses.

Nesta metodologia, os princípios da psicologia da aprendizagem eram abordados, sendo eles o behaviorismo de Skinner e a linguística distribucional de Bloomfield, já influentes nos Estados Unidos. Portanto, acreditava-se que a aprendizagem de LE, assim como a aquisição de língua materna, se dava a partir de um conjunto de hábitos que deveriam ser repetidos, assim gerando um mecanismo de estímulo-resposta.

Dessa forma, os alunos eram ensinados por meio de exercícios estruturais que consistiam em apresentar a gramática por meio de exemplos e modelos, e o vocabulário por meio de frases completas já prontas.

Anos mais tarde, houve uma decepção em relação a esse método. Conforme Cestaro (2004), os exercícios estruturais irritavam os alunos, assim fazendo com que se sentissem desmotivados. À vista disso, essa foi uma das grandes críticas em relação à metodologia audiolingual, já que os alunos pareciam não conseguir chegar a estágios mais avançados em virtude da dificuldade de passar do automatismo para a espontaneidade da língua.

O humanismo e o cognitivismo da psicologia atual rejeitam a ideia de que a aprendizagem humana pode ser feita de forma automática. Segundo Lakoff (1972, p. 60 apud LEFFA, 2016, p. 32-33):

\begin{abstract}
Até recentemente (início da década de 70), considerava-se uma heresia sugerir que seres humanos eram de algum modo interessante diferente de ratos. Acreditava-se que uma pessoa aprendia uma língua, tanto a primeira como a segunda, como ela e os ratos aprendiam qualquer outra coisa: através da repetição, do exercício e da assimilação de coisas novas sobre uma estrutura antiga já aprendida. [...] Achava-se que era perigoso deixar uma pessoa pensar sobre as frases que elas estavam aprendendo.
\end{abstract}

Portanto, por volta da década de 1980, linguistas europeus passaram a enfatizar o estudo do discurso, pois perceberam que os alunos conseguiam produzir frases corretas gramaticalmente, porém pouco utilizadas no contexto real, fora de sala de aula.

Hymes (1990) desenvolveu, então, o conceito da metodologia comunicativa. O conceito foca na aprendizagem de língua estrangeira por meio da comunicação, fazendo o aluno desenvolver uma competência comunicativa.

Essa metodologia tem como base a noção de competência e performance de Chomsky, ou seja, ou alunos devem ser capazes de produzir enunciados 
linguísticos, a fim de se comunicar de acordo com a situação de comunicação (status, escala social). Dessa forma, conclui-se que o aluno deve possuir um saber linguístico e um saber sociolinguístico. Os exercícios que antes eram formais e repetitivos dão lugar a exercícios interativos de comunicação real ou simulada, fazendo com o que o contexto social e social ganhe mais importância.

$\mathrm{Na}$ metodologia comunicativa, o professor deixa de exercer o papel de figura principal, dono do saber. Ele passa a ser o facilitador, o orientador, inspirando confiança e respeito para compartilhar seu conhecimento.

Segundo Brown (2001 apud JALIL; PROCAILO, 2009, p. 779), o professor promove situações efetivas e reais com o uso da língua, atuando como um conselheiro e encorajando a comunicação entre os alunos por meio de atividades, jogos e dramatizações. Assim sendo, a relação aluno-aluno torna-se tão importante quanto a relação professor-aluno. 


\section{APRENDIZAGEM DE LÍNGUA ESTRANGEIRA}

De acordo com McLaughlin (1978), a aprendizagem de língua estrangeira se refere ao processo de aprendizagem formal, ou seja, o aluno está num ambiente artificial, criado especificamente com o propósito de aprender: a sala de aula.

Neste ambiente, o aluno aprende de modo consciente, ou seja, ele sabe que tem um objetivo a alcançar naquele espaço, onde ele é exposto a regras e à gramática de uma língua estrangeira constantemente. Este processo de aprendizagem de língua estrangeira difere-se do processo de aquisição de língua estrangeira, porém muitas vezes há confusão entre ambos os termos.

A aquisição de língua estrangeira acontece quando o indivíduo está inserido na comunidade da língua-alvo, onde ele está exposto à cultura do país e tem a oportunidade de interagir constantemente com os nativos. Portanto, esse processo se dá num ambiente informal e acontece de forma natural, à medida em que o indivíduo interage e se adapta ao meio.

Leffa (2016, p. 258) afirma:

Se na língua materna predomina o léxico das operações concretas da infância, ligado ao afeto e à família, na língua estrangeira predomina o léxico das operações abstratas da adolescência e da idade adulta, ligado à escola e às disciplinas de estudo.

Além de existir uma distinção prática, existe também uma distinção biológica que explica a diferença entre a aquisição de língua estrangeira e a aprendizagem de língua estrangeira. Biologicamente falando, o ser humano estimula diferentes lados do cérebro para receber cada um desses processos. Balboni $(1998$, p. 16) esclarece:

[...] a aquisição é um processo inconsciente que utiliza estratégias globais do hemisfério direito do cérebro junto com as analíticas do hemisfério esquerdo; a aquisição da linguagem faz parte estável da competência da pessoa, entra na sua memória a longo prazo. Já a aprendizagem é um processo racional, governado pelo hemisfério esquerdo e baseada na memória a médio prazo. A competência agregada é uma competência incompleta, indefinida e é ativada, de modo lento e permanente, pela competência adquirida.

Muitas são as teorias e as abordagens acerca da aquisição linguagem, desde o behaviorismo de Bloomfield e Skinner, o gerativismo de Chomsky, até o interacionismo dos grandes psicólogos Piaget, Wallon e Vygotsky.

Em relação a estes últimos, muitos estudiosos apontam as semelhanças da aquisição de LE e da aprendizagem de LE em relação ao interacionismo. Acredita- 
se que tanto a aquisição quanto a aprendizagem são processos que se dão a partir da interação do indivíduo com o meio sociocultural. Neste aspecto, estar exposto somente ao input linguístico não é suficiente. Schlatter e Garcez (2012, p. 14) apontam que "a aprendizagem acontece na interação com o outro e em vivências significativas com o conhecimento".

Outra semelhança entre ambos os processos de aquisição e aprendizagem de língua estrangeira, segundo a tradição, é a importância do foco no vocabulário. Leffa (2016, p. 261) explica da seguinte da seguinte forma:

\begin{abstract}
A tradição, tanto no ensino de línguas estrangeiras como da língua materna, tem destacado a importância do vocabulário através de inúmeras atividades pedagógicas, desde as listas de palavras descontextualizadas a serem decoradas pelos aprendizes até atividades mais significativas como jogos do tipo forca, bingo, caça-palavra, memória, palavras cruzadas, etc.
\end{abstract}

O autor ainda aponta que o ensino do vocabulário, tanto na aprendizagem quanto na aquisição de LE, oscila entre interno e externo.

De um lado, o aspecto externo foca no input, ou seja, como o professor vai preparar sua aula e oferecê-la ao aluno, a fim de que este internalize seu input, assim ampliando seu conhecimento em relação à língua estrangeira. Por outro lado, o aspecto interno foca em como o aluno faz para adquirir e ampliar esse conhecimento, dessa forma, fazendo com que o professor mire nas diferentes estratégias e estilos de aprendizagem.

Leffa (2016) ainda faz uma distinção entre aprendizagem incidental e aprendizagem intencional. A primeira tem a ver com a aquisição de linguagem, já que é uma aquisição natural, não planejada e contextualizada. O indivíduo recebe o input oral contextualizado, visto que está inserido na comunidade da língua-alvo, assim ampliando seu léxico de forma excepcional. Leffa afirma (2016, p. 280):

O aprendiz da língua não está preocupado em aprender palavras novas, mas em construir um significado do que ouve. É só mais tarde, com a escolarização, que se inicia o processo formal de aprendizagem intencional do léxico, com o esforço deliberado e consciente em aprender palavras novas.

Contudo, o autor deixa claro que essa aprendizagem não é totalmente incidental, visto que, para haver sucesso, outros fatores precisam ser levados em consideração, como atenção, estratégias de aprendizagem e dedução.

Em contrapartida, a aprendizagem intencional, que tem a ver com a aprendizagem de LE, se dá num ambiente formal e planejado. O aluno tem consciência de sua aprendizagem, porém assim como na aprendizagem incidental, 
apenas o input e o material apresentado pelo professor não são suficientes para sua competência linguística.

$\mathrm{Na}$ verdade, por ser um processo planejado, a aprendizagem intencional sofre muito mais implicações, pois vários fatores devem ser ponderados, como é o caso das motivações e dos bloqueios enfrentados pelos alunos.

\subsection{Motivações}

Existem inúmeras razões pelas quais um indivíduo pode se sentir motivado a aprender uma língua estrangeira. Ellis (1994) as classifica como motivação instrumental, motivação integrada, motivação resultativa e motivação intrínseca.

A motivação instrumental tem a ver com a busca da ascensão profissional e educacional do indivíduo, ou seja, ele pode estar à procura de passar em exames, conseguir uma melhor oportunidade de emprego, conseguir uma vaga em um concurso ou em uma universidade.

A motivação integrada tem a ver com a busca não só da aprendizagem da língua estrangeira em si, mas também há um interesse em ter conhecimento sobre a cultura e estilo de vida dos falantes nativos da língua-alvo.

A motivação resultativa, como o nome já sugere, tem a ver com a busca do aluno por bons resultados e desempenhos, assim impulsionando-o a aprender ainda mais. Ou seja, caso ele já tenha aprendido uma língua estrangeira antes e tenha obtido um bom resultado, sua motivação surge a partir do sucesso da experiência anterior.

Por fim, a motivação intrínseca é o interesse e o desejo natural do ser humano de se comunicar e de se relacionar com o meio, assim atraindo-se pela língua estrangeira como campo de estudo ou profissional.

Em relação à motivação intrínseca, Costa e Souza (2003, p. 13) afirmam:

\footnotetext{
Existem alunos que buscam aprender uma segunda língua pelo prazer de aprender, pela satisfação interior que tiram desta atividade. Podemos afirmar então que existe um certo número de pessoas que sentem uma satisfação real no estudo em geral e, portanto, também no estudo de línguas.
}

Gardner e Lambert (1959) foram um dos pioneiros nos estudos que dizem respeito à motivação na aprendizagem de segunda de língua e de língua estrangeira, fazendo uma distinção entre motivação integrada e motivação 
instrumental. Para eles, os indivíduos que têm uma motivação integrada são mais propensos a obter sucesso na aprendizagem de LE, já que o interesse pela língua, pela cultura e pelas tradições surge de forma natural.

Por outro lado, os indivíduos com uma motivação meramente instrumental têm mais chances de se frustrar enquanto aprendendo uma língua estrangeira, visto que estes têm um objetivo maior a ser alcançado.

Contudo, para Brown (1987 apud BAGHIN, 1993), a motivação seria o termo mais completo para explicar o sucesso ou o fracasso numa tarefa complexa, no caso, a aprendizagem de língua estrangeira.

Além das motivações intrínsecas, internas, as motivações externas também têm grande influência no sucesso ou no fracasso da aprendizagem de LE. Enquanto a primeira tem a ver com o interesse, o desejo e a autoconfiança do aluno, a última depende de fatores como a afetividade, a interação, e as questões socioculturais do meio em que se vive.

Conforme Costa e Souza (2003, p. 5), ambas as motivações estão interligadas de certa forma:

A motivação ocorre internamente, mas ela somente vem a acontecer através de uma atuação externa que ao utilizar meios auxiliares, recursos e procedimentos adequados, proporciona ao aluno interesse de estudo e conhecimento.

Ainda segundo Costa e Souza (2003, p. 5), a relação entre a aprendizagem e a motivação é reforçada por meio das seguintes questões:

- $\quad$ Não existe aprendizagem sem motivação;

- Os motivos para se aprender geram novos motivos;

- $\quad$ O sucesso na aprendizagem fortalece a motivação;

- A fim de aprender, a motivação é necessária, mas não é suficiente.

Assim, torna-se evidente que existem diversos fatores que contribuem para o sucesso ou o fracasso da aprendizagem dos alunos. Portanto, faz-se necessário apontar a importância da relação professor-aluno para o incentivo da motivação.

Dentro de sala de aula, o professor não tem só o papel de transmitir seu conhecimento, mas também de incentivar, motivar e impulsionar o desejo dos alunos de aprender. Segundo Medley (1992 apud BAGHIN, 1993, p. 47), "a motivação é uma questão de atitude, atitude do professor", assim, reforçando que os professores devem servir de inspiração para a aprendizagem de seus alunos. 
Por outro lado, Sanchez Perez (1982 apud BAGHIN, 1993, p. 46) aponta alguns aspectos que podem influenciar a motivação dos alunos de maneira negativa, como problemas familiares e pessoais, condição social e idade.

Neste aspecto, pode-se perceber que os alunos recebem diversas influências internas e externas que acabam se inter-relacionando, assim contribuindo para a motivação ou desmotivação da aprendizagem de língua estrangeira.

\subsection{Bloqueios}

Segundo Bogaards (1988), apesar da motivação, da inteligência e de esforços em relação à aprendizagem, muito alunos adultos - faixa etária em foco no presente trabalho - não conseguem dominar a língua estrangeira de forma satisfatória e tampouco desenvolver a competência de comunicação esperada.

Dessa forma, embora haja capacidade cognitiva e motivação para a aprendizagem de língua estrangeira, fatores extralinguísticos podem implicar na aquisição/aprendizagem de um novo idioma. Entretanto, na maioria das vezes, esses fatores não são levados em consideração pelas escolas e instituições de ensino de línguas. Brun (2003) afirma:

[...] O sistema escolar, de maneira geral, não consegue praticar o ideal
humanista que advoga, e a escola raramente leva em consideração os
valores, os sentimentos, as percepções, as atitudes e qualquer outra
categoria de conduta associada à subjetividade humana. Contudo, esta
afetividade é continuamente expressa, por palavras ou por
comportamentos, tornando-se assim inevitável observar que fatores
extralinguísticos representam verdadeiros obstáculos para os alunos e,
particularmente, para os adultos.

Portanto, evidencia-se que a questão afetiva e emocional pode representar um papel de motivação, mas também pode ser um fator que influencia o aluno de forma negativa, envolvendo outras variáveis como autoestima e ansiedade.

Para Lazarus (2000), os indivíduos têm uma tendência de julgar as novas experiências e criar expectativas conforme as sensações em relação à aprendizagem de LE surgem. Essas sensações estão intrinsicamente ligadas às experiências prévias de ensino/aprendizagem que o aluno vivenciou.

Em um de seus estudos, Brun (2003) constatou que os alunos adultos carregam consigo muitas crenças e suposições acerca do processo de aprendizagem de língua estrangeira e de sua própria capacidade de aprendizagem de modo geral. 
Em relação a crenças e suposições, Lightbown e Spada (2006, p. 59 apud FERNANDES, 2011, p. 5981) esclarecem:

As preferências dos alunos para a aprendizagem, quer devido a seu estilo de aprendizagem ou às suas crenças sobre como as línguas são aprendidas, irão influenciar os tipos de estratégias escolhidas, a fim de aprender um novo conteúdo. Os professores podem usar esta informação para ajudar os alunos a ampliar o seu repertório de estratégias de aprendizagem e, portanto, desenvolver uma maior flexibilidade em suas formas de abordagem para a aprendizagem de línguas.

Assim, cabe ao professor identificar tais crenças e suposições a fim de desmistificá-las, usando novas abordagens e estratégias com esses alunos.

Focando na aprendizagem dos adultos, Alvarez e Bonfim (2008) esclarecem que os adultos enfrentam muitas cobranças, tanto externas quanto internas. Os adultos cobram a si mesmos e também são cobrados pela família, pela sociedade, pelo meio cultural em que estão inseridos, sempre sendo pressionados a ter um bom emprego, um companheiro e uma vida independente. Dessa forma, a autoestima do indivíduo é afetada diretamente, fazendo com que ele tenha uma outra percepção de si mesmo, do mundo a sua volta e, consequentemente, da aprendizagem e de sua capacidade em relação a ela.

Além disso, fatores biológicos também devem receber sua devida atenção, pois segundo Fernandes (2011, p. 5982), apoiada nos estudos de Alvarez e Bonfim, "o adulto confronta seus conceitos já formados com estruturas neurais fixas, ou seja, as novas estruturas neurais da língua estrangeira não possuem relação com aquelas já formadas".

Esses bloqueios enfrentados pelos alunos são bastante reforçados pela hipótese do filtro afetivo, desenvolvida por Krashen (1985). Para o autor, o filtro afetivo é um bloqueio mental que impede o aluno de receber o input que ele recebe. Assim, quanto mais baixo o filtro afetivo, mais o aluno está aberto para receber o input. Contudo, quando o filtro afetivo está alto, o aluno é capaz de compreender o que ocorre dentro de sala de aula, mas não é capaz de adquirir o input por completo.

Em relação ao filtro afetivo, Welp (2009, p. 70) aponta:

Isso ocorre quando o aluno está desmotivado, sem autoconfiança, ansioso ou "na defensiva", ou seja, quando vê a aula de língua como lugar onde suas fraquezas serão reveladas. O filtro está "baixo" quando o indivíduo não está preocupado com a possibilidade de falhar na aquisição da língua e quando se considera um membro potencial do grupo falante da língua-alvo.

Nesse sentido, para a autora, a emoção com mais relevância para que o filtro afetivo esteja alto é a ansiedade. Welp (2009) afirma que a ansiedade é um estado 
emocional, portanto ela é dotada de componentes psicológicos e fisiológicos, sendo assim uma das principais causas para impulsionar o desempenho do indivíduo.

Considerando que a ansiedade é um traço comum às emoções humanas e exerce um papel fundamental em relação à motivação e desmotivação dos indivíduos de maneira geral, esta variável afetiva se tornou um importante objeto de estudos tanto na psicologia quanto na educação. 


\title{
4 ANSIEDADE
}

A palavra ansiedade vem do latim anxietas, que significa "apertar", "sufocar". No dicionário on-line, a palavra define-se como "aflição, agonia, angústia, ânsia, nervosismo" e "sentimento e sensação de intranquilidade, medo ou receio". (MICHAELIS, 2020).

O psicólogo existencialista May (1980) aponta que a ansiedade é a apreensão desencadeada por uma ameaça a algum valor que o indivíduo considera de extrema importância para sua vida. Essa ameaça pode ser sentida em relação à vida física, à existência psicológica, à personalidade e a valores. Ele ainda faz uma distinção entre a ansiedade normal e a ansiedade neurótica. Para May, a ansiedade normal é a expressão da capacidade de reagir a ameaças, ou seja, o indivíduo responde à ameaça de uma maneira proporcional e objetiva, visto que este comportamento é inerente ao ser humano, e enfrenta os conflitos de maneira construtiva, tomando-os como experiência.

Já a ansiedade neurótica é caracterizada pela reação desproporcional à ameaça, em que o indivíduo perde a clareza dos fatos e há uma distorção da realidade. Este é o momento em que ocorrem as inibições, o desenvolvimento de sintomas ansiosos e os mecanismos de defesa.

Apesar de ser um sentimento bem desagradável, Pinto (2000) sugere que a resposta ansiosa faz parte do sistema adaptativo de sobrevivência. Essa resposta é um legado evolucionário do ser humano e ela não deve ser subestimada, visto que tem sua importância em diversas situações. Pinto $(2000$, p. 8) ainda acrescenta:

\begin{abstract}
A ansiedade social, ou seja, a ansiedade experimentada em situações sociais, é uma experiência comum nos humanos e está intimamente relacionada com a estrutura social de grupo dos humanos e a sua organização hierárquica. A experiência de graus ligeiros de ansiedade em situações sociais é, assim, um fenômeno frequente num largo número de indivíduos e não impede um funcionamento social adequado podendo, em certos casos, ter até um efeito benéfico do desempenho social.
\end{abstract}

Já Silva (2011), acredita que essa reposta à ameaça ocorre porque o organismo do ser humano é dotado de um mecanismo pré-programado de proteção, conhecido como "reação do medo". Este mecanismo é utilizado pelos indivíduos desde os tempos mais primitivos, crença também apoiada por Klein (1991, p. 86 apud NASCIMENTO; CALSA, 2015, p. 99), que diz que no "início da vida pós-natal, o bebê vivencia ansiedades provenientes de fontes internas e externas [...] A 
primeira fonte externa de ansiedade pode ser encontrada na experiência do nascimento". Isto porque a perda do contato com o útero e a sensação da respiração são desconfortáveis para o recém-nascido que está descobrindo um mundo totalmente novo.

Contudo, fica claro que a ansiedade é um sentimento natural vivenciado por todos os seres humanos em algum momento de suas vidas. Ela faz parte do crescimento e das mudanças enfrentadas ao longo dos anos, da identidade do indivíduo e de sua autopreservação.

Entretanto, quando o nível de ansiedade se intensifica e a resposta à ameaça é exacerbada, causando diversos sintomas e sofrimento, é provável que o indivíduo esteja com algum transtorno de ansiedade. A ansiedade torna-se patológica quando existe a sensação de perigo constante e a expectativa pelo que pode acontecer, provocando uma grande perturbação em quem vivencia esse ciclo e, assim, afetando o funcionamento social do indivíduo, que muitas vezes passa a evitar situações de convívio social. Essa reação é explicada por Pinto $(2000$, p. 8) da seguinte maneira:

Nestes casos, o receio de ser avaliado negativamente, de parecer ridículo, tolo, de não estar à altura da situação e ver o seu estatuto pessoal diminuído desperta graus tão elevados de desconforto e medo, que a vida diária fica severamente limitada.

Silva (2011) explica os transtornos de ansiedade e estabelece uma distinção entre ser ansioso e estar ansioso. Para ela, ser ansioso é um trato que domina os demais aspectos da personalidade do indivíduo, que fica num constante estado de inquietação, tensão e apreensão. Ser ansioso é inerente ao ser que experimenta essa ansiedade. Por outro lado, estar ansioso é ter todas as sensações acima citadas acompanhadas de manifestações orgânicas, como: taquicardia, sudorese, tonturas, náuseas, palpitações e tremores. Estas manifestações orgânicas geralmente aparecem após algum estímulo externo, ou seja, ameaça. Portanto, pode-se concluir que ser ansioso tem a ver com o psíquico, é inerente ao ser; estar ansioso depende de fatores externos e dos estímulos que o indivíduo recebe. Silva (2011, p. 27) esclarece:

Assim, os transtornos de ansiedade correspondem aos estados de ansiedade (estar ansioso) em indivíduos que possuem uma personalidade ansiosa de fundo ou base (ser ansioso). Logo, fisiologicamente pensando, quando o ser se une ao estar em uma personalidade já ansiosa, estados severos de desconforto e sofrimento são gerados. 
Essa dialética começou a ser estudada e foi introduzida por Spielberger (1970), sendo chamada de Ansiedade Traço-Estado. O estudo, que foi denominado como Inventário de Ansiedade Traço-Estado (IDATE), quantifica os componentes relacionados à ansiedade e avalia a ansiedade-traço e a ansiedade-estado numa escala. Para Spielberger, o traço tem a ver com as características estáveis da personalidade, e o estado tem a ver com uma resposta temporária a um estímulo específico. Basicamente, os indivíduos que se sentem ansiosos em diversas situações apresentam uma ansiedade-traço. Já os indivíduos que se sentem ansiosos apenas em situações muito específicas apresentam uma ansiedadeestado.

Independentemente de ser ou estar ansioso, ambas condições trazem extremo desconforto para aqueles que as experimentam. Contudo, estar ansioso depende de situações e estímulos particulares, como visto anteriormente, trazendo diversos sintomas desagradáveis. Sendo assim, a reação mais comum dos indivíduos que se encontram numa situação que os deixa ansiosos é a esquiva. As pessoas que se sentem ameaçadas em situações específicas são propensas a evitar tais situações ou simplesmente desistem de enfrentá-las.

Bauman (2007) acredita que a ansiedade é uma condição da atualidade, tendo em vista que a modernidade líquida está marcada por um estado de ansiedade generalizada, independentemente da idade ou do grupo social.

Silva $(2011$, p. 28) reforça essa ideia de que os transtornos de ansiedade ocorrem cada vez com mais frequência. Ela acrescenta:

\begin{abstract}
Recentes estudos norte-americanos, de abrangência significativa, revelaram que $25 \%$ das pessoas apresentam algum tipo de transtorno de ansiedade ao longo de suas vidas. A primeira reação diante dessa estatística é assustadora; afinal, trocando em miúdos, o que eles evidenciaram é que um quarto da população mundial sofre ou sofrerá algum tipo de transtorno ansioso durante toda a sua existência. Mas, infelizmente, esses dados refletem e atestam a mais absoluta realidade.
\end{abstract}

Sabe-se que a maioria das pessoas que sofre com algum tipo de transtorno de ansiedade não busca ajuda, e que a reação mais comum é a de fuga da realidade. Tendo isso em vista, fica evidente que é de extrema importância que amigos, familiares, professores e pedagogos estejam atentos e dispostos a ajudar aqueles que estão ansiosos. Assim, a próxima Seção (4.1) do presente trabalho irá considerar os aspectos da ansiedade em situação específica, mais precisamente, a ansiedade em sala de aula. 


\subsection{Ansiedade em sala de aula}

A ansiedade é uma consequência natural em situações que parecem ameaçadoras e que estão além da capacidade do indivíduo de lidar com a ameaça. Segundo Guiora (1983), a aprendizagem de línguas estrangeiras pode ameaçar a visão de mundo que o indivíduo construiu ao longo dos anos e a concepção que ele tem de si mesmo. A forma com que os alunos se expressam torna-se limitada por meio da imperfeição do domínio da língua estrangeira. Essa incapacidade de compartilhar a sua autoimagem pode fazer com que o aluno comece a ter uma autoavaliação negativa de si mesmo, conforme apontam Horwitz, Horwitz e Cope (1986). Eles ainda acrescentam que falar uma língua estrangeira pode parecer uma ameaça para a identidade e o ego do indivíduo.

Horwitz et al. (1986) fizeram um estudo e estabeleceram três tipos de ansiedade em sala de aula. A primeira delas é a apreensão comunicativa, que é caracterizada pela ansiedade em se comunicar com outras pessoas de forma geral, ou seja, o aluno pode sentir medo de falar e de não entender o discurso de outras pessoas. Isso acontece porque $o$ indivíduo tem ideias e pensamentos bem estabelecidos, porém não consegue compartilhá-los por não ter domínio total da língua, assim gerando apreensão. $O$ segundo tipo é a ansiedade de teste, que é definida pelo medo ou apreensão de realizar testes/avaliações. Isso acontece porque os alunos costumam se cobrar de forma exagerada e estabelecer altos níveis de exigência para seu desempenho. Os alunos têm medo de falhar.

O terceiro e último componente é o medo da avaliação negativa. Os alunos se sentem constantemente ameaçados em serem julgados de forma negativa quando falam em outro idioma na frente de outros alunos, ou de outras pessoas de modo geral.

Dessa forma, nota-se que a comunicação e a compreensão oral são as causadoras de maior desconforto dentro e fora de sala de aula, visto que são as atividades em que os alunos mais se expõem e ficam vulneráveis. Welp (2009, p. 75) define a comunicação em LE da seguinte maneira: 
[...] A comunicação oral - seja através da produção como da compreensão - torna-se problemática na língua estrangeira em razão da imaturidade de domínio da língua-alvo, comparando-se com a proficiência na língua materna. A autocrítica do aprendiz adulto em relação ao seu desempenho diante de outros pode ser ameaçada por suas limitações na língua estrangeira, tanto no que diz respeito ao vocabulário quanto à estrutura linguística.

Por outro lado, Young (1991) aponta as causas e os efeitos da ansiedade linguística e os atribui a seis fatores. A sua pesquisa se baseia em três componentes da aprendizagem: o próprio aprendiz, ou seja, o aluno; o professor e a prática utilizada. Os seis fatores mencionados são:

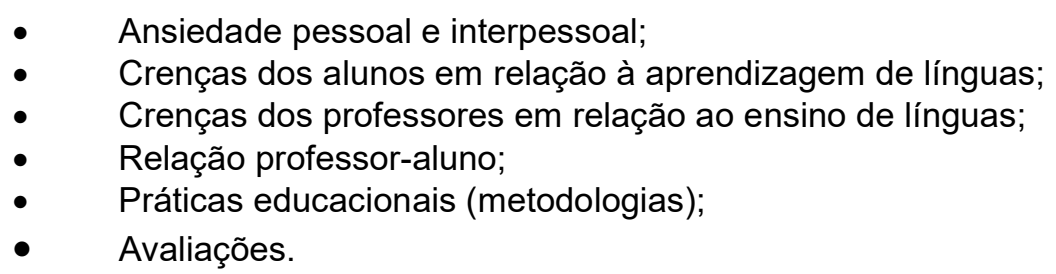

Acredita-se que a ansiedade dentro de sala de aula também possa impactar o desempenho dos próprios professores de forma negativa ao apresentar algum tipo de conteúdo. Embora todos esses seis fatores sejam de extrema importância e estejam interrelacionados, para o presente trabalho, quatro deles serão examinados mais a fundo: a ansiedade pessoal e interpessoal, que tem a ver com a autoimagem do aprendiz; as crenças dos alunos; as crenças dos professores, que trazem consequências diretas à/ao aprendizagem/ensino; e, por fim, a relação professoraluno, que tem seus efeitos não só na aprendizagem, mas também no convívio e no espaço educacional.

É sabido que o ambiente escolar deve ser um local que traga conforto e segurança para o aluno, onde ele possa aprender e absorver as informações compartilhadas. No entanto, a sala de aula pode ser o ambiente que provoca a inibição do aluno, como já foi constatado no segundo parágrafo deste trabalho. Vale ressaltar que, embora o foco do presente trabalho não seja o público infantil, a educação parental também contribui para o comportamento do indivíduo em sala de aula. De acordo com Pinheiro (2009), uma educação demasiadamente protetora ou crítica pode fazer com que o aluno não tenha uma boa autoimagem, e isso pode se perpetuar pela vida adulta. Além disso, o aluno - criança ou adulto - que não se mostra ansioso em relação a nenhum tipo de atividade escolar pode-se tornar desmotivado, o que também contribui de forma negativa para sua aprendizagem. 
Cabe à escola identificar os diferentes tipos de alunos e se adaptar às necessidades de cada um.

A Prática Exploratória é uma área que enfatiza que a qualidade de vida dentro e fora da sala de aula são extremamente importantes para a aprendizagem do aluno. A qualidade de vida está intimamente ligada ao desenvolvimento do ser em diversos contextos. Allwright (2006, p. 14 apud SILVEIRA, 2012, p. 34) afirma:

\begin{abstract}
A qualidade de vida é, por si só, o que mais importa, tanto para a saúde mental da humanidade a longo prazo (e a saúde mental dos professores de línguas), quanto para encorajar as pessoas a serem eternas aprendizes, em vez de serem pessoas que se ressentem por terem de passar anos das suas vidas como aprendizes "em cativeiro", e consequentemente adiam o aprendizado para o resto da vida.
\end{abstract}

É importante pontuar que o ambiente dentro de sala de aula tem como participantes alunos e professores. Portanto, a boa relação professor-aluno é essencial para que esse espaço seja acolhedor, seguro e traga o sentimento de qualidade de vida para todos.

\title{
4.2 Afetividade e ansiedade
}

Ribeiro (2004) cita o currículo de ensino de acordo com os Parâmetros Curriculares Nacionais - PCN (BRASIL, 1997) e afirma que a orientação oficial estabelece que o educador tenha um desenvolvimento que vai além do ensino teórico de uma disciplina. Essa orientação certifica um desenvolvimento no âmbito da afetividade dos educadores em relação aos alunos.

Quando os alunos se deparam com um professor que mantém um bom relacionamento com eles, o interesse pela aula ou pela disciplina aumenta, assim como a motivação e a participação dentro de sala de aula.

Tassoni (2012) conduziu uma pesquisa sobre afetividade com três turmas na faixa de seis anos de idade e chegou à conclusão de que houve uma redução do estresse desses alunos quando os professores se comprometiam a combater 0 excesso de ansiedade durante as atividades propostas, buscando tranquilizá-los e encorajá-los na realização delas. Tassoni (2012, p. 15 apud MORAIS, 2018 p. 3233) garante que a conduta dos professores foi primordial na aprendizagem desses alunos: 
Medo, angústia, ansiedade e frustração são sentimentos que desgastam o aluno. A serenidade e a tranquilidade das professoras auxiliaram na redução ou até na eliminação desses sentimentos desagregadores, permitindo o que Dantas (1994) denomina de "destravamento" da afetividade cognitiva.

Muitas vezes, os professores podem ser intolerantes com certos tipos de comportamentos dos jovens e dos adultos, porém tais comportamentos podem ser projeções da personalidade do próprio educador. Portanto, é papel do professor identificar esta conduta e não deixar que isso influencie de alguma forma o seu relacionamento com os alunos.

Conforme Andersen (2009 apud PINHEIRO, 2009 p. 163), os comportamentos que influenciam para com a baixa autoestima dos alunos devem ser eliminados. São eles: agressividade, discriminação, intrigas e formação de grupos fechados.

Apoiando-se na teoria vygotskiana, Leite (2012, p. 365) diz o seguinte:

É possível defender que a afetividade está presente em todas as decisões assumidas pelo professor em sala de aula, produzindo continuamente impactos positivos ou negativos na subjetividade dos alunos. Trata-se, pois, de um fator fundante nas relações que se estabelecem entre os alunos e os conteúdos escolares. A qualidade da mediação pedagógica, portanto, é um dos principais determinantes da qualidade dos vínculos que se estabelecerão entre os sujeitos/alunos e os objetos/conteúdos escolares.

Pode-se perceber que, na maioria das vezes, o termo "afetividade" é associado somente ao lado positivo, como o carinho, o cuidado e a atenção, porém, como visto acima, o professor pode produzir tanto impactos positivos quanto negativos. A afetividade está intrinsicamente ligada aos fenômenos psíquicos que se revelam através das emoções e dos sentimentos, sejam eles bons ou ruins. Dessa forma, a compreensão da afetividade é de extrema importância para os educadores, para as escolas e, também, para os pais nos primeiros anos de vida das crianças.

Existe uma grande necessidade de que os professores tomem consciência e reconheçam os aspectos afetivos do ensino-aprendizagem, pois, conforme afirma Piaget (2014 apud MORAIS, 2018, p. 45), não existe o estado afetivo sem o aspecto cognitivo, eles coexistem:

Num primeiro sentido, poderíamos dizer que a afetividade interfere nas operações da inteligência, que ela as estimula ou as perturba, que é a causa de acelerações ou retardos no desenvolvimento intelectual, mas que não pode modificar as estruturas da inteligência como tais. [...] Esse papel da afetividade como acelerador ou perturbador das operações da inteligência é incontestável. $\mathrm{O}$ aluno motivado em aula terá mais entusiasmo para estudar e aprenderá mais facilmente. 
Partindo do proposto por Piaget (2014), a afetividade torna-se fonte de conhecimento, já que afeto e cognitivo estão interligados. Quando o aluno utiliza a inteligência (aspecto cognitivo) para resolver qualquer questão em uma atividade, ele automaticamente utiliza o aspecto afetivo, ou seja, suas emoções, já que se cria uma expectativa por parte do aluno para realizar a atividade.

A crença que os professores têm em relação ao papel deles no ensino de língua estrangeira também tem um grande impacto na afetividade formada com os alunos. Por meio de seus estudos, Young (1991) notou que alguns professores acreditavam que o papel do professor seria semelhante ao de um "instrutor militar" em vez de "facilitador; mediador" e que existe a necessidade de corrigir o erro dos alunos de forma constante. Isso reforça ainda mais a ideia de que a interação entre os professores e os aprendizes tem uma função no aumento ou na diminuição dos níveis de ansiedade dos estudantes.

Segundo Bekleyen (2004), quando o professor corrige os alunos, o problema para o aluno não está na correção em si, mas na maneira com a qual ele foi corrigido. Em que momento, com qual frequência, e quantos erros foram corrigidos também fazem diferença para eles. Essa afirmação é reforçada com um estudo feito em uma escola japonesa, onde Aida (1994 apud BEKLEYEN, 2004, p. 50) pesquisou sobre os efeitos da personalidade dos professores e suas metodologias. Com seu estudo, foi descoberto que o modo severo com que os professores davam aula criou um ambiente de terror e desconforto, levando os alunos a se sentirem ansiosos e a ficarem com medo.

Bekleyen (2004) conduziu seu estudo sobre a influência dos professores e colegas de classe na ansiedade de língua estrangeira e constatou que os alunos entrevistados geralmente avaliavam os professores através de suas personalidades. A maioria dos alunos se sentia mais confortável nas aulas em que os professores se mostravam mais gentis e dinâmicos. A crença dos alunos em relação ao professor é de que seu papel principal é oferecer uma atmosfera confortável.

Com isso, conclui-se que as crenças dos alunos e dos professores divergem em relação ao ensino de LE. Os alunos desejam um ambiente relaxado com professores gentis e pacientes e, por outro lado, muitos professores acreditam que devem ser rigorosos e exigentes. A falta de comunicação e compreensão entre professor-aluno faz com que a sala de aula se torne um ambiente cheio de medos, receios, apreensão e desmotivação. Ambas as partes precisam ser estimuladas e se 
sentirem confortáveis no ambiente em que passarão horas, meses ou anos de suas vidas. Cabe ao professor se reeducar em relação às próprias crenças para que, dessa forma, ele também possa reduzir as crenças negativas que os alunos têm sobre os professores, a sala de aula e a aprendizagem de LE.

\subsection{Crenças e ansiedade}

O conceito de crenças na aprendizagem de língua estrangeira começou a ser estudado no exterior nos anos 1980 e em meados dos anos 1990 no Brasil. Esses estudos surgiram dentro da área de Linguística Aplicada, com o desejo de mudar o enfoque do produto, ou seja, a linguagem para o enfoque do processo. No exterior, Horwitz (1985) foi a pioneira dos estudos sobre crenças na aprendizagem de LE, criando um sistema chamado BALLI (Beliefs About Language Learning Inventory) a fim de investigar as crenças de alunos e professores. Esse sistema avalia 34 itens divididos entre cinco categorias, são elas:

- $\quad$ dificuldade de aprender uma LE;

- $\quad$ aptidão para aprender uma LE;

- $\quad$ natureza do aprendizado de línguas;

- relação entre aprendizado e estratégias comunicativas;

- motivação e expectativas.

A partir desse estudo, Horwitz (1985) concluiu que, embora os alunos tenham consciência de que aprender uma nova língua demanda tempo, eles acreditam que a aprendizagem de LE seja difícil. Muitos desses alunos mostraram ter expectativas irreais em relação à aprendizagem de língua estrangeira, não mostravam interesse pela cultura da língua-alvo e não acreditavam que aprender uma língua estrangeira traria algum tipo de benefício profissional futuramente. Contudo, os alunos de LE como segunda língua (SL) tinham interesse pela cultura estrangeira e acreditavam ser mais fácil aprender no país de origem da língua-alvo.

Assim, o estudo foi concluído mostrando que os diferentes aspectos sociais e culturais, e as experiências individuais têm uma grande influência nas crenças sobre aprendizagem de LE, levando os aprendizes a se sentirem ansiosos em relação às suas expectativas.

Breen (1985, p. 136 apud BARCELOS, 2004, p. 125) diz que "nenhuma instituição ou relacionamento humano pode ser adequadamente entendido, a menos que consideremos as suas expectativas, valores e crenças". 
De acordo com Izard e Smith (1982, apud SILVEIRA, 2012, p. 62), as crenças têm uma natureza paradoxal visto que surgem do verbo "crer", que tanto pode significar uma dúvida ou uma certeza. Elas podem ser utilizadas para fundamentar, reprovar, pressupor. As crenças, de modo geral, fazem parte das culturas e tradições milenares de diferentes povos.

Já nos estudos conduzidos por Ellis (1994), ele aponta que as crenças em relação à aprendizagem têm um caráter individual, ou seja, cada aluno é passível de ter a sua própria crença e que elas são capazes de influenciar o processo de aprendizagem.

No Brasil, Barcelos (1995, p. 40) foi uma das precursoras dos estudos de crenças na aprendizagem de língua estrangeira e ela as conceitua da seguinte maneira:

Conhecimento intuitivo implícito (ou explícito) dos aprendizes constituído de crenças, mitos, pressupostos culturais e ideias sobre como aprender línguas. Esse conhecimento compatível com sua idade e nível socioeconômico é baseado na sua experiência educacional anterior, leituras prévias e contatos com pessoas influentes.

Por outro lado, Cortazzi e Jin (1996, p. 230 apud BARCELOS, 2004, p. 131) denotam as crenças como:

Os aspectos culturais sobre ensino e aprendizagem; o que as pessoas acreditam sobre atividades e processos "normais" e "bons" de aprendizagem, onde tais crenças têm origem cultural.

Dessa forma, pode-se concluir que as crenças sobre a aprendizagem de LE estão muito mais além do processo cognitivo em si e do que se aprende em sala de aula. Essas crenças têm uma forte base cultural e social, visto que as experiências, as interpretações, as interações com o meio e, principalmente, a visão de mundo influenciam a vida do aluno num aspecto global e, também, na aprendizagem de línguas estrangeiras.

As crenças em relação à LE afetam diretamente $O$ processo de aprendizagem, pois elas influenciam as expectativas e as motivações dos alunos. Muito se especula acerca do processo de aquisição de segunda língua, das metodologias utilizadas pelas instituições ou pelos professores e da idade "correta" para se aprender um novo idioma.

Almeida Filho (1993) acredita que a metodologia utilizada pelos professores e a forma com que os alunos aprendem podem ser incompatíveis, levando à desistência e à dificuldade de aprendizagem e ensino de línguas estrangeiras. Para 
ele, existem possíveis discrepâncias no que diz respeito às expectativas dos alunos em relação ao ensino e às expectativas dos professores em relação aos alunos. As crenças e as expectativas de ambas as partes constituem um grande papel na ansiedade em sala de aula de língua estrangeira. Essas afirmações reforçam ainda mais o papel da afetividade professor-aluno, conforme citado na Seção 4.2 do presente trabalho.

Dessa forma, faz-se necessário buscar entender quais são as crenças de quem ensina e de quem aprende, já que a relação destes é de extrema importância. Para Johnson (1994), a crença dos professores é resultado da imagem que eles têm da experiência de aprendizagem, uma vez que já foram alunos, e da imagem deles mesmos como a figura que compartilha conhecimento. Muitas vezes, os professores tomam seus antigos professores de ensino superior como modelo para aplicar suas práticas institucionais.

A fim de tentar mudar essas crenças, Félix (1999 apud PAGOTO, 2009, p. 6) esclarece:

Seria desejável que os professores tivessem conhecimento e desenvolvessem suas competências, o que significa estar em constante processo de formação a partir de uma tomada de consciência dos seus conhecimentos implícitos para que se tornem profissionais mais críticos e autônomos.

Contudo, ela acrescenta que nem sempre seria possível dar continuidade ao processo de formação por questões financeiras, falta de tempo ou até mesmo pela falta de informação acerca do assunto.

Em relação às crenças dos aprendizes, Young (1991) diz que elas são um dos principais fatores que contribuem para a ansiedade em sala de aula de língua estrangeira. A maioria dos alunos acredita não ter aptidão suficiente para se comunicar e, muitos deles evitam cometer erros a fim de preservar suas faces, principalmente os alunos adultos.

Gardner (1988 apud SILVEIRA, 2012, p. 69) verificou que, mesmo com resultados positivos ou parecidos com o dos demais colegas, muitos alunos acreditavam ter um desempenho ruim e sentiam que não estavam aprendendo, levando-os a se sentir ansiosos e, muitas vezes, a desistir dos estudos de língua estrangeira.

Deste modo, torna-se evidente que há uma necessidade de que os professores estejam preparados para lidar com as várias crenças encontradas em 
sala de aulas, e que essas crenças possam divergir com as suas próprias. Como visto na Seção 4.2 deste trabalho, o professor deve assumir o posto de facilitador não só da aprendizagem de língua estrangeira, mas da aprendizagem em geral. É de extrema importância estabelecer um ambiente confortável e de confiança para diminuir ao máximo as crenças negativas, as falsas expectativas e, principalmente, a ansiedade, fazendo com que a aprendizagem de língua estrangeira seja um momento prazeroso de troca de conhecimento e experiências para o aluno e o professor. 


\section{ANSIEDADE LINGUÍSTICA EM AULAS DE INGLÊS E FRANCÊS COMO LÍNGUA ESTRANGEIRA}

Conforme mencionado na Seção 4.1 deste trabalho, aprender uma nova língua envolve não só a capacidade cognitiva dos aprendizes, mas também as emoções. Quando essas emoções são negativas, incluindo o medo, a ansiedade, o nervosismo e o estresse, a aprendizagem pode sofrer um grande impacto.

Apesar de a ansiedade ser uma resposta natural do ser humano a situações que apresentam risco, quando vivida de forma intensa, de um modo que atrapalha a vida do aluno, ela deve ser investigada e tratada em conjunto com a família e a instituição de ensino para que a aprendizagem e o próprio aluno não sejam prejudicados.

Este capítulo investiga se os professores de línguas inglesa e francesa têm conhecimento da ansiedade gerada dentro da sala de aula, qual é o papel deles frente a essa situação e como eles lidam com isso. Ademais, pesquisa em quais habilidades os alunos de línguas inglesa e francesa se sentem mais vulneráveis e como eles se sentem em relação à sala de aula e a seus professores de modo geral.

\subsection{Contexto}

Foram entregues por e-mail quatro questionários a quatro professores de um mesmo curso de idiomas privado localizado na cidade de Niterói, estado do Rio de Janeiro. Dentre eles, dois são professores de inglês e os outros dois são professores de francês.

É importante ressaltar que, por questões de simplicidade, embora o sexo de alunos e professores tenha sido registrado no presente trabalho, todos os participantes serão identificados no gênero masculino.

No Quadro 1 é possível observar a faixa etária dos professores entrevistados. Dos quatro professores participantes, três estão na faixa de 20 anos a 30 anos, representando $75 \%$ do total de professores respondentes. Apenas um professor está entre 40 anos e 50 anos de idade, assim representando $25 \%$ do total de professores que responderam o questionário. 


\begin{tabular}{|c|c|c|}
\hline Idade (em anos) & Total & $\%$ \\
\hline 20 a 30 & 3 & 75,00 \\
\hline 40 a 50 & 1 & 25,00 \\
\hline Totais & 4 & 100,00 \\
\hline
\end{tabular}

No Quadro 2, nota-se que, do total dos respondentes, dois professores são homens, representando $50 \%$ do total de entrevistados, e dois professores são mulheres, representando os outros $50 \%$ do total de entrevistados.

\begin{tabular}{|}
\begin{tabular}{|c|c|c|}
\hline Sexo & Total & $\%$ \\
\hline $\mathbf{M}$ & 2 & 50,00 \\
\hline $\mathbf{F}$ & 2 & 50,00 \\
\hline Totais & 4 & 100,00 \\
\hline
\end{tabular} \\
Quadro 2 - Sexo dos professores
\end{tabular}

No Quadro 3, verifica-se que, do total de professores entrevistados, cada um deles tem uma formação diferente. Sendo assim, um professor se formou em um curso de idiomas no exterior, representando $25 \%$ do total; um professor se formou em um curso de idiomas no Brasil, representando $25 \%$ do total; um professor tem curso superior, representando $25 \%$ do total; e por fim, um professor tem mestrado, representando os outros $25 \%$ do total de respondentes.

\begin{tabular}{|c|c|c|}
\hline Formação & Total & $\%$ \\
\hline Curso Exterior & 1 & 25,00 \\
\hline Curso Brasil & 1 & 25,00 \\
\hline Curso Superior & 1 & 25,00 \\
\hline Mestrado & 1 & 25,00 \\
\hline Totais & 4 & 100,00 \\
\hline
\end{tabular}

Observa-se que os professores entrevistados têm diferentes formações e, conforme mencionado na Seção 4.3 deste trabalho, para que educadores possam mudar suas crenças sobre assuntos como a ansiedade, seria interessante dar continuidade às suas formações. Entretanto, para o presente trabalho, as possíveis especializações não foram investigadas. De qualquer forma, este fato não influenciará no resultado final desta pesquisa.

Outros questionários (de conteúdo diferente dos professores) foram entregues a quatro grupos de quatro alunos cada, por e-mail. Estes quatro grupos 
são identificados como cursando francês, cursando inglês, formados em francês e formados em inglês.

Portanto, foram entregues, ao todo, 16 questionários iguais a 16 alunos. Estes alunos pertencem a diferentes cursos de idiomas e é importante ressaltar que os professores entrevistados para o presente trabalho não lecionam para nenhum dos alunos respondentes.

No Quadro 4, verifica-se que seis cursos de idiomas participaram do questionário, sendo três deles cursos privados e os outros três, cursos públicos.

\begin{tabular}{|c|c|}
\hline Cursos & Alunos participantes \\
\hline CFPR & 1 aluno (FF2) \\
\hline CIPR1 & 2 alunos (F14; Cl4) \\
\hline CLEGOV1 & 4 alunos (FI3; FF1; FF3; FF4) \\
\hline CIPR2 & 2 alunos (FI1; FI2) \\
\hline CLEGOV2 & 5 alunos (Cl3; CF1; CF2; CF3; CF4) \\
\hline CLEGOV3 & 2 alunos (Cl2, Cl1) \\
\hline
\end{tabular}

Quadro 4 - Cursos participantes

Para este trabalho, os nomes dos cursos serão preservados, porém, para melhor identificação, eles estão denominados sob forma de sigla. Portanto, alunos dos seguintes cursos foram entrevistados: um curso de francês privado (CFPR), localizado na cidade de São Gonçalo, estado do Rio de Janeiro; dois cursos de inglês privados (CIPR1 e CIPR2), ambos localizados na cidade de São Gonçalo, estado do Rio de Janeiro; um curso de línguas estrangeiras (CLEGOV1) vinculado à prefeitura de São Gonçalo, estado do Rio de Janeiro; um curso de línguas estrangeiras (CLEGOV2) pertencente a uma universidade federal do estado do Rio de Janeiro; e, por fim, um curso de línguas estrangeiras (CLEGOV3) pertencente a uma universidade federal do estado de Santa Catarina.

Com isso, pretende-se verificar como alunos de níveis diferentes, ou seja, os que ainda cursam uma língua estrangeira e os que já são formados em uma língua estrangeira se sentem e se comportam em relação à aprendizagem de língua estrangeira, não só no que tange à ansiedade, mas também de uma maneira geral.

Em relação aos grupos de alunos, a faixa etária dos alunos cursando francês foi registrada no Quadro 5. 
Apenas um aluno está entre 10 anos e 20 anos, assim constituindo $25 \%$ do total de alunos respondentes. Os alunos restantes (três alunos) estão na faixa de 20 anos a 30 anos, constituindo $75 \%$ do total de entrevistados.

\begin{tabular}{|c|c|c|}
\hline Idade (em anos) & Total & $\%$ \\
\hline $\mathbf{1 0}$ a $\mathbf{2 0}$ & 1 & 25,00 \\
\hline $\mathbf{2 0}$ a $\mathbf{3 0}$ & 3 & 75,00 \\
\hline Totais & 4 & 100,00 \\
\hline
\end{tabular}

Quadro 5 - Faixa etária dos alunos cursando francês

Em relação ao sexo dos alunos cursando francês, nota-se no Quadro 6 que um aluno se identifica como homem, representando $25 \%$ do total. Os alunos restantes (três alunos) se identificam como mulheres, representando, dessa forma, $75 \%$ do total dos alunos cursando francês.

\begin{tabular}{|c|c|c|}
\hline Sexo & Total & $\%$ \\
\hline $\mathbf{M}$ & 1 & 25,00 \\
\hline $\mathbf{F}$ & 3 & 75,00 \\
\hline Totais & 4 & 100,00 \\
\hline
\end{tabular}

Quadro 6 - Sexo dos alunos cursando francês

No Quadro 7, verifica-se o nível de francês dos alunos que ainda estão cursando o idioma, segundo o Quadro Comum Europeu de Referência para Línguas (QCER) ${ }^{1}$.

Um aluno está no nível A1, constituindo $25 \%$ do total dos entrevistados; dois alunos estão no nível $\mathrm{A} 2$, constituindo $50 \%$ do total; e o último aluno está no nível B2, constituindo $25 \%$ do total de alunos respondentes.

\footnotetext{
${ }^{1}$ O QCER é um quadro de referências padrão utilizado internacionalmente que mede a proficiência do aluno em um idioma. Existem seis níveis, sendo eles: A1 (iniciante); A2 (básico); B1 (intermediário); B2 (usuário independente); C1 (proficiência operativa eficaz); e C2 (domínio pleno). Para este trabalho, somente os quatro primeiros níveis foram analisados. Os níveis iniciante, intermediário e avançado dos alunos de inglês desta pesquisa foram convertidos para A1, B1 e B2 respectivamente. (BRITISH COUNCIL, 2020).
} 


\begin{tabular}{|c|c|c|}
\hline Nível & Total & $\%$ \\
\hline A1 & 1 & 25,00 \\
\hline A2 & 2 & 50,00 \\
\hline B1 & 0 & 0,00 \\
\hline B2 & 1 & 25,00 \\
\hline Totais & 4 & 100,00 \\
\hline
\end{tabular}

Quadro 7 - Nível dos alunos cursando francês

No que concerne à formação dos alunos cursando francês, é possível observar no Quadro 8 que todos os quatro alunos entrevistados têm o ensino superior incompleto.

\begin{tabular}{|c|c|c|}
\hline Formação & Total & $\%$ \\
\hline SEM & 0 & 0,00 \\
\hline EMI & 0 & 0,00 \\
\hline EMC & 0 & 0,00 \\
\hline SI & 4 & 100,00 \\
\hline SC & 0 & 0,00 \\
\hline PÓS & 0 & 0,00 \\
\hline Totais & 4 & 100,00 \\
\hline
\end{tabular}

Quadro 8 - Formação dos alunos cursando francês ${ }^{2}$

No que diz respeito ao grupo de alunos cursando inglês, o Quadro 9 apresenta a faixa etária destes alunos.

Nota-se que um aluno pertence à faixa dos 10 anos aos 20 anos, representando $25 \%$ do total de alunos interrogados. Os alunos restantes (três) cursando inglês têm entre 20 anos e 30 anos, assim representando $75 \%$ do total de respondentes.

\begin{tabular}{|c|c|c|}
\hline Idade (em anos) & Total & $\%$ \\
\hline $\mathbf{1 0}$ a $\mathbf{2 0}$ & 1 & 25,00 \\
\hline $\mathbf{2 0}$ a $\mathbf{3 0}$ & 3 & 75,00 \\
\hline Totais & 4 & 100,00 \\
\hline
\end{tabular}

Quadro 9 - Faixa etária dos alunos cursando inglês

Como é possível observar no Quadro 10, um participante se identifica como homem $(25 \%)$ e três participantes se identificam como mulheres $(75 \%)$.

\footnotetext{
${ }^{2}$ As siglas referentes à formação dos alunos do Quadro 8 e outros mais à frente representam: SEM (sem ensino médio); EMI (ensino médio incompleto); EMC (ensino médio completo); SI (superior incompleto); SC (superior completo); e PÓS (pós-graduação).
} 


\begin{tabular}{|c|c|c|}
\hline Sexo & Total & $\%$ \\
\hline $\mathbf{M}$ & 1 & 25,00 \\
\hline $\mathbf{F}$ & 3 & 75,00 \\
\hline Totais & 4 & 100,00 \\
\hline
\end{tabular}

Quadro 10 - Sexo dos alunos cursando inglês

Em relação ao nível de inglês dos alunos que participaram do questionário, como mostrado no Quadro 11, conforme o padrão de referência europeu (QCER), três deles estão no nível $\mathrm{A} 1$, representando $75 \%$ do total de respondentes. $\mathrm{O}$ aluno restante encontra-se no nível B2, constituindo $25 \%$ do total.

\begin{tabular}{|c|c|c|}
\hline Nível & Total & $\%$ \\
\hline A1 & 3 & 75,00 \\
\hline A2 & 0 & 0,00 \\
\hline B1 & 0 & 0,00 \\
\hline B2 & 1 & 25,00 \\
\hline Totais & 4 & 100,00 \\
\hline
\end{tabular}

Sobre a formação dos quatro alunos que cursam inglês, o Quadro 12 mostra que um aluno (25\%) tem o ensino médio completo, dois alunos $(50 \%)$ têm ensino superior incompleto, e o aluno restante (25\%) tem pós-graduação.

\begin{tabular}{|c|c|c|}
\hline Formação & Total & $\%$ \\
\hline SEM & 0 & 0,00 \\
\hline EMI & 0 & 0,00 \\
\hline EMC & 1 & 25,00 \\
\hline SI & 2 & 50,00 \\
\hline SC & 0 & 0,00 \\
\hline Pós & 1 & 25,00 \\
\hline Totais & 4 & 100,00 \\
\hline
\end{tabular}

Quadro 12 - Formação dos alunos cursando inglês

Em relação ao grupo de alunos formados em francês, o Quadro 13 mostra que todos os alunos (quatro - 100\%) estão na faixa etária dos 20 anos aos 30 anos.

\begin{tabular}{|c|c|c|}
\hline Idade (em anos) & Total & $\%$ \\
\hline $\mathbf{1 0}$ a 20 & 0 & 0,00 \\
\hline $\mathbf{2 0}$ a $\mathbf{3 0}$ & 4 & 100,00 \\
\hline Totais & 4 & 100,00 \\
\hline
\end{tabular}

Quadro 13 - Faixa etária dos alunos formados em francês 
No que diz respeito ao sexo desses alunos, é possível observar no Quadro 14 que um aluno (25\%) se identifica como homem. Já os $75 \%$ (três alunos) restantes se identificam como mulheres.

\begin{tabular}{|c|c|c|}
\hline Sexo & Total & \% \\
\hline $\mathbf{M}$ & 1 & 25,00 \\
\hline $\mathbf{F}$ & 3 & 75,00 \\
\hline Totais & 4 & 100,00 \\
\hline
\end{tabular}

\section{Quadro 14 - Sexo dos alunos formados em francês}

Usando aqui também o Quadro Comum Europeu de Referência para Línguas como parâmetro, conforme mostrado no Quadro 15, um aluno (25\%) se formou no nível B1 de língua francesa e os três alunos restantes (75\%) se formaram no nível B2 de língua francesa.

\begin{tabular}{|c|c|c|}
\hline Nível & Total & \% \\
\hline A1 & 0 & 0,00 \\
\hline A2 & 0 & 0,00 \\
\hline B1 & 1 & 25,00 \\
\hline B2 & 3 & 75,00 \\
\hline Totais & 4 & 100,00 \\
\hline
\end{tabular}

Quadro 15 - Nível dos alunos formados em francês

No tocante à formação acadêmica dos alunos formados em francês, todos os quatro alunos entrevistados apresentam diferentes formações.

Verifica-se no Quadro 16 que um aluno (25\%) tem o ensino médio completo; um aluno (25\%) tem o ensino superior incompleto; um aluno (25\%) tem o ensino superior completo; e o aluno restante (25\%) tem pós-graduação.

\begin{tabular}{|c|c|c|}
\hline Formação & Total & $\%$ \\
\hline SEM & 0 & 0,00 \\
\hline EMI & 0 & 0,00 \\
\hline EMC & 1 & 25,00 \\
\hline SI & 1 & 25,00 \\
\hline SC & 1 & 25,00 \\
\hline PÓS & 1 & 25,00 \\
\hline Totais & 4 & 100,00 \\
\hline
\end{tabular}

Quadro 16 - Formação dos alunos formados em francês 
No Quadro 17, analisando o último grupo, é possível constatar que todos os alunos formados em língua inglesa (quatro alunos) têm entre 20 anos e 30 anos de idade.

\begin{tabular}{|c|c|c|}
\hline Idade (em anos) & Total & $\mathbf{\%}$ \\
\hline $\mathbf{1 0}$ a $\mathbf{2 0}$ & 0 & 0,00 \\
\hline $\mathbf{2 0}$ a $\mathbf{3 0}$ & 4 & 100,00 \\
\hline Totais & 4 & 100,00 \\
\hline
\end{tabular}

Quadro 17 - Faixa etária dos alunos formados em inglês

Além disso, verifica-se no Quadro 18 que, dentre os entrevistados, três (75\%) se identificam como homens e apenas um se identifica como mulher $(25 \%)$.

\begin{tabular}{|c|c|c|}
\hline Sexo & Total & $\%$ \\
\hline $\mathbf{M}$ & 3 & 75,00 \\
\hline $\mathbf{F}$ & 1 & 25,00 \\
\hline Totais & 4 & 100,00 \\
\hline
\end{tabular}

Quadro 18 - Sexo dos alunos formados em inglês

Em relação ao nível de inglês dos quatro alunos entrevistados, é constatado no Quadro 19 que todos os participantes (quatro alunos) são formados no nível B2, conforme o padrão de referência do QCER.

\begin{tabular}{|c|c|c|}
\hline Nível & Total & $\%$ \\
\hline A1 & 0 & 0,00 \\
\hline A2 & 0 & 0,00 \\
\hline B1 & 0 & 0,00 \\
\hline B2 & 4 & 100,00 \\
\hline Totais & 4 & 100,00 \\
\hline
\end{tabular}

Quadro 19 - Nível dos alunos formados em inglês

Por fim, no que diz respeito à formação acadêmica dos entrevistados formados em inglês, conforme mostrado no Quadro 20, 25\% (um aluno) do total têm o ensino médio completo e $75 \%$ (três alunos) do total têm o ensino superior incompleto. 


\begin{tabular}{|c|c|c|}
\hline Formação & Total & $\%$ \\
\hline SEM & 0 & 0,00 \\
\hline EMI & 0 & 0,00 \\
\hline EMC & 1 & 25,00 \\
\hline SI & 3 & 75,00 \\
\hline SC & 0 & 0,00 \\
\hline PÓS & 0 & 0,00 \\
\hline Totais & 4 & 100,00 \\
\hline
\end{tabular} \\ Quadro 20 - Formação dos alunos formados em inglês}

Ademais, a partir dos quadros analisados neste trabalho, pode-se observar no Quadro 21 que, dentre os 16 alunos participantes (100\%), quatro alunos têm o ensino médio completo (25\%). A maior parte, ou seja, dez alunos (62,5\%) têm o ensino superior incompleto; um aluno $(6,25 \%)$ tem o ensino superior completo; e o aluno restante $(6,25 \%)$ tem pós-graduação.

\begin{tabular}{|c|c|c|}
\hline Formação & Total & $\%$ \\
\hline SEM & 0 & 0,00 \\
\hline EMI & 0 & 0,00 \\
\hline EMC & 4 & 25,00 \\
\hline SI & 10 & 62,50 \\
\hline SC & 1 & 6,25 \\
\hline PÓS & 1 & 6,25 \\
\hline Totais & 16 & 100,00 \\
\hline
\end{tabular}

Quadro 21 - Formação dos alunos participantes

Para posterior identificação dos professores e alunos que participaram das entrevistas, conforme o Quadro 22, uma lista de siglas foi criada para os 20 participantes a fim de preservar a identidade de todos. Além disso, o sexo de cada professor e aluno também é identificado ao lado de suas respectivas siglas, já que, como mencionado anteriormente nesta seção, todos serão citados no corpo do texto com o gênero masculino. 


\begin{tabular}{|c|c|c|}
\hline Siglas & Descrição das siglas & Sexo \\
\hline PF1 & PROFESSOR DE FRANCÊS 1 & M \\
\hline PF2 & PROFESSOR DE FRANCÊS 2 & F \\
\hline PI1 & PROFESSOR DE INGLÊS 1 & M \\
\hline PI2 & PROFESSOR DE INGLÊS 2 & F \\
\hline CF1 & CURSANDO FRANCÊS 1 & M \\
\hline CF2 & CURSANDO FRANCÊS 2 & F \\
\hline CF3 & CURSANDO FRANCÊS 3 & F \\
\hline CF4 & CURSANDO FRANCÊS 4 & F \\
\hline Cl1 & CURSANDO INGLÊS 1 & M \\
\hline Cl2 & CURSANDO INGLÊS 2 & F \\
\hline Cl3 & CURSANDO INGLÊS 3 & F \\
\hline Cl4 & CURSANDO INGLÊS 4 & F \\
\hline FF1 & FORMADO EM FRANCÊS 1 & F \\
\hline FF2 & FORMADO EM FRANCÊS 2 & F \\
\hline FF3 & FORMADO EM FRANCÊS 3 & M \\
\hline FF4 & FORMADO EM FRANCÊS 4 & F \\
\hline FI1 & FORMADO EM INGLÊS 1 & M \\
\hline FI2 & FORMADO EM INGLÊS 2 & M \\
\hline Fl3 & FORMADO EM INGLÊS 3 & M \\
\hline Fl4 & FORMADO EM INGLÊS 4 & F \\
\hline Q
\end{tabular}

Quadro 22 - Siglas de identificação dos participantes

Na próxima Seção (5.2), serão analisadas as perguntas dos questionários aplicados aos professores e alunos de línguas inglesa e francesa que participaram desta pesquisa.

\subsection{Questionários}

Este trabalho buscou analisar as possíveis influências da ansiedade vivenciada em sala de aula.

Para isso, foi realizada uma pesquisa de campo com quatro professores de uma mesma escola de idiomas privada e 16 alunos de escolas de idiomas diferentes, privadas e públicas, conforme mencionado na Seção anterior (5.1).

Assim, foram entregues questionários com o intuito de coletar informações acerca da ansiedade durante o aprendizado de língua estrangeira (LE) e analisar os fatores que influenciam o ensino-aprendizagem de LE.

A metodologia utilizada foi a pesquisa qualiquantitativa, obtendo, dessa forma, tanto amostras numéricas quanto opiniões e atitudes em relação ao tema abordado. 


\section{- Professores}

Questionários iguais foram entregues por e-mail aos professores, sendo dois professores de inglês - um homem e uma mulher - e os outros dois, professores de francês - também um homem e uma mulher.

A faixa etária desses professores está entre 20 anos e 50 anos e cada um deles tem uma formação acadêmica diferente.

Neste trabalho, a fim de preservar a identidade dos entrevistados, os professores serão identificados por meio de siglas, conforme apresentadas na Seção 5.1.

Ao todo, foram feitas seis perguntas iguais em cada questionário. O modelo de questionário se encontra no Apêndice deste trabalho.

Pergunta 1 - Em qual/quais dessa(s) habilidade(s) você acha que seus alunos se sentem mais vulneráveis: leitura, escrita, fala ou compreensão oral? Por quê?

O intuito desta pergunta foi verificar a opinião dos professores em relação a qual habilidade desenvolvida em sala de aula seus alunos se sentiam mais vulneráveis.

A vulnerabilidade perante o desenvolvimento dessas habilidades pode ser observada em sala de aula durante diferentes tipos de conteúdo e/ou atividades.

Com isso, será possível verificar, através da maior ocorrência de comportamento, como e por que os alunos se sentem mais ou menos ansiosos em aulas de língua estrangeira.

Pergunta 2 - Os alunos se mostram mais receptivos com quais atividades aplicadas dentro de sala de aula? Como? Por quê?

O propósito desta pergunta foi verificar, segundo a visão dos professores, com quais atividades os alunos se mostravam mais receptivos, assim despertandoIhes o interesse e a motivação.

Além disso, foi investigado o porquê, de acordo com os professores, de essas atividades serem as favoritas de seus alunos, na grande maioria. 
Pergunta 3 - Para você, qual é a importância da afetividade professor-aluno na aprendizagem de língua estrangeira?

Com esta pergunta, buscou-se verificar se os professores estavam cientes da questão da afetividade professor-aluno, se eles julgavam esse fator importante e como isso pode contribuir de forma positiva para a aprendizagem.

Pergunta 4 - Você acha que os alunos que já falam outros idiomas estrangeiros se sentem mais confortáveis ao aprender um novo idioma? Por quê?

O intuito desta pergunta foi observar se os professores acham que os alunos que já falam um idioma estrangeiro têm mais ou menos facilidade para aprender um novo idioma, assim fazendo com que eles se sintam mais motivados ou não em relação ao processo de aprender uma língua estrangeira.

Pergunta 5 - Você tem alunos ansiosos? Como você os identifica? Você utiliza uma abordagem diferente com esses alunos?

Partindo do princípio de que os professores já estavam familiarizados com o termo e conceito de ansiedade, especialmente a ansiedade em sala de aula, o objetivo desta pergunta foi verificar se os professores sabem identificar esses alunos facilmente e se eles fazem uso de alguma metodologia diferente com esses alunos, apesar de não ter sido investigado mais a fundo se esses professores têm algum tipo de especialização no assunto.

Pergunta 6 - Você fala outros idiomas? Quais? Você dá aula de outros idiomas? Quais?

Com esta pergunta, buscou-se analisar se falar/lecionar outro idioma pode ter alguma influência positiva na forma com que os professores lecionam ou lidam com a ansiedade de LE.

\section{- Alunos}

Apesar de alunos de línguas francesa e inglesa terem participado desta pesquisa, questionários iguais foram aplicados a ambos os grupos. A única 
diferenciação foi a referência ao idioma; porém, nesta seção, por questões de simplicidade, os idiomas serão mencionados juntos nas perguntas. Por isso, no corpo do texto haverá menção às duas línguas entre barras (inglês/francês ou língua inglesa/francesa); e, como os questionários foram aplicados a alunos cursando os idiomas e a alunos já formados, foram utilizados dois tempos verbais (presente do indicativo e pretérito imperfeito), também mencionados entre barras (acha/achava). A única diferença encontra-se na Pergunta 11 que, apesar de tratar do mesmo conteúdo, foi redigida de forma diferente para os grupos de alunos cursando e aqueles já formados.

Os questionários foram enviados por e-mail a 16 alunos de diferentes escolas de idiomas, tanto públicas quando privadas. Oito alunos são de língua inglesa, sendo esse grupo subdivido em quatro alunos formados e quatro alunos cursando inglês; e os oito alunos restantes são de língua francesa, também subdivididos em quatro alunos formados e quatro alunos cursando francês.

Esses alunos (homens e mulheres) estão na faixa etária de 10 anos a 30 anos e têm diferentes formações acadêmicas.

De modo que todos tivessem suas identidades preservadas, os alunos também receberam siglas para que possam ser identificados durante este trabalho. O significado dessas siglas se encontra na Seção 5.1 .

Cada questionário contém 11 perguntas e todos se encontram no Apêndice do presente trabalho.

Pergunta 1 - O que você acha/achava das aulas de inglês/francês?

O objetivo desta pergunta era analisar a opinião dos alunos em relação às aulas de inglês/francês.

Pergunta 2 - Por que escolheu estudar inglês/francês?

O propósito desta pergunta foi analisar quais motivações levaram os alunos a escolher estudar inglês/francês. 
Pergunta 3 - O que você acha/achava do seu professor de inglês/francês?

Esta pergunta tinha como objeto investigar a opinião dos alunos em relação aos seus professores, buscando palavras que exprimissem valor afetivo ou de julgamento. Esta pergunta também serviu de base para a próxima pergunta do questionário.

Pergunta 4 - Para você, qual é/era a importância da relação professor-aluno para sua aprendizagem? Por quê?

O propósito desta pergunta foi verificar se os alunos julgavam importante ter uma boa relação com os seus professores, assim criando um ambiente de afetividade entre professor e aluno.

Pergunta 5 - Com qual/quais dessas habilidades você se sente/sentia mais confortável: leitura, escrita, fala ou compreensão oral? Por quê?

Com esta pergunta, o intuito era investigar qual habilidade trazia mais conforto para os alunos dentro da sala de aula, sendo assim um possível fator que os motivasse.

Pergunta 6 - Com qual/quais dessas habilidades você se sente/sentia mais desconfortável: leitura, escrita, fala, ou compreensão oral? Por quê?

Diferentemente da pergunta anterior, esta pergunta tinha como propósito verificar qual habilidade trazia mais desconforto para os alunos e, assim, possivelmente, despertar um sentimento de ansiedade neles.

Pergunta 7 - Como você se sente/sentia quando o professor faz/fazia perguntas em inglês/francês diretamente a você?

O intuito desta pergunta foi verificar qual sentimento era despertado nos alunos quando eles recebiam uma pergunta no idioma estrangeiro que estudavam. 
Pergunta 8 - Qual/Quais sentimentos a sala de aula traz/trazia a você?

Esta pergunta teve como objetivo analisar a opinião dos alunos em relação a qual/quais sensação(ões) a sala de aula despertava neles. Foi possível que eles escolhessem mais de uma opção dentre as que lhes foram apresentadas: Segurança; Motivação; Ansiedade; Medo; e Outro(s).

Pergunta 9 - Quais atividades aplicadas na aula de língua inglesa/francesa você mais gosta/gostava?

O propósito desta pergunta foi verificar com quais atividades os alunos eram mais receptivos, dessa forma despertando a motivação deles.

Pergunta 10 - Você fala outros idiomas? Se sim, quais? Você acredita que fala outro idioma facilitou seu aprendizado de língua inglesa/francesa? Por quê?

O intuito desta pergunta era investigar se os alunos já falavam outro idioma estrangeiro e qual era a opinião deles em relação à menor ou maior facilidade em repetir este processo.

Pergunta 11 (cursando) - Você já estudou inglês/francês antes ou é a primeira vez? Se já, qual foi o motivo da desistência anteriormente? / Pergunta 11 (formados) - Você desistiu do curso em algum momento? Se sim, qual foi o motivo?

Estas perguntas tinham como objetivo investigar a ocorrência de desistência na aprendizagem de LE e suas motivações.

\subsubsection{Professores}

Esta seção tem como objetivo analisar as respostas às perguntas dos questionários aplicados aos professores de língua inglesa e francesa de uma escola de idiomas privada. A análise dos dados pessoais destes professores encontra-se na Seção 5.1 do presente trabalho. 
Apesar de haver dois grupos de professores nesta pesquisa (professores de francês e inglês), por questões de simplicidade, as respostas de ambos os grupos serão analisadas juntas.

Nesta seção, haverá algumas siglas, sendo elas as siglas presentes na Pergunta 1, referente às habilidades linguísticas ( $\mathrm{L}$ - Leitura; E - Escrita; F - Fala; CO - Compreensão Oral).

Além disso, no decorrer do texto, reaparecerão as siglas já mencionadas na Seção 5.1 do presente trabalho, que fazem referência aos professores (PF1 professor de francês 1; PF2 - professor de francês 2; PI1 - professor de inglês 1; PI2 - professor de inglês 2).

Pergunta 1 - Em qual dessas habilidades você acha que seus alunos se sentem mais vulneráveis: leitura, escrita, fala ou compreensão oral? Por quê?

\begin{tabular}{|c|c|}
\hline Habilidades & Totais \\
\hline L & 0 \\
\hline E & 1 \\
\hline F & 3 \\
\hline CO & 1 \\
\hline
\end{tabular}

Quadro 23 - Respostas dos professores - habilidades - Pergunta 1

No Quadro 23, é possível perceber que há uma menção à escrita, três menções à fala e uma menção à compreensão oral como sendo as habilidades que mais deixam os alunos vulneráveis. No Quadro 24, registra-se o desenvolvimento dessas escolhas.

\begin{tabular}{|c|l|}
\hline Professores & \multicolumn{1}{c|}{ Respostas } \\
\hline PF1 & (F) Insegurança, vulnerabilidade. Criar frases próprias e rapidamente. \\
\hline PF2 & (F e CO) Agir de imediato. Pressão e tensão extrema. \\
\hline PI1 & (F) Vergonha de falar errado. Quantidade de alunos. Comparação. \\
\hline PI2 & (E) Produção autoral. \\
\hline
\end{tabular}

Quadro 24 - Respostas dos professores - Pergunta 1

Com os Quadros 23 e 24, pode-se perceber que a fala é mencionada como sendo uma das habilidades que mais traz vulnerabilidade aos alunos (três menções). Entre os motivos estão insegurança, vulnerabilidade, vergonha, comparação com os demais colegas, pressão e a demanda de criar frases sozinhos e falar de uma maneira mais ágil. 
Todas essas características são causadoras de ansiedade, pois despertam nos alunos o sentimento de alerta e expectativa pelo que pode acontecer e, como mencionado no Capítulo 4 do presente trabalho, Pinto (2000) esclarece que existe o medo de ser avaliado negativamente e de parecer ridículo por parte das pessoas que vivenciam a ansiedade.

Além disso, Goffman (1967) explica o medo de ser avaliado negativamente como sendo a exposição pública do self, ou seja, a imagem que o indivíduo tenta preservar durante as interações. Portanto, ainda segundo o autor, fica evidente que os alunos têm sua face ameaçada ao se exporem verbalmente, assim gerando sentimentos de vergonha, insegurança, vulnerabilidade e despertando, consequentemente, a ansiedade.

Ademais, a professora PF2 ainda aponta a compreensão oral como uma habilidade causadora de vulnerabilidade nos alunos, também por se sentirem pressionados e precisarem agir rapidamente.

Já a professora PI2 acredita que a habilidade que mais deixa os alunos vulneráveis é a escrita, pois demanda uma produção autoral por parte dos alunos.

Pergunta 2 - Os alunos se mostram mais receptivos com quais atividades aplicadas dentro de sala de aula? Como? Por quê?

\begin{tabular}{|c|l|}
\hline Professores & \multicolumn{1}{c|}{ Respostas } \\
\hline PF1 & $\begin{array}{l}\text { Atividade de compreensão oral e textual. Eles se sentem mais confortáveis, sem } \\
\text { responsabilidade de criação. }\end{array}$ \\
\hline PF2 & $\begin{array}{l}\text { Atividades individuais, de escrita ou leitura. Atividades que não tenham que se } \\
\text { expor. }\end{array}$ \\
\hline PI1 & $\begin{array}{l}\text { Músicas e situações cotidianas. Eles vivenciam esse tipo de situação em suas } \\
\text { vidas particulares. }\end{array}$ \\
\hline PI2 & Atividades lúdicas, como games. Fogem da estrutura formal. \\
\hline
\end{tabular}

Quadro 25 - Respostas dos professores - Pergunta 2

Em relação ao Quadro 25, é possível analisar que os professores apontaram diferentes atividades que chamam a atenção dos alunos. Os professores PF1 e PF2 apontaram a compreensão textual, pois os alunos não precisam se expor e não há responsabilidade de criação autoral.

A professora PF2 (Quadro 25) ainda aponta que os alunos preferem atividades individuais, reforçando ainda mais a questão da preservação de face proposta por Goffman (1967).

Os professores PI1 e PI2 (Quadro 25) apostam nas atividades mais dinâmicas como músicas, games e debates, pois elas fogem da estrutura formal e 
se aproximam do cotidiano dos alunos. Nesse quesito, esses professores se unem ao conceito da metodologia comunicativa de Hymes (1990), em que o professor cria situações efetivas e reais, encorajando o aluno a fazer o uso real da língua.

Pergunta 3 - Para você, qual é a importância da afetividade professor-aluno na aprendizagem de língua estrangeira?

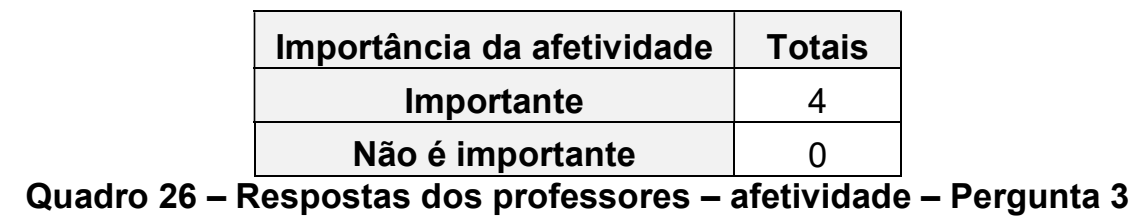

No Quadro 26, pode-se perceber que todos os professores (quatro professores) acham que a relação professor-aluno é importante.

\begin{tabular}{|c|l|}
\hline Professores & \multicolumn{1}{c|}{ Respostas } \\
\hline PF1 & $\begin{array}{l}\text { Muito importante. O professor pode servir de exemplo, despertando uma } \\
\text { motivação extra. }\end{array}$ \\
\hline PF2 & Faz toda a diferença. O aluno se sente mais seguro e confiante. \\
\hline PI1 & $\begin{array}{l}\text { De extrema importância. Precisamos de motivação. Somos exemplos e espelhos } \\
\text { para eles. }\end{array}$ \\
\hline PI2 & $\begin{array}{l}\text { Primordial. O professor precisa inspirar o aluno. Nem sempre é possível; existem } \\
\text { limites intransponíveis, às vezes familiares. }\end{array}$ \\
\hline
\end{tabular}

Quadro 27 - Respostas dos professores - Pergunta 3

No Quadro 27, pode ser verificado que os professores acreditam que eles são um exemplo e que eles precisam inspirar e motivar seus alunos. Dessa forma, os alunos se sentem mais seguros e confiantes.

Conforme citado na Seção 4.2 deste trabalho, os professores são responsáveis pela manutenção do estresse dos alunos dentro de sala de aula e um bom relacionamento entre eles faz com que a motivação e a participação dos alunos aumentem.

Em relação à resposta da professora $\mathrm{PI} 2$ (Quadro 27), é possível constatar que ela entra em consonância com o fato de que a educação parental, também apontada na Seção 4.1, pode ter grande influência no comportamento e na aprendizagem do aluno dentro de sala de aula.

Ademais, faz parte da documentação governamental que a afetividade seja levada em consideração no contexto ensino-aprendizagem. Ribeiro (2004, p. 406407 apud MORAIS, 2018, p. 31) aponta: 
Em síntese, a orientação oficial impõe ao formador o desenvolvimento de uma série de competências que ultrapassam a transmissão de um saber codificado numa disciplina e assegura um lugar ao desenvolvimento da dimensão afetiva nos professores.

Assim, conclui-se que o papel do professor vai muito além de ensinar e que todos os professores entrevistados nesta pesquisa estão cientes do papel afetivo que eles desempenham na aprendizagem de seus alunos.

Pergunta 4 - Você acha que os alunos que já falam outros idiomas estrangeiros se sentem mais confortáveis ao aprender um novo idioma? Por quê?

\begin{tabular}{|c|c|}
\hline Confortabilidade em aprender outra LE & Totais \\
\hline Sim & 4 \\
\hline Não & 0 \\
\hline
\end{tabular}

Quadro 28 - Respostas dos professores - alunos que falam outros idiomas - Pergunta 4

Todos os professores - quatro professores - acreditam que os alunos que já falam uma língua estrangeira têm maior facilidade para aprender uma segunda língua (Quadro 28).

\begin{tabular}{|c|c|}
\hline Professores & Respostas \\
\hline PF1 & $\begin{array}{l}\text { Já percorrido o caminho do aprendizado de uma língua, o aluno se sente mais } \\
\text { confiante, seguro e confortável. }\end{array}$ \\
\hline PF2 & $\begin{array}{l}\text { Eles já tiveram essa experiência e podem encará-la com mais segurança. O } \\
\text { conhecimento linguístico de uma língua auxilia na aquisição de outra. }\end{array}$ \\
\hline PI1 & Eles já sabem os altos e baixos, todas as diretrizes e estão mais adaptados. \\
\hline $\mathbf{P I 2}$ & $\begin{array}{l}\text { Eles já têm uma base de estudos, já ultrapassaram as barreiras existentes no } \\
\text { aprendizado de uma nova língua e cultura. }\end{array}$ \\
\hline
\end{tabular}

Quadro 29 - Respostas dos professores - Pergunta 4

Segundo os professores, como se vê no Quadro 29, a maior facilidade dos alunos que já falam uma outra língua estrangeira se deve ao fato de que eles já conhecem os processos acerca da aprendizagem de língua estrangeira, sentindo-se assim mais confiantes em repeti-los.

Como visto ao decorrer do Capítulo 4 deste trabalho e suas subseções, um aluno confiante e seguro influencia diretamente na manutenção da sua ansiedade linguística.

Além disso, a professora PF2 (Quadro 29) especifica que "o conhecimento linguístico de uma língua auxilia na aquisição de outra", entrando, assim, em consonância com a teoria gerativista de Chomsky (1988), em que todos os indivíduos cognitivamente capacitados possuem uma gramática universal (GU), ou 
seja, todas as línguas naturais têm princípios comuns. O que as diferencia seriam os parâmetros que criam as variações de uma para outra.

Assim, é possível concluir que, além de existir material teórico que aponte essa facilidade, existem fatores afetivos e emocionais que fazem com que os alunos se sintam mais confortáveis em explorar um ambiente previamente conhecido.

Pergunta 5 - Você tem alunos ansiosos? Como você os identifica? Você utiliza uma abordagem diferente com esses alunos?

\begin{tabular}{|c|c|}
\hline Alunos ansiosos & Totais \\
\hline Sim & 3 \\
\hline Não & 1 \\
\hline
\end{tabular}

Quadro 30 - Respostas dos professores - alunos ansiosos - Pergunta 5

No Quadro 30, três professores apontam que têm alunos ansiosos. Apenas um professor diz não ter identificado nenhum aluno ansioso.

\begin{tabular}{|c|l|}
\hline Professores & \multicolumn{1}{c|}{ Respostas } \\
\hline PF1 & Eles ficam mais tensos e nervosos. \\
\hline PF2 & $\begin{array}{l}\text { Geralmente eles se cobram demais, nunca estão satisfeitos e negam estarem } \\
\text { aprendendo. }\end{array}$ \\
\hline PI1 & $\begin{array}{l}\text { Eu os identifico pela velocidade que querem aprender o idioma, ou por acharem } \\
\text { que nunca estão evoluindo no aprendizado. }\end{array}$ \\
\hline PI2 & No momento, não. \\
\hline
\end{tabular}

Quadro 31 - Respostas dos professores - Pergunta 5

Partindo do pressuposto de que os professores entrevistados tenham conhecimento do conceito de ansiedade, três professores (PF1, PF2 e PI1) apontaram que os alunos ansiosos ficam tensos, negam estarem aprendendo/evoluindo e se cobram de forma exagerada (Quadro 31).

As respostas atenderam ao propósito da pergunta, pois, conforme já apontado na Seção 4.3, essas são características facilmente ligadas à questão das crenças e da ansiedade.

De acordo com Gardner (1988), os alunos que acreditam ter um mau desempenho e negam estar aprendendo tornam-se alunos ansiosos, muitas vezes fazendo com que alguns simplesmente desistam da aprendizagem de LE.

Isso acontece porque muitos alunos têm crenças irreais sobre a aprendizagem e sobre eles mesmos. Dessa forma, esses alunos se julgam inaptos a se comunicar em uma língua estrangeira, gerando falta de confiança e autoestima, duas grandes aliadas da ansiedade linguística. 
No Quadro 31, pode-se verificar que a maioria dos professores (três) sabe identificar seus alunos ansiosos e, é de extrema importância que eles saibam lidar com as crenças que esses alunos têm acerca do ensino-aprendizagem para que possam, posteriormente, ajudá-los na manutenção da ansiedade.

Pergunta 6 - Você fala outros idiomas? Quais? Você dá aula de outros idiomas? Quais?

\begin{tabular}{|c|c|}
\hline Falar/lecionar outros idiomas & Totais \\
\hline Sim & 1 \\
\hline Não & 3 \\
\hline
\end{tabular}

Quadro 32 - Respostas dos professores - idiomas - Pergunta 6

É verificado no Quadro 32 que apenas um professor fala e leciona outros idiomas. O restante dos entrevistados (três) não fala ou leciona outro idioma estrangeiro.

\begin{tabular}{|c|l|}
\hline Professores & \multicolumn{1}{c|}{ Respostas } \\
\hline PF1 & Um pouco de inglês. Leciono somente francês. \\
\hline PF2 & Falo e leciono italiano, inglês, espanhol, português e alemão. \\
\hline PI1 & Não. \\
\hline P12 & Um pouco de espanhol, mas não sou apta a dar aula. \\
\hline
\end{tabular}

Quadro 33 - Respostas dos professores - Pergunta 6

Pode-se perceber que a maioria dos professores (três) não fala ou leciona outro idioma, apenas o PF2 (Quadro 33). Com isso, fica evidente que falar ou lecionar outros ou vários idiomas não influencia na questão da afetividade/crença/ansiedade, visto que todos os professores atenderam ao propósito da pesquisa de modo geral ao mostrarem, em sua maioria, que identificam os alunos ansiosos e quais atividades os deixam mais desconfortáveis, assim tornando possível que eles (professores) utilizem diferentes abordagens a fim de ajudar esses alunos. Além disso, os professores se mostraram cientes com a questão da afetividade e como ela é importante para o desenvolvimento da aprendizagem de língua estrangeira de seus alunos.

\subsubsection{Alunos}

O intuito desta seção é analisar as respostas às perguntas dos questionários que foram enviados por e-mail aos alunos de língua inglesa e francesa de diferentes 
escolas de idiomas, tanto públicas quanto privadas. A análise de dados de todos os alunos que participaram desta pesquisa encontra-se na Seção 5.1 do presente trabalho.

As respostas dos alunos de francês e de inglês serão analisadas separadamente.

\subsubsection{Francês}

Nesta seção, serão analisadas as respostas às perguntas dos questionários aplicados aos alunos de francês.

Os alunos de francês estão divididos em alunos que ainda cursam o idioma (daqui para frente "cursando") e alunos que já se formaram (daqui para frente "formados"). No entanto, as perguntas foram as mesmas para ambos os grupos, apenas mudando seu tempo verbal (presente do indicativo e pretérito imperfeito), que aparece entre barras (acha/achava). A única pergunta que foi diferente entre os grupos cursando e formados foi a Pergunta 11, que trata do mesmo conteúdo, mas foi redigida que maneiras distintas. Mesmo assim, serão mencionadas juntas, assim como suas respostas.

Sendo assim, por questões de simplicidade, as respostas dos dois grupos serão analisadas de forma conjunta. Será possível diferenciar as respostas de ambos os grupos por meio dos títulos dos Quadros e das siglas que cada aluno recebeu (CF1 - cursando francês 1; CF2 - cursando francês 2; CF3 - cursando francês 3; CF4 - cursando francês 4; FF1 - formado em francês 1; FF2 - formado em francês 2; FF3 - formado em francês 3; FF4 - formado em francês 4). É importante ressaltar que os números que aparecem nas siglas não se referem ao nível de francês, mas sim ao número do aluno (CF1 é referente ao aluno 1 cursando francês, e assim por diante).

Também são utilizadas siglas que fazem referência às quatro habilidades linguísticas nas Perguntas 5 e 6, sendo elas L - Leitura; E - Escrita; F - Fala; e CO - Compreensão Oral. 
Pergunta 1 - O que você acha/achava das aulas de francês?

\begin{tabular}{|c|l|}
\hline Alunos & \multicolumn{1}{|c|}{ Respostas } \\
\hline CF1 & Incríveis. Consigo relaxar da rotina. \\
\hline CF2 & Boas, porém pobres em cultura cotidiana francesa. \\
\hline CF3 & $\begin{array}{l}\text { Gosto das aulas de francês por serem um momento de alívio e de me dedicar a } \\
\text { algo que me interesso e gosto. }\end{array}$ \\
\hline CF4 & Gosto bastante, me sinto estimulada a aprender. \\
\hline
\end{tabular}

Quadro 34 - Respostas dos alunos cursando francês - Pergunta 1

No Quadro 34, todos os alunos cursando francês (quatro alunos) dizem gostar das aulas de língua francesa. Contudo, a aluna CF2, apesar de achar as aulas boas, faz uma crítica à falta de inserção na cultura francesa durante as aulas.

\begin{tabular}{|c|l|}
\hline Alunos & \multicolumn{1}{c|}{ Respostas } \\
\hline FF1 & Amava. \\
\hline FF2 & Maravilhosas. \\
\hline FF3 & Muito didáticas, divertidas e produtivas. \\
\hline FF4 & Muito dinâmicas. \\
\hline \multicolumn{2}{|c|}{ Quadro 35 - Respostas dos alunos formados em francês - Pergunta 1 } \\
\hline
\end{tabular}

Como é possível observar (Quadro 35), todos os alunos formados em francês (quatro alunos) se mostraram bastante satisfeitos com as aulas de francês.

Dessa forma, ambos os grupos de alunos (cursando e formados) atribuíram, com exceção da aluna CF2, palavras de valor positivo em relação às aulas que eles têm/tinham (Quadros 34 e 35).

Conforme aponta Allwright (2006), a sala de aula deve constituir um ambiente onde haja qualidade de vida para seus participantes, ou seja, professores e alunos. Segundo o autor, como já mencionado na Seção 4.1 deste trabalho, essa qualidade serve para "[...] encorajar as pessoas a serem eternos aprendizes". A aluna CF4 traduz essa afirmação ao dizer que se sente "estimulada a aprender" (Quadro 34).

Portanto, as palavras de teor positivo utilizadas pelos alunos (Quadros $34 \mathrm{e}$ 35), "maravilhosas; produtivas; incríveis", reforçam essa ideia de ter um ambiente de qualidade, que traga conforto e segurança.

Em relação à aluna CF2 (Quadro 34), especificamente, é possível perceber que sua motivação integrada pode ter sido frustrada, já que, conforme Gardner e Lambert (1959), o interesse pela cultura e pela tradição surgem naturalmente nos aprendizes que têm esse tipo de motivação.

Entretanto, de forma geral, as aulas de ambos os grupos foram elogiadas. 
Pergunta 2 - Por que escolheu estudar francês?

\begin{tabular}{|c|c|}
\hline Motivação & Totais \\
\hline Profissional & 1 \\
\hline Cultural & 2 \\
\hline Hobby & 2 \\
\hline
\end{tabular}

Quadro 36 - Respostas dos alunos cursando francês - motivação - Pergunta 2

No Quadro 36, pode-se ver que houve uma menção à motivação profissional, duas menções à motivação cultural e outras duas menções à motivação por hobby.

\begin{tabular}{|c|c|}
\hline Motivação & Totais \\
\hline Profissional & 0 \\
\hline Cultural & 2 \\
\hline Hobby & 3 \\
\hline
\end{tabular}

Quadro 37 - Respostas dos alunos formados em francês - motivação - Pergunta 2

No Quadro 37, não há nenhuma menção à motivação profissional. É perceptível que os alunos escolheram estudar francês por motivações culturais (duas menções) e por motivações por hobby (três menções).

Com isso, conclui-se que, nos dois grupos de alunos (cursando e formados), há maior incidência de motivação por hobby contendo, no todo, cinco menções, e cultural contendo, no todo, quatro menções. A motivação profissional teve apenas uma menção, no todo.

\begin{tabular}{|c|l|}
\hline Alunos & \multicolumn{1}{|c|}{ Respostas } \\
\hline CF1 & $\begin{array}{l}\text { Me interessei depois de conhecer uma parte da família que mora na França. } \\
\text { Além disso, tinha vontade de fazer intercâmbio na França. }\end{array}$ \\
\hline CF2 & $\begin{array}{l}\text { Tenho como objetivo aprender línguas novas sempre que possível. O francês é } \\
\text { uma língua que me atrai bastante. }\end{array}$ \\
\hline CF3 & $\begin{array}{l}\text { Por achar uma língua atraente, ter facilidade em aprender idiomas e querer } \\
\text { conhecer e morar em alguns países que falam a língua. }\end{array}$ \\
\hline CF4 & $\begin{array}{l}\text { Gosto bastante, me sinto estimulada a aprender. Tenho como hobby aprender } \\
\text { línguas. }\end{array}$ \\
\hline
\end{tabular}

Quadro 38 - Respostas dos alunos cursando francês - Pergunta 2 


\begin{tabular}{|c|l|}
\hline Alunos & \multicolumn{1}{|c|}{ Respostas } \\
\hline FF1 & $\begin{array}{l}\text { Sempre achei o francês muito bonito, mas foi estudando que me apaixonei pelo } \\
\text { idioma; com a possibilidade de me comunicar com o mundo. }\end{array}$ \\
\hline FF2 & $\begin{array}{l}\text { Sempre gostei de estudar idiomas. Me encanta aprender línguas, conhecer tudo } \\
\text { o que o estudo do idioma traz junto da cultura. O som do falar em francês me } \\
\text { encantava. }\end{array}$ \\
\hline FF3 & $\begin{array}{l}\text { Sempre gostei de estudar idiomas. O francês a meu ver sempre foi o mais } \\
\text { bonito de todos. }\end{array}$ \\
\hline FF4 & $\begin{array}{l}\text { Por acaso. Nunca tinha tido contato antes. Infelizmente, o francês não é tão } \\
\text { popular quanto o inglês. }\end{array}$ \\
\hline
\end{tabular}

Quadro 39 - Respostas dos alunos formados em francês - Pergunta 2

Com os Quadros 38 e 39, é possível examinar as respostas dos grupos cursando e formados.

Como visto nos Quadros anteriores (36 e 37), houve maior incidência em relação à motivação por hobby (cinco menções) e à motivação cultural (quatro menções).

Em relação ao desejo natural por aprender uma língua (hobby), Costa e Souza (2003) apontam que este desejo surgiria a partir de uma motivação intrínseca, ou seja, muitas pessoas escolhem estudar outra língua apenas pelo prazer de aprender e/ou pelo desejo de se comunicar com outras pessoas.

Contudo, em relação à motivação cultural, Gardner e Lambert (1959) a nomearam de motivação integrada, em que o aprendiz se interessa naturalmente pela cultura e pelas tradições de um determinado povo.

Dessa forma, ainda segundo Gardner e Lambert (1959), os alunos motivados intrinsicamente e/ou culturalmente tendem a ter maior sucesso em relação à aprendizagem pelo fato de ser um processo mais natural do que para aqueles que aprendem por uma motivação profissional.

\section{Pergunta 3 - O que você acha/achava do seu professor de francês?}

\begin{tabular}{|c|l|}
\hline Alunos & \multicolumn{1}{|c|}{ Resposta } \\
\hline CF1 & $\begin{array}{l}\text { Gosto da minha professora. Ela envolve didática, comprometimento e carinho } \\
\text { com os alunos. }\end{array}$ \\
\hline CF2 & Foram satisfatórios. Presentes, dedicados e dispostos a ajudar sempre. \\
\hline CF3 & $\begin{array}{l}\text { Extremamente profissional e empenhada em elaborar aulas com métodos } \\
\text { diferentes e didáticos. }\end{array}$ \\
\hline CF4 & $\begin{array}{l}\text { O primeiro apresentou o conteúdo muito bem, mas faltou interdisciplinaridade. A } \\
\text { segunda conseguiu juntar os dois. }\end{array}$ \\
\hline
\end{tabular}

Quadro 40 - Respostas dos alunos cursando francês - Pergunta 3

Verifica-se (Quadro 40) que todos os alunos cursando francês (quatro alunos) mostraram gostar do professor, incluindo elogios como didático, comprometido e 
carinhoso. Apenas a aluna CF4 fez uma crítica ao dizer que seu primeiro professor não mostrou interdisciplinaridade.

\begin{tabular}{|c|l|}
\hline Alunos & \multicolumn{1}{|c|}{ Respostas } \\
\hline FF1 & $\begin{array}{l}\text { Maravilhosos. Eles levavam jogos, músicas, criavam eventos típicos e tinham a } \\
\text { sensibilidade de ver quem não estava acompanhado, trazendo atividades } \\
\text { extras. }\end{array}$ \\
\hline FF2 & $\begin{array}{l}\text { Extremamente inteligentes e capazes de ensinar. Admiro as formas diferentes } \\
\text { que cada um utilizou para a minha aprendizagem. }\end{array}$ \\
\hline FF3 & $\begin{array}{l}\text { Tive as melhores professoras. Eram compreensivas, amigas e calmas. } \\
\text { Excelentes. }\end{array}$ \\
\hline FF4 & $\begin{array}{l}\text { Atenciosos e capacitados. As aulas não se tratavam apenas do ensino do } \\
\text { idioma, havia também uma imersão cultural. }\end{array}$ \\
\hline
\end{tabular}

Quadro 41 - Respostas dos alunos formados em francês - Pergunta 3

No Quadro 41, pode-se constatar que todos os alunos (100\% - quatro alunos) mostraram ter gostado de seus professores, incluindo elogios como sensíveis, amigos, compreensivos.

Conforme os estudos de Bekleyen (2004), os alunos de língua estrangeira sentem-se mais confortáveis com professores que se mostram gentis e dinâmicos. Os alunos acreditam que o professor deve oferecer uma atmosfera de conforto, e não uma atmosfera autoritária, de hierarquia. Com isso, os alunos depositam sua confiança e suas crenças nos professores, esperando um ambiente confortável e seguro para sua aprendizagem.

Nos Quadros 40 e 41 é possível perceber que os professores dos alunos cursando francês e formados em francês conseguiram cumprir o papel de professores facilitadores/mediadores.

Pergunta 4 - Para você, qual é/era a importância da relação professor-aluno para sua aprendizagem? Por quê?

\begin{tabular}{|c|c|}
\hline Importância da afetividade & Totais \\
\hline Importante & 4 \\
\hline Não é importante & 0 \\
\hline
\end{tabular}

Quadro 42 - Respostas dos alunos cursando francês - afetividade - Pergunta 4

No Quadro 42, é possível analisar que todos os quatro alunos entrevistados cursando francês (100\%) acreditam que a relação professor-aluno é importante. 


\begin{tabular}{|c|c|}
\hline Importância da afetividade & Totais \\
\hline Importante & 4 \\
\hline Não é importante & 0 \\
\hline
\end{tabular}

\section{Quadro 43 - Respostas dos alunos formados em francês - afetividade - Pergunta 4}

Quanto aos alunos formados em francês (Quadro 43), 100\% dos entrevistados (quatro alunos) mencionaram que a relação professor-aluno é importante.

Com isso, fica evidente que ambos os grupos de alunos de francês (cursando e formados) acreditam na importância da afetividade entre eles e seus professores para a aprendizagem do idioma em questão (Quadros 42 e 43).

\begin{tabular}{|c|l|}
\hline Alunos & \multicolumn{1}{|c|}{ Respostas } \\
\hline CF1 & $\begin{array}{l}\text { Extremamente importante. Uma boa relação motiva a estudar, a ir às aulas e } \\
\text { dar o seu melhor. }\end{array}$ \\
\hline CF2 & $\begin{array}{l}\text { Essa relação é importante para dar ao aluno uma maior abertura de se } \\
\text { expressar e tirar dúvidas. Às vezes o aluno omite dúvidas por não se sentir } \\
\text { confortável com o professor. }\end{array}$ \\
\hline CF3 & $\begin{array}{l}\text { Uma boa relação pode tornar o aprendizado mais leve e motivar o aluno a } \\
\text { frequentar as aulas e se dedicar. }\end{array}$ \\
\hline CF4 & $\begin{array}{l}\text { Extremamente importante. Em uma relação de ensino, quanto mais próximo } \\
\text { estiver da fonte, mais você aprende. }\end{array}$ \\
\hline
\end{tabular}

Quadro 44 - Respostas dos alunos cursando francês - Pergunta 4

\begin{tabular}{|c|l|}
\hline Alunos & \multicolumn{1}{|c|}{ Respostas } \\
\hline FF1 & $\begin{array}{l}\text { Total importância. O relacionamento com o professor está ligado diretamente no } \\
\text { psicológico do estudante. O estudante pode passar a odiar uma matéria por } \\
\text { causa do professor. Se eu tenho um professor que me motiva, me sinto } \\
\text { motivada a aprender cada vez mais. Um bom profissional inspira os outros. }\end{array}$ \\
\hline FF2 & $\begin{array}{l}\text { O bom professor precisa fazer uma análise do aluno para entender qual método } \\
\text { é melhor para ele. Busco me comunicar com o professor para aprender o } \\
\text { conteúdo. Precisa haver identificação. Se essa relação vai bem, o aprendizado } \\
\text { também vai. Ter professores com quem me identifico, respeito e admiro me } \\
\text { estimula muito mais a pesquisar e evoluir. }\end{array}$ \\
\hline FF3 & $\begin{array}{l}\text { Sem dúvidas a didática e a compreensão. Me sentia confiante ao falar e não } \\
\text { tinha medo de errar. }\end{array}$ \\
\hline FF4 & $\begin{array}{l}\text { É muito importante que haja uma relação de parceria entre o aluno e professor. } \\
\text { Até mesmo para deixar os alunos tímidos mais à vontade, sem deixar que a } \\
\text { timidez atrapalhe. }\end{array}$ \\
\hline
\end{tabular}

Quadro 45 - Respostas dos alunos formados em francês - Pergunta 4

Nos Quadros 44 e 45 é possível analisar mais a fundo as respostas dos alunos em relação à afetividade. O termo "afetividade" não foi utilizado nas perguntas, a fim de não exercer uma possível influência nas respostas dos alunos.

Muitos alunos mencionaram a motivação como o maior fruto da relação professor-aluno. Em relação à influência do bom relacionamento em sala de aula, Ribeiro (2010, p. 404) esclarece: 
Fica evidente que os estudantes apreciam mais as disciplinas ministradas por professores com os quais se relacionam melhor, pois a conduta desses profissionais influencia a motivação, a participação e a dedicação aos estudos.

A aluna FF1 (Quadro 45) expressa bem a passagem de Ribeiro (2010, p. 404), "[...] os estudantes apreciam mais as disciplinas ministradas por professores com os quais se relacionam melhor [...]", ao dizer em sua resposta que "o estudante pode passar a odiar uma matéria por causa do professor".

Dito isso, compreende-se que os alunos podem gostar de uma matéria e se sentirem motivados exclusivamente por causa do professor.

Entrando em consonância com o que foi dito por Ribeiro (2010) em relação à participação, a aluna CF2 (Quadro 44) diz que "às vezes, o aluno omite dúvidas por não se sentir confortável com o professor". Ou seja, a afetividade tem um papel muito importante na vida do aluno, contribuindo para que ele seja um participante ativo dentro de sala de aula.

Além desse bom relacionamento que motiva e inspira os alunos, os professores acabam sendo responsáveis pela diminuição da ansiedade dos alunos, como bem apontam os alunos FF3 ("me sentia confiante ao falar e não tinha medo de errar") e o aluno FF4 no Quadro 45 ("é muito importante que haja uma relação de parceria [...] para deixar os alunos tímidos mais à vontade, sem deixar que a timidez atrapalhe").

Como visto ao longo do Capítulo 4 do presente trabalho e suas subseções, o medo, a timidez e a falta de confiança são fatores que contribuem para a ansiedade linguística; portanto, a afetividade pode fazer com que esses comportamentos desapareçam ou diminuam significativamente.

Pergunta 5 - Com qual/quais dessas habilidades você se sente mais confortável: leitura, escrita, fala ou compreensão oral? Por quê?

\begin{tabular}{|c|c|}
\hline Habilidades & Totais \\
\hline L & 4 \\
\hline E & 2 \\
\hline F & 0 \\
\hline CO & 1 \\
\hline
\end{tabular}

Quadro 46 - Respostas dos alunos cursando francês - conforto com as habilidades Pergunta 5 
No Quadro 46, houve quatro menções à leitura, duas menções à escrita, nenhuma menção à fala e uma menção à compreensão oral como as habilidades com que os alunos cursando francês se sentem mais confortáveis.

\begin{tabular}{|c|c|}
\hline Habilidades & Totais \\
\hline L & 1 \\
\hline E & 1 \\
\hline F & 3 \\
\hline CO & 2 \\
\hline
\end{tabular}

Quadro 47 - Respostas dos alunos formados em francês - conforto com as habilidades Pergunta 5

Houve uma menção à leitura, uma menção à escrita, três menções à fala e duas menções à compreensão oral como as habilidades com que os alunos formados em francês mais se sentiam confortáveis (Quadro 47).

\begin{tabular}{|c|l|}
\hline Alunos & \multicolumn{1}{|c|}{ Respostas } \\
\hline CF1 & $\begin{array}{l}\text { Leitura. Consigo aprender novas palavras da forma correta e desenvolvo uma } \\
\text { maior proximidade com o idioma. }\end{array}$ \\
\hline CF2 & Leitura e compreensão oral. Tenho mais facilidade. \\
\hline CF3 & $\begin{array}{l}\text { Leitura e escrita. Posso fazer na velocidade que me sinto mais confortável, } \\
\text { parar pra pensar, consultar um livro e me dedicar. }\end{array}$ \\
\hline CF4 & $\begin{array}{l}\text { Leitura e escrita. Conhecendo outras línguas românicas, a compreensão é mais } \\
\text { fácil. }\end{array}$ \\
\hline
\end{tabular}

Quadro 48 - Respostas dos alunos cursando francês - Pergunta 5

Pode-se perceber (Quadro 48) que todos os alunos cursando francês (quatro) mencionam a leitura como a habilidade que mais traz a sensação de conforto em sala de aula.

Conforme visto na Seção 5.2.1 do presente trabalho, os professores de francês (PF1 e PF2 - Quadro 25) que participaram desta pesquisa, apesar de não serem os professores dos alunos entrevistados, apontaram que os alunos, geralmente, são mais receptivos com atividades que envolvem compreensão textual (leitura), pois se sentem menos expostos e não possuem a responsabilidade de criação.

O foco na leitura e na aprendizagem de vocabulário remete ao ensino tradicional de língua estrangeira, porém, como aponta Leffa (2016), o foco na leitura faz com o que os alunos deixem a produção oral de lado, que é uma das habilidades mais importantes para que a comunicação seja estabelecida. 


\begin{tabular}{|c|l|}
\hline Alunos & \multicolumn{1}{|c|}{ Respostas } \\
\hline FF1 & Fala, leitura e compreensão oral. \\
\hline FF2 & $\begin{array}{l}\text { Fala. Falo muito. Gosto de me comunicar e o que busco com os idiomas é a } \\
\text { comunicação. Embora eu ame escrever, sou muito exigente com minhas } \\
\text { escritas e me sinto mais confortável com a fala. }\end{array}$ \\
\hline FF3 & $\begin{array}{l}\text { Fala e compreensão oral, visto que tenho convívio com nativos. Falar e ouvir } \\
\text { sempre foram fáceis para mim. }\end{array}$ \\
\hline FF4 & $\begin{array}{l}\text { Me sentia mais confortável com a escrita. É um momento particular, perfeito } \\
\text { para pessoas tímidas como eu. }\end{array}$ \\
\hline
\end{tabular}

Quadro 49 - Respostas dos alunos formados em francês - Pergunta 5

Em relação aos alunos formados em francês, pode-se perceber uma discrepância no tocante às respostas dos alunos cursando francês. Enquanto nenhum aluno cursando francês mencionou a fala, a maioria dos alunos formados em francês (Quadro 49 - FF1, FF2 e FF3) mencionaram a fala como a habilidade que mais traz conforto a eles.

Os alunos que gostam de falar não apresentam a apreensão comunicativa postulada por Horwitz, Horwitz e Cope (1986). Dessa forma, os alunos apresentam maior facilidade em se comunicar em língua estrangeira, visto que não têm medo de se expor.

No Quadro 49, apenas a aluna FF4 diz sentir-se mais confortável com a escrita, pois "é um momento particular, perfeito para pessoas tímidas". Ou seja, este aluno prefere preservar sua face, segundo a teoria de Goffman (1967), e não se expor devido à sua timidez - fator causador de ansiedade linguística.

Pergunta 6 - Com qual/quais das habilidades descritas acima você se sente/sentia mais desconfortável? Por quê?

\begin{tabular}{|c|c|}
\hline Habilidades & Totais \\
\hline L & 0 \\
\hline E & 1 \\
\hline F & 3 \\
\hline CO & 2 \\
\hline
\end{tabular}

Quadro 50 - Respostas dos alunos cursando francês - desconforto com as habilidades -

Pergunta 6

No Quadro 50, não há nenhuma menção à leitura, porém é verificado que há uma menção à escrita e três menções à fala como as habilidades que mais trazem desconforto aos alunos cursando francês. Também há duas menções à compreensão oral. 


\begin{tabular}{|c|c|}
\hline Habilidades & Totais \\
\hline L & 0 \\
\hline E & 3 \\
\hline F & 0 \\
\hline CO & 1 \\
\hline
\end{tabular}

Quadro 51 - Respostas dos alunos formados em francês - desconforto com as habilidades Pergunta 6

Quanto aos alunos formados em francês (Quadro 51), não há nenhuma menção à leitura, porém há três menções à escrita, nenhuma menção à fala, e uma menção à compreensão oral como as habilidades que mais trazem desconforto a eles.

\begin{tabular}{|c|l|}
\hline Alunos & \multicolumn{1}{|c|}{ Respostas } \\
\hline CF1 & $\begin{array}{l}\text { Fala. Sou tímido e falar em público em um idioma desconhecido é fora da minha } \\
\text { zona de conforto. }\end{array}$ \\
\hline CF2 & $\begin{array}{l}\text { Fala, por não conseguir pronunciar algumas palavras corretamente, e a escrita } \\
\text { por não conseguir lembrar como as palavras são escritas. }\end{array}$ \\
\hline CF3 & $\begin{array}{l}\text { Compreensão oral, pois muitas vezes foge da minha zona de conforto em } \\
\text { relação à velocidade. }\end{array}$ \\
\hline CF4 & $\begin{array}{l}\text { Fala e compreensão oral, por não saber pronunciar direito e ter dúvidas, além } \\
\text { de que a fala francesa é naturalmente muito rápida. }\end{array}$ \\
\hline
\end{tabular}

Quadro 52 - Respostas dos alunos cursando francês - Pergunta 6

No Quadro 52, podem-se verificar as respostas completas dos alunos cursando francês. Três alunos (CF1, CF2 e CF4) mencionaram a fala como uma habilidade que os deixa desconfortáveis. Portanto, a maioria dos alunos acredita que a fala é a causadora de maior desconforto. Entre os motivos estão a timidez e não conseguir pronunciar as palavras de maneira correta. Houve também duas menções à compreensão oral por parte dos alunos CF3 e CF4.

Assim, a fala e a compreensão foram as habilidades mais mencionadas pelos alunos cursando francês, o que ilustra bem o conceito de apreensão comunicativa proposto por Horwitz, Horwitz e Cope (1986). Segundo esses autores, os alunos têm medo de se comunicar em um idioma estrangeiro e também sentem medo de não entender o que o professor e/ou os colegas de classe estão falando. Com isso, os alunos sentem-se ameaçados, gerando, assim, uma possível ansiedade linguística. 


\begin{tabular}{|c|l|}
\hline Alunos & \multicolumn{1}{|c|}{ Respostas } \\
\hline FF1 & $\begin{array}{l}\text { Escrita. Tive dificuldades por causa dos acentos e da grafia de algumas } \\
\text { palavras. }\end{array}$ \\
\hline FF2 & $\begin{array}{l}\text { Não me sentia desconfortável com nenhuma. Mas se for para escolher uma, a } \\
\text { escrita. }\end{array}$ \\
\hline FF3 & Escrita. Devido à acentuação e alguns encontros vocálicos e consonantais. \\
\hline FF4 & Compreensão oral. Entender os áudios avançados era uma dificuldade. \\
\hline \multicolumn{2}{|c|}{ Quadro 53 - Respostas dos alunos formados em francês - Pergunta 6} \\
\end{tabular}

Assim como na análise das respostas da Pergunta 5 do questionário dos alunos de francês (cursando e formados - Quadros 48 e 49), as respostas da Pergunta 6 também apresentam uma grande diferença entre os dois grupos (cursando francês e formados em francês - Quadros 52 e 53).

No Quadro 53, são analisadas as respostas completas dos alunos formados em francês quanto ao desconforto em relação às habilidades. A maioria dos alunos (três alunos - FF1, FF2 E FF3) sente-se desconfortável com a escrita. Entre os motivos estão a acentuação e a grafia da língua francesa.

De acordo com Gomes e Pinheiro-Mariz (2011), isso se deve ao fato de que a escrita na língua estrangeira, assim como na língua materna, é a última habilidade a ser completamente desenvolvida. Enquanto a fala é um processo natural e inerente ao ser humano, a escrita é um processo mais artificial e deve ser aprendido.

Gomes e Pinheiro-Mariz (2011, p. 123) acrescentam:

[...] o nível de dificuldade na produção escrita deve ser proporcional ao conhecimento de língua francesa do aprendiz para que ele se sinta confortável e não pressionado diante de uma atividade escrita, uma vez que, mesmo em língua materna, é uma atividade que exige conhecimento do produtor (de textos).

Como visto no Capítulo 4 do presente trabalho e suas subseções, a pressão pode ser um fator desencadeador de ansiedade linguística. Dessa forma, conclui-se que os alunos formados em francês, ao pontuarem que essa foi a habilidade que causava maior desconforto neles, podem ter vivenciado a ansiedade durante seus estudos de língua francesa. 
Pergunta 7 - Como você se sente/sentia quando o professor faz/fazia perguntas em francês diretamente a você?

\begin{tabular}{|c|l|}
\hline Alunos & \multicolumn{1}{|c|}{ Respostas } \\
\hline CF1 & Desconfortável, mas é um incentivo pra me desenvolver mais. \\
\hline CF2 & Tranquila, mas nem sempre consigo formular as respostas sozinha. \\
\hline CF3 & $\begin{array}{l}\text { Sinto que é o momento de pôr em prática o que venho aprendendo e testar } \\
\text { minhas habilidades. }\end{array}$ \\
\hline CF4 & Nervoso, por conta da dúvida da pronúncia. \\
\hline & Quadro 54 - Respostas dos alunos cursando francês - Pergunta 7 \\
\hline
\end{tabular}

No Quadro 54, pode-se verificar que dois alunos (CF1 e CF4) usaram palavras que podem exprimir certo incômodo, como "desconfortável" e "nervoso" para descrever como se sentem em relação às perguntas feitas diretamente a eles em francês. As outras duas alunas que participaram do questionário (CF2 e CF3) disseram que se sentem tranquilas e que é o momento de praticar a língua.

\begin{tabular}{|c|l|}
\hline Alunos & \multicolumn{1}{c|}{ Respostas } \\
\hline FF1 & $\begin{array}{l}\text { Uma época, eu estava passando por problemas pessoais e teve uma aula em } \\
\text { que não respondi corretamente. Ela tentou me incentivar, mas eu travei. Fiquei } \\
\text { tão para baixo que fui embora. Depois disso, a professora começou a olhar a } \\
\text { resposta de cada um em privado. }\end{array}$ \\
\hline FF2 & $\begin{array}{l}\text { Satisfeita, adorava responder, falar, conversar e discutir temas em francês, } \\
\text { mesmo sabendo que cometeria algum erro. Nunca tive medo de falar errado. }\end{array}$ \\
\hline FF3 & Confortável e seguro para responder. \\
\hline FF4 & $\begin{array}{l}\text { Ficava bem nervosa. Com o tempo, a turma se tornou uma família e responder } \\
\text { às perguntas do professor se tornou algo natural. }\end{array}$ \\
\hline
\end{tabular}

Quadro 55 - Respostas dos alunos formados em francês - Pergunta 7

No tocante aos formados em francês (Quadro 55), constatou-se que duas alunas (FF1 e FF4) se sentiam desconfortáveis com as perguntas feitas diretamente a eles em francês. Por outro lado, os dois alunos restantes (FF2 e FF3) disseram se sentir satisfeitos e seguros para responder às perguntas.

Ao todo, nesta pergunta, quatro alunos (50\% dos alunos entrevistados entre cursando francês e formados em francês) sentem-se vulneráveis com as perguntas feitas pelos professores. Como visto no Capítulo 4 do presente trabalho, o nervosismo e o desconforto são traços da ansiedade.

Assim, quando esses alunos se sentem ansiosos especificamente com a prática de serem questionados, apresentam uma ansiedade-estado, segundo os estudos de Spielberger (1970), ou seja, uma ansiedade vivida numa situação específica, em que os indivíduos se sentem ameaçados.

A resposta da aluna FF1 (Quadro 55) é consoante com a resposta da professora PI2 (Seção 5.2.1 - Pergunta 3, Quadro 27), apesar de esta professora 
(PI2) não ser a professora da aluna FF1. Quando a aluna FF1 aponta que "estava passando por problemas pessoais" (Quadro 55) e por isso não conseguiu responder à pergunta, fazendo com que ela fosse embora da aula, a resposta da professora PI2 quanto à afetividade é reafirmada: "O professor precisa inspirar o aluno. Nem sempre é possível; existem limites intransponíveis, às vezes familiares” (Quadro 27).

$O$ fato de que problemas familiares podem afetar a aprendizagem de LE também é constatado por Sanchez Perez (1982), que já foi mencionado na Seção 3.1 deste trabalho, ao dizer que a motivação dos alunos em relação às aulas de língua estrangeira pode ser afetada por motivos pessoais e familiares.

Sendo assim, fica evidente que podem existir questões que vão além do controle do próprio aluno e, é claro, do professor também.

Pergunta 8 - Qual/Quais sentimento(s) a sala de aula traz/trazia a você?

\begin{tabular}{|c|c|c|c|c|c|}
\cline { 2 - 6 } \multicolumn{1}{c|}{} & \multicolumn{5}{c|}{ Sentimentos } \\
\hline Alunos & Segurança & Motivação & Ansiedade & Medo & Outro \\
\hline CF1 & $\mathrm{X}$ & $\mathrm{X}$ & & & \\
\hline CF2 & $\mathrm{X}$ & $\mathrm{X}$ & & & \\
\hline CF3 & & $\mathrm{X}$ & $\mathrm{X}$ & & \\
\hline CF4 & $\mathrm{X}$ & $\mathrm{X}$ & & & $\mathrm{X}^{*}$ \\
\hline
\end{tabular}

Quadro 56 - Respostas dos alunos cursando francês - sentimentos - Pergunta 8

Em relação aos sentimentos que a sala de aula pode despertar nos alunos cursando francês, no Quadro 56, é possível visualizar o que cada aluno escolheu. Pode ser verificado que três alunos (CF1, CF2 e CF4) selecionaram segurança; quatro alunos, constituindo todos os alunos cursando francês, (CF1, CF2, CF3 e CF4) selecionaram motivação; uma aluna (CF3) selecionou ansiedade; e uma aluna (CF4) selecionou outro, que foi explicado por ela como nervosismo/insegurança. Nenhum aluno selecionou medo. 


\begin{tabular}{|c|c|c|c|c|c|}
\cline { 2 - 6 } \multicolumn{1}{c|}{} & \multicolumn{5}{c|}{ Sentimentos } \\
\hline Alunos & Segurança & Motivação & Ansiedade & Medo & Outro \\
\hline FF1 & $\mathrm{X}$ & $\mathrm{X}$ & & & \\
\hline FF2 & & $\mathrm{X}$ & & & \\
\hline FF3 & $\mathrm{X}$ & $\mathrm{X}$ & $\mathrm{X}$ & & \\
\hline FF4 & & $\mathrm{X}$ & & & $\mathrm{X}^{*}$ \\
\hline
\end{tabular}

Quadro 57 - Respostas dos alunos formados em francês - sentimentos - Pergunta 8

No Quadro 57, pode-se verificar que dois alunos (FF1 e FF3) selecionaram segurança; quatro alunos (FF1, FF2, FF3 e FF4) selecionaram motivação; um aluno (FF3) selecionou ansiedade; e uma aluna (FF4) selecionou outro, que foi explicado por ela como diversão. Aqui também (Quadro 57), nenhum aluno selecionou medo.

Com os Quadros 56 e 57, vê-se que todos os alunos entrevistados que cursam francês e os que são formados em francês (oito alunos no total) têm um sentimento de motivação em relação à sala de aula.

Conforme Piaget (2014), o aluno que se sente motivado tem mais prazer para estudar e, consequentemente, aprende mais rápido do que aqueles que se sentem desmotivados de alguma forma.

Como visto na Seção 3.1 deste trabalho, a motivação é um dos principais pilares para a aprendizagem de uma língua e, conforme Brown (1987 apud BAGHIN, 1993), a motivação é a palavra que melhor explica o sucesso obtido na aprendizagem de língua estrangeira.

Por outro lado, nos dois grupos, houve dois alunos que marcaram ansiedade (CF3 e FF3), e a aluna CF4 ainda citou nervosismo e insegurança (Quadros 56 e $57)$.

Como mencionado na Seção 3.2 desta pesquisa, a ansiedade é um bloqueio que, além de causar insegurança e nervosismo, contribui fortemente para a desmotivação do aluno dentro de sala de aula, fazendo com que ela se torne um ambiente desconfortável e de apreensão.

Portanto, é de extrema importância que professores e alunos trabalhem juntos para que seja possível constituir um ambiente afetivo que transmita segurança e que motive os alunos o máximo possível. 
Pergunta 9 - De quais atividades aplicadas na aula de língua francesa você mais gosta/gostava?

\begin{tabular}{|c|l|}
\hline Alunos & \multicolumn{1}{c|}{ Respostas } \\
\hline CF1 & Imaginar situações e escrever sobre. \\
\hline CF2 & Áudios e exercícios. \\
\hline CF3 & Produção textual e exercícios orais de vocabulário. \\
\hline CF4 & Produção de texto, aulas de vocabulário e treino de compreensão oral. \\
\hline & Quadro 58 - Respostas dos alunos cursando francês - Pergunta 9
\end{tabular}

No Quadro 58, houve menção a diferentes tipos de atividades por parte dos alunos cursando francês, porém houve maior frequência em atividades de produção textual, compreensão oral e exercícios de vocabulário. Pode-se perceber que estas respostas entram em consonância com as respostas dadas por eles à Pergunta 5 (Quadro 48), em que os alunos cursando francês se diziam mais confortáveis com as habilidades de leitura (quatro menções), escrita (duas menções) e compreensão oral (uma menção).

As atividades preferidas dos alunos cursando francês assemelham-se mais às atividades propostas no método audiolingual, conforme visto na Seção 2.1 do presente trabalho.

\begin{tabular}{|c|l|}
\hline Alunos & \multicolumn{1}{c|}{ Respostas } \\
\hline FF1 & De cultura. Os testes de gramática, a conversação. \\
\hline FF2 & Discutir temas propostos. Nossos professores propunham temas polêmicos. \\
\hline FF3 & Jogos de perguntas sobre diferentes temas, letras de músicas e exposés. \\
\hline FF4 & Brincadeiras lúdicas e música. \\
\hline \multicolumn{2}{|c|}{ Quadro 59 - Respostas dos alunos formados em francês - Pergunta 9} \\
\hline
\end{tabular}

Quanto aos alunos formados em francês (Quadro 59), é possível analisar que eles, assim como os alunos cursando francês, mencionam diferentes atividades. Contudo, as atividades que envolvem produção oral (conversação, discussão de temas, jogos de perguntas) foram as mais mencionadas (três menções).

As respostas dos alunos formados em francês também entram em consonância com as respostas deles à Pergunta 5 (Quadro 49), em que esses alunos se mostraram mais confortáveis com a fala (três menções) e com a compreensão oral (duas menções). Essas atividades são típicas do método comunicativo, um dos métodos que mais obtém sucesso na aprendizagem de língua estrangeira, conforme visto na Seção 2.1 desta pesquisa.

Contudo, independente das atividades que os alunos preferem e/ou com que se sentem mais confortáveis, Tassoni (2012) aponta que a conduta do professor 
durante as atividades propostas deve ser de tranquilidade e encorajamento para que o aluno se sinta o mais confortável e motivado possível. Assim, cabe ao professor identificar a receptividade da sua turma em relação aos exercícios propostos.

Pergunta 10 - Você fala outros idiomas? Se sim, quais? Você acredita que falar outro idioma facilitou seu aprendizado de língua francesa? Por quê?

\begin{tabular}{|c|l|}
\hline Alunos & \multicolumn{1}{c|}{ Respostas } \\
\hline CF1 & Inglês. Me ajudou a entender a pronúncia das palavras em francês. \\
\hline CF2 & $\begin{array}{l}\text { Inglês e italiano. Saber inglês facilitou meu aprendizado no francês por ter } \\
\text { muitas palavras semelhantes. }\end{array}$ \\
\hline CF3 & $\begin{array}{l}\text { Inglês. Não sinto que o inglês facilita o aprendizado de francês, mas o francês } \\
\text { faz com que eu exercite o inglês. }\end{array}$ \\
\hline CF4 & $\begin{array}{l}\text { Inglês, espanhol, alemão e italiano. Acredito, por conta da proximidade com as } \\
\text { línguas latinas. }\end{array}$ \\
\hline \\
Quadro 60 - Respostas dos alunos cursando francês - Pergunta 10
\end{tabular}

No Quadro 60, todos os alunos cursando francês (100\% - quatro alunos) falam um idioma estrangeiro. Os alunos CF1, CF2 e CF4 (75\%) acreditam que falar outro idioma facilitou na aprendizagem do francês. A aluna CF3 (25\%) acredita que falar outro idioma (no caso, inglês) não facilitou a aprendizagem da língua francesa.

\begin{tabular}{|c|l|}
\hline Alunos & \multicolumn{1}{|c|}{ Respostas } \\
\hline FF1 & $\begin{array}{l}\text { Inglês. Se o francês tivesse sido meu primeiro idioma aprendido, eu teria mais } \\
\text { dificuldades. Muitas palavras são parecidas em ambos os idiomas. O inglês } \\
\text { facilitou muito o aprendizado de francês. }\end{array}$ \\
\hline FF2 & $\begin{array}{l}\text { Inglês. Com certeza facilitou pois já tinha passado por processos similares. Os } \\
\text { inícios são bastante parecidos e tendemos a ter medo ou vergonha. Mesmo que } \\
\text { os idiomas não sejam parecidos, os processos de aprendizagem são. }\end{array}$ \\
\hline FF3 & $\begin{array}{l}\text { Inglês. Atualmente estudo espanhol. Acredito que sim, consegui me desapegar } \\
\text { da língua materna, isso facilitou muito. }\end{array}$ \\
\hline FF4 & $\begin{array}{l}\text { Inglês. Não sei se isso ajuda no aprendizado de francês. Misturava os dois } \\
\text { idiomas, às vezes. }\end{array}$ \\
\hline
\end{tabular}

Quadro 61 - Respostas dos alunos formados em francês - Pergunta 10

No Quadro 61, todos os alunos (100\% - quatro alunos) falam um idioma estrangeiro. Três deles (75\% - FF1, FF2 e FF3) acreditam que falar outro idioma estrangeiro facilitou a aprendizagem de língua francesa. Apenas uma aluna $(25 \%$ FF4) diz não acreditar que isso tenha ajudado.

Levando em consideração o que foi proposto por Chomsky (1988) sobre a gramática universal (GU), os processos de aprendizagem de língua estrangeira são os mesmos; portanto, falar uma língua estrangeira facilita a aprendizagem da terceira, quarta, e assim por diante. 
Dessa forma, os alunos cursando francês e formados em francês podem ter se sentido mais confortáveis e confiantes para repetir este processo, porém talvez isso não tenha uma grande relação com a diminuição da ansiedade linguística (objeto de estudo deste trabalho), uma vez que este tipo de ansiedade é caracterizado por fatores externos e extralinguísticos.

Pergunta 11 (alunos cursando) - Você já estudou francês antes ou é a primeira vez? Se já, qual foi o motivo da desistência anteriormente?

\begin{tabular}{|c|l|}
\hline Alunos & \multicolumn{1}{|c|}{ Respostas } \\
\hline CF1 & Primeira vez. \\
\hline CF2 & Primeira vez. \\
\hline CF3 & Parei por falta de disponibilidade de horário e voltei a estudar um ano depois. \\
\hline CF4 & Primeira vez. \\
\hline \multicolumn{2}{|c|}{ Quadro 62 - Respostas dos alunos cursando francês - Pergunta 11 } \\
\hline
\end{tabular}

Três alunos (75\% - CF1, CF2 e CF4) afirmam estar aprendendo francês pela primeira vez. Apenas uma aluna (25\% - CF3) disse já ter desistido do idioma uma vez por falta de disponibilidade (Quadro 62).

Neste caso, o motivo que levou a aluna a desistir do curso foi um fator extralinguístico, que pode fazê-la se sentir desmotivada em relação à aprendizagem de uma forma geral, porém, como visto na Seção 3.2, a desmotivação é um bloqueio que pode despertar a ansiedade na aprendizagem de LE.

Pergunta 11 (formados em francês) - Você desistiu do curso em algum momento? Se sim, qual foi o motivo?

\begin{tabular}{|c|l|}
\hline Alunos & \multicolumn{1}{c|}{ Respostas } \\
\hline FF1 & Não. \\
\hline FF2 & Não. \\
\hline FF3 & Negativo. \\
\hline FF4 & Não. \\
\hline \multicolumn{2}{|c|}{ Quadro 63 - Respostas dos alunos formados em francês - Pergunta 11 } \\
\hline
\end{tabular}

No Quadro 63, os quatro alunos (100\%) entrevistados nunca desistiram do curso de língua francesa. Com isso, apesar de a ansiedade linguística ter sido identificada em algumas respostas dadas pelos alunos formados em francês, nenhum aluno se sentiu desmotivado a ponto de desistir do curso de língua francesa. Isso pode ser devido ao fato do bom relacionamento identificado entre professores e alunos, pois, conforme Almeida Filho (1993), citado na Seção 4.3 
desta pesquisa, a incompatibilidade de crenças entre alunos e professores pode fazer com que o ensino e a aprendizagem sejam dificultados, fazendo com que o aluno desista do curso.

\subsubsection{Inglês}

As respostas às perguntas feitas aos alunos de língua inglesa que participaram desta pesquisa serão analisadas nesta seção (5.2.2.2).

Os alunos de inglês, assim como os alunos de língua francesa, estão divididos em alunos cursando inglês e em alunos formados em inglês. Apesar de os alunos estarem separados nesses grupos, as perguntas feitas a eles foram as mesmas (com exceção da Pergunta 11), trocando apenas o tempo verbal como, por exemplo, acha/achava (presente do indicativo e pretérito imperfeito), que sempre será mencionado entre barras.

Contudo, as respostas de ambos os grupos serão analisadas juntas, por questões de simplicidade, inclusive a Pergunta 11, que, apesar de ter sido redigida de forma diferente para os grupos, tem o mesmo conteúdo.

Podem-se diferenciar as respostas dos grupos cursando e formados em inglês por meio dos títulos dos Quadros e também por meio das siglas que cada aluno recebeu ( $\mathrm{Cl} 1$ - cursando inglês 1; $\mathrm{Cl} 2$ - cursando inglês 2; $\mathrm{Cl} 3$ - cursando inglês 3; Cl4 - cursando inglês 4; Fl1 - formado em inglês 1; FI2 - formado em inglês 2; FI3 - formado em inglês 3; Fl4 - formado em inglês 4). Entretanto, a numeração contida nas siglas nada tem a ver com o nível de língua inglesa; serve somente para ordenar os alunos ( $\mathrm{Cl} 1$ - é o aluno 1 cursando inglês, e assim por diante).

Além disso, também são utilizadas siglas nas Pergunta 5 e 6, referentes às quatro habilidades linguísticas, que são L - Leitura; E - Escrita; F - Fala; e CO Compreensão Oral. 
Pergunta 1 - O que você acha/achava das aulas de inglês?

\begin{tabular}{|c|l|}
\hline Alunos & \multicolumn{1}{|c|}{ Respostas } \\
\hline Cl1 & Acredito que são boas. \\
\hline Cl2 & Essenciais e interessantes. \\
\hline Cl3 & Produtivas e essenciais. \\
\hline Cl4 & Amo. \\
\hline & Quadro 64 - Respostas dos alunos cursando inglês - Pergunta 1
\end{tabular}

No Quadro 64, todos os alunos cursando inglês ( $100 \%$ - quatro alunos) dizem gostar das aulas de língua inglesa.

\begin{tabular}{|c|l|}
\hline Alunos & \multicolumn{1}{c|}{ Respostas } \\
\hline Fl1 & Bem interessantes. \\
\hline FI2 & $\begin{array}{l}\text { No começo, achei interessante. Conforme foi passando o tempo, comecei a } \\
\text { achar monótono. }\end{array}$ \\
\hline FI3 & $\begin{array}{l}\text { Mistura de excitação e terror. No início, como eu não sabia muita coisa, me } \\
\text { sentia animado, mas tinha vergonha de errar e passar vergonha na frente de } \\
\text { outros alunos. No final, eu ficava animado porque sabia bastante coisa e queria } \\
\text { expor meu conhecimento, mas continuava com medo de cometer erros. }\end{array}$ \\
\hline Fl4 & $\begin{array}{l}\text { No início eu amava por ser algo novo, mas como era um curso longo, começou } \\
\text { a ficar cansativo e eu não consegui me dedicar tanto. }\end{array}$ \\
\hline \multicolumn{2}{|c|}{ Quadro 65 - Respostas dos alunos formados em inglês - Pergunta 1 }
\end{tabular}

No Quadro 65, pode-se ver que os alunos Fl1 e Fl2 achavam as aulas interessantes; contudo, o aluno $\mathrm{Fl} 2$ disse que as aulas ficaram monótonas com o passar do tempo. A aluna Fl4 compartilha do mesmo sentimento do aluno FI2 ao afirmar que amava as aulas no início, mas que ficaram cansativas ao longo dos anos. O aluno Fl3 aponta que se sentia desconfortável nas aulas, mas que com o passar do tempo, começou a se sentir mais animado, porém continuava com medo de cometer erros.

Com esses Quadros (64 e 65) é possível analisar que todos os alunos (oito) atribuíram palavras de valor positivo em relação às aulas, porém o grupo de alunos formados em inglês (Quadro 65), diferentemente do grupo dos alunos cursando inglês (Quadro 64), em sua maioria (FI2, Fl3 e Fl4), também atribuíram palavras de teor negativo como monótono, aterrorizante ("terror") e cansativo.

O aluno Fl3 (Quadro 65) ainda cita que "tinha vergonha de errar e passar vergonha na frente de outros alunos". Como visto na Seção 4.3 deste trabalho, Young (1991) afirma que os alunos adultos, em sua maioria, tentam preservar suas faces evitando cometer erros, pois, geralmente, acreditam não ter aptidão suficiente na LE. Com isso, sentem-se envergonhados, podendo despertar, dessa forma, a ansiedade na aprendizagem de língua estrangeira. 
Além disso, foi verificado que os alunos Fl2 e Fl3 apresentaram certa frustração em relação ao curso de inglês com o passar do tempo, que pode ser explicada pelos estudos de Horwitz (1985) em relação às expectativas irreais que os alunos têm acerca da aprendizagem de LE.

Muitos alunos podem achar que a aprendizagem é um processo rápido ou difícil demais; então, eles acabam se sentindo desmotivados e, como aponta Welp (2009), alunos desmotivados tendem a ficar com um filtro afetivo alto, ou seja, eles acabam não recebendo o input de forma integral.

Por outro lado, as respostas dos demais alunos (Cl1, Cl2, Cl3, Cl4 e Fl1 Quadros 64 e 65) entraram em consonância com o proposto por Allwright (2006) no que diz respeito à qualidade de vida dentro de sala de aula, visto que esses alunos atribuíram comentários como interessantes, essenciais e produtivas.

Pergunta 2 - Por que escolheu estudar inglês?

\begin{tabular}{|c|c|}
\hline Motivação & Totais \\
\hline Profissional & 3 \\
\hline Cultural & 1 \\
\hline Hobby & 0 \\
\hline
\end{tabular}

Quadro 66 - Respostas dos alunos cursando inglês - motivação - Pergunta 2

É possível perceber que houve três menções à motivação profissional e uma menção à motivação cultural por parte dos alunos cursando inglês (Quadro 66). Não houve nenhuma menção à motivação por hobby.

\begin{tabular}{|c|c|}
\hline Motivação & Totais \\
\hline Profissional & 2 \\
\hline Cultural & 2 \\
\hline Hobby & 0 \\
\hline
\end{tabular}

Quadro 67 - Respostas dos alunos formados em inglês - motivação - Pergunta 2

No Quadro 67, houve duas menções à motivação profissional e duas menções à motivação. Aqui também não houve nenhuma menção à motivação por hobby.

Ao todo, analisando os dois grupos (cursando inglês e formados em inglês), vê-se que houve maior ocorrência da motivação profissional, contendo cinco menções no geral. 
É interessante mencionar que, nesta pesquisa, a motivação dos alunos de francês (cursando e formados) foi bem diferente da motivação dos alunos de inglês (cursando e formados). Enquanto os alunos de inglês, em sua maioria (cinco menções), escolheram estudar inglês por uma motivação instrucional, os alunos de francês, também em sua maioria, escolheram estudar a língua francesa por hobby (cinco menções). Talvez isso se deva ao fato de que todos os alunos de francês entrevistados (oito alunos) já haviam estudado uma língua estrangeira anteriormente e, dentre elas, o inglês (Quadros 60 e 61).

\begin{tabular}{|c|l|}
\hline Alunos & \multicolumn{1}{|c|}{ Respostas } \\
\hline Cl1 & $\begin{array}{l}\text { Conhecimento necessário para me comunicar com outras pessoas de outros } \\
\text { países em viagens. }\end{array}$ \\
\hline Cl2 & $\begin{array}{l}\text { Essencial para minha futura profissão; é uma língua universal, facilitando a } \\
\text { comunicação em viagens. }\end{array}$ \\
\hline Cl3 & $\begin{array}{l}\text { Meu curso exige muitos artigos em inglês. Na graduação eu já passo perrengue } \\
\text { para trabalhos, seminários e estudos pessoais. Na área da saúde, acho } \\
\text { fundamental ter inglês. }\end{array}$ \\
\hline Cl4 & $\begin{array}{l}\text { Influência da minha mãe, ela dizia que é importante ter uma segunda língua } \\
\text { para arrumar um bom emprego. Fui desenvolvendo interesse no decorrer disso. }\end{array}$ \\
Quadro 68 - Respostas dos alunos cursando inglês - Pergunta 2
\end{tabular}

\begin{tabular}{|c|l|}
\hline Alunos & \multicolumn{1}{|c|}{ Respostas } \\
\hline FI1 & Sempre tive vontade de aprender a língua inglesa. \\
\hline FI2 & Meus pais me colocaram quando era muito novo, não tive muita escolha. \\
\hline FI3 & Interesse por músicas e filmes da língua. \\
\hline FI4 & $\begin{array}{l}\text { Foi uma decisão dos meus pais, era muito nova para escolher algo. Eles } \\
\text { achavam importante para o futuro ter uma segunda língua. }\end{array}$ \\
\hline
\end{tabular}

Quadro 69 - Respostas dos alunos cursando inglês - Pergunta 2

Nos Quadros 68 e 69, podem-se analisar por completo as respostas dos alunos cursando inglês e formados em inglês e, como já foi visto nos Quadros anteriores 66 e 67, há maior ocorrência da motivação profissional ao analisar os dois grupos juntos.

Como proposto por Ellis (1994), os alunos que procuram estudar uma língua estrangeira por motivos profissionais são dotados de uma motivação instrumental.

Sabe-se que a motivação é um dos principais fatores que contribui para o sucesso na aprendizagem de LE, como aponta Brown (1987), porém, por outro lado, para Gardner e Lambert (1959), os alunos que estudam uma língua estrangeira a partir de uma motivação instrumental estão mais propensos a se decepcionar, visto que eles têm um objetivo mais complexo em relação à LE. Com isso, esses alunos podem criar expectativas irreais acerca da aprendizagem e, dessa forma, se 
desmotivarem, assim como os alunos $\mathrm{Fl} 2$ e Fl4 se mostraram desmotivados ao responder à Pergunta 2 desta pesquisa.

Pergunta 3 - O que você acha/achava do seu professor de inglês?

\begin{tabular}{|c|l|}
\hline Alunos & \multicolumn{1}{c|}{ Respostas } \\
\hline Cl1 & $\begin{array}{l}\text { Em geral, são bons professores, porém nem todos aplicam o conteúdo de forma } \\
\text { igual. Alguns conduzem a aula em inglês, o que acredito ser bom, mas outros } \\
\text { falam português e inglês, o que considero ruim, mas entendo, pois nem todos } \\
\text { da classe têm o mesmo ritmo de aprendizado. }\end{array}$ \\
\hline $\mathbf{C l 2}$ & $\begin{array}{l}\text { Muito bom, por nos forçar a nos comunicarmos em inglês e por ter uma aula } \\
\text { bem dinâmica. }\end{array}$ \\
\hline $\mathbf{C l 3}$ & $\begin{array}{l}\text { Minha professora foi excelente. Além de ser didática, o bom relacionamento } \\
\text { com a turma fazia a hora da aula passar rápido e ser leve. }\end{array}$ \\
\hline $\mathbf{C l 4}$ & $\begin{array}{l}\text { Sempre gostei de todos. Acho todos muito autênticos e tornam o ensino mais } \\
\text { leve. O atual é legal, só peca em não se aprofundar nas explicações quando } \\
\text { alguém apresenta uma dúvida imediata. Fora isso, ele é legal e tranquilo, gosto } \\
\text { dele. }\end{array}$ \\
\hline
\end{tabular}

Quadro 70 - Respostas dos alunos cursando inglês - Pergunta 3

No Quadro 70, vê-se que todos os alunos (100\% - quatro alunos) disseram gostar de seus professores de inglês, tecendo elogios como bons, excelentes e autênticos. Por outro lado, os alunos $\mathrm{Cl} 1$ e $\mathrm{Cl} 4$, apesar de terem elogiado seus professores, fizeram uma crítica quanto à aplicação/explicação de conteúdo.

\begin{tabular}{|c|l|}
\hline Alunos & \multicolumn{1}{c|}{ Respostas } \\
\hline Fl1 & Competentes. Tive bons professores, dedicados e solícitos. \\
\hline FI2 & $\begin{array}{l}\text { Tive diversos professores. Achava que eles não estimulavam os alunos na } \\
\text { medida em que eu achava necessário. }\end{array}$ \\
\hline FI3 & $\begin{array}{l}\text { A maioria era exigente. Sentia uma mistura de medo e admiração. Medo porque } \\
\text { eram exigentes e eu estaria sujeito a decepcioná-los; admiração pelo fato de } \\
\text { saberem bastante, me instigava. }\end{array}$ \\
\hline Fl4 & $\begin{array}{l}\text { Gostava de todos. Eles sabiam passar o conteúdo de forma didática, aplicar em } \\
\text { situações do dia-a-dia e gerar conversas com o vocabulário, mesmo que a } \\
\text { metodologia do curso fosse engessada. }\end{array}$ \\
\hline
\end{tabular}

Quadro 71 - Respostas dos alunos formados em inglês - Pergunta 3

No Quadro 71, dois alunos (FI1 e Fl4) disseram ter gostado de seus professores. O aluno FI2 disse que não achava que seus professores estimulavam os alunos. Já o aluno $\mathrm{Fl} 3$ disse que a maioria de seus professores era exigente, fazendo com que sentisse medo.

Sabe-se que, com os estudos de Bekleyen (2004), os alunos esperam que o professor ofereça segurança a eles. Com isso, os alunos se sentem confortáveis e desenvolvem uma boa relação com seus professores. 
Quando o aluno FI3 afirma que os professores eram exigentes e que isso despertava medo nele, sua resposta torna-se consoante com o que foi proposto por Bekleyen (2004), que diz que muitos professores acreditam que o seu papel é ser exigente dentro de sala de aula, estabelecendo uma hierarquia. Entretanto, essa crença de alguns professores pode fazer com que seus alunos se sintam pressionados, com medo e, consequentemente, ansiosos. Com isso, é evidente que os professores dos alunos $\mathrm{Fl} 2$ e $\mathrm{Fl} 3$ não conseguiram exercer o papel de professores facilitadores.

Pergunta 4 - Para você, qual é/era a importância da relação professor-aluno para sua aprendizagem? Por quê?

\begin{tabular}{|c|c|}
\hline $\begin{array}{c}\text { Importância da } \\
\text { afetividade }\end{array}$ & Totais \\
\hline Importante & 4 \\
\hline Não é importante & 0 \\
\hline
\end{tabular}

Quadro 72 - Respostas dos alunos cursando inglês - afetividade - Pergunta 4

Observa-se que todos os alunos (quatro alunos) acreditam que a relação professor-aluno é importante (Quadro 72).

\begin{tabular}{|c|c|}
\hline $\begin{array}{c}\text { Importância da } \\
\text { afetividade }\end{array}$ & Totais \\
\hline Importante & 4 \\
\hline Não é importante & 0 \\
\hline
\end{tabular}

Quadro 73 - Respostas dos alunos formados em inglês - afetividade - Pergunta 4

No Quadro 73, pode-se perceber que todos os alunos formados em inglês (quatro alunos) acreditam na importância da afetividade professor-aluno.

\begin{tabular}{|c|l|}
\hline Alunos & \multicolumn{1}{|c|}{ Respostas } \\
\hline Cl1 & $\begin{array}{l}\text { Está na confiança, pois quando o professor leciona e delega atividades de } \\
\text { homework, por exemplo, se o aluno realmente tem interesse no aprendizado } \\
\text { pela língua, vai realizar os exercícios e questionar o professor caso tenha } \\
\text { dúvidas. }\end{array}$ \\
\hline $\mathbf{C l 2}$ & $\begin{array}{l}\text { Muito importante. O professor nos motiva a seguir em frente. Nos incentivando } \\
\text { mesmo que tenhamos dificuldades, o que é comum em quem aprende uma } \\
\text { língua mais tardiamente. }\end{array}$ \\
\hline $\mathbf{C l 3}$ & $\begin{array}{l}\text { Uma das coisas mais importantes no aprendizado é o professor que consegue } \\
\text { ter um bom relacionamento com o aluno, fazendo a matéria ser mais } \\
\text { interessante e fluir. }\end{array}$ \\
\hline $\mathbf{C l 4}$ & $\begin{array}{l}\text { Muito importante. Se o professor não for cativante, ele acaba cooperando no } \\
\text { desinteresse do aluno. Acredito que o que me prendeu nas aulas foram as } \\
\text { diferentes formas de ensino dos professores. }\end{array}$ \\
\hline
\end{tabular}




\begin{tabular}{|c|l|}
\hline Alunos & \multicolumn{1}{c|}{ Respostas } \\
\hline FI1 & $\begin{array}{l}\text { De extrema importância. Ajuda no desenvolvimento do aluno. Isso se o aluno } \\
\text { tiver interesse em aprender. Mas mesmo que o aluno tenha certa dificuldade, a } \\
\text { relação professor-aluno ajuda a estreitar a distância entre o aluno e suas } \\
\text { dificuldades. }\end{array}$ \\
\hline FI2 & $\begin{array}{l}\text { Bem grande. Os professores que mais tinham interação/confiança da turma } \\
\text { conseguiam estimular os alunos. Além de estimular os alunos a perder a } \\
\text { vergonha e o nervosismo na hora de falar. }\end{array}$ \\
\hline FI3 & $\begin{array}{l}\text { Extremamente importante. O aluno que tem uma boa relação com o professor é } \\
\text { mais capaz de absorver o conteúdo; possivelmente desenvolvendo um } \\
\text { interesse maior pela língua. }\end{array}$ \\
\hline FI4 & $\begin{array}{l}\text { Acho que deve haver uma hierarquia, mas não precisa ser algo autoritário. As } \\
\text { melhores relações são as que o professor consegue exercer o seu papel e } \\
\text { ainda ser amigo do aluno. Isso deixa a gente mais confortável de estar em sala } \\
\text { de aula. }\end{array}$ \\
\hline
\end{tabular}

Quadro 75 - Respostas dos alunos formados em inglês - Pergunta 4

Primeiramente, vale ressaltar que o termo "afetividade" não foi utilizado na Pergunta 4 de modo que isso não influenciasse a resposta dos alunos.

Nos Quadros 74 e 75, faz-se possível analisar as respostas completas dos grupos de alunos cursando inglês e formados em inglês.

Alguns alunos ( $\mathrm{Cl} 1$ e FI2 - Quadros 74 e 75) citaram a "confiança" que eles têm no professor como um fator determinante para o interesse e desempenho deles na aula. Como visto na Seção 4.3 do presente trabalho, o professor que ganha a confiança de seus alunos faz com que eles diminuam ou eliminem as crenças negativas que eles podem ter. Com isso, o aluno se sente mais interessado e motivado.

Além disso, os professores que transmitem confiança e deixam os alunos confortáveis, ou seja, os professores que estabelecem uma relação de afetividade conseguem fazer com que os alunos se sintam menos ansiosos, como aponta Tassoni (2012, p. 15 apud MORAIS, 2018) em um de seus estudos:

[...] as professoras atuavam com o objetivo de combater o excesso de ansiedade que surgia durante as atividades, buscando contagiar os alunos com sentimentos que tranquilizavam, encorajavam e fortaleciam-nos na execução das mesmas.

Com isso, ficou claro que os professores podem e devem criar uma atmosfera confortável e amigável dentro de sala de aula e ainda exercer seu papel com autoridade, como bem aponta a aluna FI4. 
Pergunta 5 - Com qual/quais dessas habilidades você se sente/sentia mais confortável: leitura, escrita, fala ou compreensão oral? Por quê?

\begin{tabular}{|c|c|}
\hline Habilidades & Totais \\
\hline L & 3 \\
\hline E & 0 \\
\hline F & 2 \\
\hline CO & 1 \\
\hline
\end{tabular}

Quadro 76 - Respostas dos alunos cursando inglês - conforto com as habilidades Pergunta 5

No Quadro 76, há três menções à leitura, duas menções à fala e uma menção à compreensão oral. Não há nenhuma menção à escrita.

Dessa forma, conclui-se que a maior parte dos alunos cursando inglês (três alunos) se sente mais confortável com a leitura.

\begin{tabular}{|c|c|}
\hline Habilidades & Totais \\
\hline L & 3 \\
\hline E & 2 \\
\hline F & 0 \\
\hline CO & 3 \\
\hline
\end{tabular}

Quadro 77 - Respostas dos alunos formados em inglês - conforto com as habilidades Pergunta 5

Há três menções à leitura, duas menções à escrita e três menções à compreensão oral. Não há nenhuma menção à fala (Quadro 77).

Assim, a maior parte dos alunos formados em inglês se sente mais confortável com a leitura e com a compreensão oral.

Vale ressaltar que houve mais menções (cinco, no todo) também por parte dos alunos cursando e formados em francês (Quadros 46 e 47), ou seja, parece haver uma preferência da maioria dos alunos entrevistados (Quadros 48, 49, 78 e 79 - CF1; CF2; CF3; CF4; FF1; Cl1; Cl2; Cl3; FI1; FI3; FI4) nesta pesquisa pela leitura, havendo 11 menções (Quadros 46, 47, 76 e 77), no todo.

\begin{tabular}{|c|l|}
\hline Alunos & \multicolumn{1}{|c|}{ Respostas } \\
\hline $\mathbf{C l 1}$ & $\begin{array}{l}\text { Leitura e fala. Uma das formas de aprender inglês de forma rápida está no } \\
\text { vocabulário; aprendendo o vocabulário, você aprende a ler e a falar. }\end{array}$ \\
\hline $\mathbf{C l 2}$ & $\begin{array}{l}\text { Leitura. Tenho mais facilidade de entender o que está escrito do que expressar } \\
\text { por meio escrito ou de fala o que quero dizer. }\end{array}$ \\
\hline $\mathbf{C l 3}$ & $\begin{array}{l}\text { Leitura. Sempre fui obrigada a entender textos em inglês por causa da } \\
\text { faculdade. Aprendi a decifrar muita coisa pelas palavras que já conhecia. }\end{array}$ \\
\hline $\mathbf{C l 4}$ & $\begin{array}{l}\text { Compreensão oral e fala. Amo falar em inglês, assistir filmes e séries, cantar. } \\
\text { Sempre me dei bem com a parte oral. }\end{array}$ \\
\hline
\end{tabular}


No Quadro 78, foi verificado que três alunos ( $\mathrm{Cl} 1, \mathrm{Cl} 2$ e $\mathrm{Cl} 3)$ mencionaram a leitura como a habilidade com que eles se sentem mais confortáveis.

Como visto na Seção 5.2.2.1 deste trabalho, no Quadro 48, os alunos cursando francês também preferiam a leitura e se concluiu que, como apontaram dois professores entrevistados nesta pesquisa (PF1 e PF2 no Quadro 25), geralmente, os alunos preferem a leitura porque não gostam de se expor e também não há criação intelectual por parte deles, já que é um processo passivo.

Apesar disso, o aluno Cl1 (Quadro 78) diz gostar da leitura e da fala, sendo a segunda um processo ativo em que o locutor é responsável pela criação de seu discurso; portanto, este aluno parece não se importar em preservar sua face neste quesito.

\begin{tabular}{|c|l|}
\hline Alunos & \multicolumn{1}{c|}{ Respostas } \\
\hline FI1 & $\begin{array}{l}\text { Leitura, escrita e compreensão oral. Escutava músicas em inglês, buscava as } \\
\text { letras em sites para ver a gramática e fonética, e assistia filmes com legendas } \\
\text { em inglês. }\end{array}$ \\
\hline FI2 & $\begin{array}{l}\text { Compreensão oral. Tenho hábito de assistir séries e filmes em inglês, peguei o } \\
\text { costume. }\end{array}$ \\
\hline FI3 & $\begin{array}{l}\text { Leitura e compreensão oral. Ler e ouvir uma mensagem já emitida é mais } \\
\text { confortável, só exige de mim uma reação intelectual. }\end{array}$ \\
\hline Fl4 & $\begin{array}{l}\text { Leitura e escrita. Leitura porque eu sabia o que tinha que falar, mesmo com o } \\
\text { risco de errar entonação/pronúncia. Escrita porque eu conseguia pensar antes } \\
\text { de escrever, e eu sabia que se algo estivesse errado só o professor iria ler. }\end{array}$ \\
\hline
\end{tabular}

No Quadro 79, assim como os alunos cursando inglês (Quadro 78), os alunos formados em inglês disseram que preferiam a leitura. Por outro lado, diferentemente dos alunos cursando inglês (Quadro 78), em que apenas um aluno ( $\mathrm{Cl} 4)$ menciona a $\mathrm{CO}$, há o mesmo número de menções (três) em relação à compreensão oral por parte dos alunos formados.

Contudo, nenhum aluno formado em inglês mencionou a fala como a habilidade que mais traz conforto a eles, o que pode indicar uma possível apreensão comunicativa, como indicam Horwitz, Horwitz e Cope (1986).

Analisando, então, ambos os grupos (cursando inglês e formados em inglês) de forma conjunta, percebe-se que houve seis menções ao todo em relação à leitura, podendo indicar que esses alunos se sentem mais confortáveis com o método audiolingual, que é voltado para leitura e vocabulário, conforme Leffa (2016). 
Pergunta 6 - Com qual/quais dessas habilidades você se sente/sentia mais confortável: leitura, escrita, fala ou compreensão oral? Por quê?

\begin{tabular}{|c|c|}
\hline Habilidades & Totais \\
\hline L & 0 \\
\hline E & 2 \\
\hline F & 2 \\
\hline CO & 1 \\
\hline
\end{tabular}

Quadro 80 - Respostas dos alunos cursando inglês - desconforto com as habilidades Pergunta 6

No Quadro 80, não há nenhuma menção à leitura, porém há duas menções à escrita, duas menções à fala e uma menção à compreensão oral como as habilidades que mais trazem desconforto aos alunos cursando inglês.

\begin{tabular}{|c|c|}
\hline Habilidades & Totais \\
\hline L & 0 \\
\hline E & 2 \\
\hline F & 3 \\
\hline CO & 0 \\
\hline
\end{tabular}

Quadro 81 - Respostas dos alunos formados em inglês - desconforto com as habilidades Pergunta 6

No Quadro 81, também não houve nenhuma menção à leitura, porém houve duas menções à escrita e três menções à fala como a habilidade em que os alunos formados em inglês mais se sentiam desconfortáveis. Não houve nenhuma menção à compreensão oral.

Em relação aos alunos de francês (cursando e formados - Quadros 50 e 51) também houve quatro menções à escrita, no todo. Com isso, pode-se perceber que ambos os grupos de alunos de língua inglesa e francesa se sentem desconfortáveis com a escrita de um modo geral, talvez pela necessidade de criação autoral.

\begin{tabular}{|c|l|}
\hline Alunos & \multicolumn{1}{|c|}{ Respostas } \\
\hline Cl1 & $\begin{array}{l}\text { Compreensão oral, pois essa habilidade exige treino de forma repetitiva. } \\
\text { Entender 100\% do que a pessoa fala de forma rápida é difícil. }\end{array}$ \\
\hline $\mathbf{C l 2}$ & $\begin{array}{l}\text { Escrita e fala. Tenho dificuldade de me expressar. Fico tão nervosa que as } \\
\text { palavras somem. }\end{array}$ \\
\hline $\mathbf{C l 3}$ & $\begin{array}{l}\text { Fala. Para conseguir montar uma frase, tenho que pensar e falar, fica muito } \\
\text { mais difícil do que passar para o papel, por exemplo, onde posso visualizar a } \\
\text { frase montada. }\end{array}$ \\
\hline $\mathbf{C l 4}$ & Escrita. Me perco e não consigo transmitir o que estou sentindo/pensando. \\
\hline
\end{tabular}




\begin{tabular}{|c|l|}
\hline Alunos & \multicolumn{1}{|c|}{ Respostas } \\
\hline FI1 & Fala. Tinha (tenho) uma certa dificuldade com a pronúncia de certas palavras. \\
\hline FI2 & $\begin{array}{l}\text { Escrita. Tinha costume de assistir séries e jogar jogos em inglês. O costume } \\
\text { com a língua veio de forma natural. A escrita era algo que utilizava menos, } \\
\text { acabava sendo o ponto menos desenvolvido. }\end{array}$ \\
\hline FI3 & $\begin{array}{l}\text { Escrita e fala. Existe uma reação prática e uma exposição que gerava dúvidas } \\
\text { sobre meu nível de entendimento e conhecimento, medo de errar e ansiedade. }\end{array}$ \\
\hline Fl4 & $\begin{array}{l}\text { Fala. Não conseguia pensar antes de responder. Me sentia pressionada e } \\
\text { julgada. }\end{array}$ \\
\hline
\end{tabular}

Quadro 83 - Respostas dos alunos formados em inglês - Pergunta 6

É possível verificar, nos Quadros 82 e 83, as respostas completas dos alunos cursando inglês e dos alunos formados em inglês à Pergunta 6.

Analisando os dois grupos juntos, há cinco menções à fala, quatro menções à escrita e apenas uma menção à compreensão oral. Percebe-se que a fala e a escrita estão em maioria e ambas as habilidades demandam uma responsabilidade de criação por parte dos alunos.

Ao citar a fala, alguns alunos (Cl2, Fl1, Fl3 e Fl4 - Quadros 82 e 83) utilizaram palavras como nervoso, dificuldade, medo, ansiedade, pressão e julgamento.

Como propõem Horwitz, Horwitz e Cope (1986) em relação à apreensão comunicativa, os alunos se sentem ansiosos com a prática da comunicação oral em língua estrangeira. Além disso, os autores também apontam que o medo da avaliação negativa também é causador de ansiedade, pois o aluno sente medo de ser julgado, como bem ilustra a aluna Fl4 ao dizer "me sentia pressionada e julgada" (Quadro 83).

Esse medo de se expor e ser avaliado, típico do aluno adulto, como aponta Alvarez e Bonfim (2008), deve-se ao fato de que os alunos adultos se cobram muito em vários aspectos da vida, incluindo a aprendizagem. Com isso, fica evidente que o medo de falar e se expor pode levar os alunos a vivenciar a ansiedade linguística.

Além da fala, houve quatro menções, no todo, em relação à escrita que, segundo Gomes e Pinheiro-Mariz (2011), é a última habilidade a ser completamente desenvolvida. Assim, o aluno pode se sentir pressionado durante essa atividade, pois ele pode achar que ainda não tem competência suficiente para exercê-la. 
Pergunta 7 - Como você se sente/sentia quando o professor faz/fazia perguntas em inglês diretamente a você?

\begin{tabular}{|c|c|}
\hline Alunos & Respostas \\
\hline Cl1 & $\begin{array}{l}\text { Acho ótimo, pois na aula é um dos poucos momentos em que é possível colocar } \\
\text { o conhecimento adquirido em prática. }\end{array}$ \\
\hline $\mathrm{Cl} 2$ & $\begin{array}{l}\text { Um pouco constrangida por não entender a pergunta ou não saber como } \\
\text { responder. }\end{array}$ \\
\hline $\mathrm{Cl} 3$ & Nervosa. \\
\hline $\mathrm{Cl} 4$ & $\begin{array}{l}\text { Tranquila. Quando não sei pronunciar ou esqueço uma palavra, eu sempre } \\
\text { pergunto. }\end{array}$ \\
\hline
\end{tabular}

Quadro 84 - Respostas dos alunos cursando inglês - Pergunta 7

Duas alunas $(\mathrm{Cl} 2$ e $\mathrm{Cl} 3)$ se mostraram desconfortáveis em relação às perguntas feitas diretamente a eles em inglês. Os outros dois alunos ( $\mathrm{Cl} 1$ e Cl4) se mostraram confortáveis com a situação (Quadro 84).

\begin{tabular}{|c|l|}
\hline Alunos & \multicolumn{1}{c|}{ Respostas } \\
\hline FI1 & $\begin{array}{l}\text { Ficava com vergonha pois me sentia inseguro com a pronúncia, não por estar } \\
\text { em sala de aula. }\end{array}$ \\
\hline FI2 & Tranquilo. \\
\hline FI3 & $\begin{array}{l}\text { Nos primeiros níveis, aterrorizado. Por mais que eu soubesse a resposta, me } \\
\text { senti muito inseguro. Nos níveis intermediários e avançados, dependendo de } \\
\text { como o professor era em relação à correção de erros, eu me sentia mais } \\
\text { confiante e disposto a encarar o medo. }\end{array}$ \\
\hline Fl4 & $\begin{array}{l}\text { Muito desconfortável. Sou extremamente tímida. Isso fazia a resposta e o } \\
\text { vocabulário desaparecerem porque eu achava que estava sendo julgada pela } \\
\text { turma, e errar na frente de todos seria motivo de piada. }\end{array}$ \\
\hline
\end{tabular}

Três alunos (FI1, Fl3 e Fl4) apontaram que se sentiam inseguros e desconfortáveis quando seus professores direcionavam perguntas em inglês diretamente a eles. Apenas um aluno (FI2) disse que se sentia tranquilo com a situação (Quadro 85).

Analisando ambos os grupos (alunos cursando inglês e formados em inglês), no total, cinco alunos dos oito entrevistados se sentem desconfortáveis com as perguntas feitas diretamente a eles. Os três alunos restantes se sentem bem com a interrogação.

Os alunos que se sentem desconfortáveis (Cl2, Cl3, FI1, Fl3 e Fl4 - Quadros 84 e 85) atribuíram palavras como "constrangida"; "nervosa"; "com vergonha"; "aterrorizado"; "inseguro"; e "muito desconfortável" para descrever o momento em que eles são questionados pelos professores.

Em relação à insegurança apontada pelos alunos FI1 e FI3 (Quadro 85), de acordo com Welp (2009), quando o aluno se sente inseguro e perde sua 
autoconfiança dentro de sala de aula, seu filtro afetivo aumenta consideravelmente, fazendo com que esse aluno não receba o input necessário. Dessa forma, por conta da ansiedade, o aluno pode achar que não está aprendendo e, assim, se sentir desmotivado.

No que diz respeito à aluna Fl4, que disse que "achava que estava sendo julgada pela turma, e errar na frente de todos seria motivo de piada", sua resposta é consoante com a teoria de Horwitz, Horwitz e Cope (1986), que revela que, entre os tipos de ansiedade linguística, o terceiro tipo de ansiedade seria o medo de avaliação negativa. Para os autores, a ansiedade de avaliação negativa é caracterizada pelo medo de ser julgado pelos outros alunos, como é possível perceber que é o caso da aluna Fl4.

Por outro lado, em relação à aluna $\mathrm{Cl} 2$, pode-se perceber a apreensão comunicativa, também postulada por Horwitz et al. (1986), pois o aluno sente medo de não entender o que outras pessoas, neste caso o professor, estão falando.

Todos esses traços são típicos da ansiedade linguística enfrentada por vários alunos dentro de sala de aula.

É importante ressaltar que dentre todos os alunos entrevistados nesta pesquisa (16 alunos), nove (CF1, CF4, FF1, FF4, Cl2, Cl3, Fl1, Fl3 e Fl4) não se sentem confortáveis em responder perguntas (Quadros 54, 55, 84 e 85).

Pergunta 8 - Qual/Quais sentimento(s) a sala de aula traz/trazia a você?

\begin{tabular}{|c|c|c|c|c|c|}
\cline { 2 - 6 } \multicolumn{1}{c|}{} & \multicolumn{5}{c|}{ Sentimentos } \\
\hline Alunos & Segurança & Motivação & Ansiedade & Medo & Outro \\
\hline Cl1 & $\mathrm{X}$ & $\mathrm{X}$ & $\mathrm{X}$ & & \\
\hline $\mathrm{Cl} 2$ & & $\mathrm{X}$ & & & \\
\hline $\mathrm{Cl} 3$ & & $\mathrm{X}$ & & & \\
\hline $\mathrm{Cl} 4$ & $\mathrm{X}$ & \multicolumn{5}{|c|}{} & & $\mathrm{X}^{*}$ \\
\hline
\end{tabular}

Quadro 86 - Respostas dos alunos cursando inglês - sentimentos - Pergunta 8

Quanto aos sentimentos despertados em sala de aula nos alunos cursando inglês, é possível analisar as opções que cada aluno escolheu (Quadro 86).

Dois alunos escolheram segurança ( $\mathrm{Cl} 1$ e Cl4); três alunos escolheram motivação ( $\mathrm{Cl}$ 1, $\mathrm{Cl}$ e e $\mathrm{Cl} 3)$; um aluno escolheu ansiedade (Cl1); nenhum aluno 
escolheu medo; e uma aluna (Cl4) escolheu outro, que foi explicado por ela como conforto (Quadro 86).

\begin{tabular}{|c|c|c|c|c|c|}
\cline { 2 - 6 } \multicolumn{1}{c|}{} & \multicolumn{5}{c|}{ Sentimentos } \\
\hline Alunos & Segurança & Motivação & Ansiedade & Medo & Outro \\
\hline Fl1 & $\mathrm{X}$ & $\mathrm{X}$ & & & \\
\hline Fl2 & & & & & $\mathrm{X}^{*}$ \\
\hline Fl3 & & & $\mathrm{X}$ & & \\
\hline Fl4 & & & $\mathrm{X}$ & & \\
\hline
\end{tabular}

Quadro 87 - Respostas dos alunos formados em inglês - sentimentos - Pergunta 8

No Quadro 87, é possível analisar que um aluno escolheu segurança (FI1); um aluno escolheu motivação (FI1); dois alunos escolheram ansiedade (FI3 e Fl4); nenhum aluno escolheu medo; e um aluno escolheu outro, que foi explicado por ele como tédio (FI2).

Em relação aos alunos cursando inglês (Quadro 86), apesar de um aluno (CI1) ter escolhido ansiedade, a maioria das opções marcadas foram segurança (duas menções) e motivação (três menções). Uma aluna (Cl4) ainda mencionou conforto.

Assim, como propõe Piaget (2014), este deve ser o ambiente em sala de aula que os professores devem proporcionar, um ambiente motivador, confortável, onde o aluno se sinta seguro para adquirir conhecimento.

Por outro lado, no grupo dos alunos formados em inglês (Quadro 87), houve mais menções à ansiedade (duas menções). Apenas um aluno (FI1) mencionou que se sente seguro e motivado. Além disso, o aluno Fl2 mencionou que sentia tédio nas aulas.

Conforme indica Finkelstein (1980, p. 119 apud SILVEIRA, 2012, p. 44) em relação às emoções dos indivíduos:

Os sentimentos individuais de sofrimento, ansiedade, tédio, distanciamento, amor, compaixão, e assim por diante são manifestações de apreensões particulares e pessoais que o indivíduo fez do mundo. Deste modo, as emoções são emblemáticas do entendimento do indivíduo de si mesmo, dos outros e do contexto social.

Assim, entende-se que as emoções dos alunos têm a ver com suas crenças, e as crenças, como visto na Seção 4.3, podem fazer com que a ansiedade dos alunos aumente, afetando diretamente a motivação deles em relação à aprendizagem de língua estrangeira. 
De modo geral, pode-se perceber que o sentimento mais citado pelos 16 alunos entrevistados nesta pesquisa foi motivação (12 menções - Quadros 56, 57, 86 e 87). Em relação à ansiedade, objetivo de estudo deste trabalho, houve menção por uma aluna cursando francês (CF3 - Quadro 56); um aluno formado em francês (FF3 - Quadro 57); um aluno cursando inglês (Cl1 - Quadro 86); e dois alunos formados em inglês (FI3 e Fl4 - Quadro 87).

Pergunta 9 - De quais atividades aplicadas na aula de língua inglesa você mais gosta/gostava?

\begin{tabular}{|c|l|}
\hline Alunos & \multicolumn{1}{c|}{ Respostas } \\
\hline Cl1 & Conversação, jogos online, apresentação de trabalho. \\
\hline Cl2 & $\begin{array}{l}\text { Leitura coletiva de textos que estão no livro. Atividades com colegas para } \\
\text { conversarmos em inglês. }\end{array}$ \\
\hline Cl3 & Conversas, elaboração de frases e apresentações. \\
\hline Cl4 & Jogos interativos e perguntas e respostas com um parceiro da turma. \\
\hline & Quadro 88 - Respostas dos alunos cursando inglês - Pergunta $\mathbf{9}$
\end{tabular}

No Quadro 88, houve menção a diferentes tipos de atividades por parte dos alunos cursando inglês. Contudo, houve maior frequência em relação à conversação, como eles mesmos citaram: "conversação"; "atividades com colegas para conversarmos em inglês"; "conversas e apresentações"; "perguntas e respostas com um parceiro da turma". Também foram citados jogos pelos alunos Cl1 e Cl4.

\begin{tabular}{|c|l|}
\hline Alunos & \multicolumn{1}{c|}{ Respostas } \\
\hline FI1 & Exercícios de listening. Atividade em grupo era bem legal também. \\
\hline FI2 & Debates em grupo. \\
\hline FI3 & Conversação em duplas. \\
\hline FI4 & $\begin{array}{l}\text { Músicas para todos cantarem juntos. Lembro perfeitamente a primeira música } \\
\text { que aprendi. Gostava também de jogos/batalhas. }\end{array}$ \\
\hline
\end{tabular}

Quadro 89 - Respostas dos alunos formados em inglês - Pergunta 9

No Quadro 89, também houve menção a diferentes tipos de atividades. O aluno Fl1 citou uma atividade de compreensão oral: "exercícios de listening". Outros dois alunos (FI2 e FI3) citaram a conversação: "debates em grupo"; "conversação em duplas". Já a aluna Fl4 citou jogos e músicas como suas atividades preferidas.

É perceptível que, em ambos os grupos analisados (cursando e formados), existe uma preferência pelas atividades da metodologia comunicativa.

Apesar de esses grupos terem dito, em sua maioria, que se sentem mais desconfortáveis com a fala na Pergunta 6 (Quadro 83), nesta Pergunta 9 (Quadro 89), eles se mostram mais receptivos com atividades que envolvam conversas com 
seus colegas de classe. Esses alunos se mostram mais desconfortáveis com a avaliação negativa do professor em si, como foi visto na Pergunta 7 (Quadro 85), do que com seus colegas de classe.

Contudo, como aponta Tassoni (2012), o professor deve encorajar os alunos nessas atividades, buscando ser dinâmico e propor atividades mais interativas, em que ele passe a ser o facilitador, inspirando os alunos.

Conforme Brown (2001), o professor deve deixar o papel de detentor do saber de lado e passar a ser o conselheiro de seus alunos, promovendo a interação de todos.

Pode-se perceber que os alunos cursando inglês e formados em inglês (Quadros 88 e 89) preferem atividades que envolvam conversação, assim como os alunos formados em francês (Quadro 59). Por outro lado, diferentemente deles, os alunos cursando francês preferem a produção textual (Quadro 58). Entretanto, de modo geral, pode-se dizer que a maior parte dos alunos entrevistados nesta pesquisa prefere o tipo de atividade que envolva conversas (nove menções).

Pergunta 10 - Você fala outros idiomas? Se sim, quais? Você acredita que falar outro idioma facilitou seu aprendizado de língua inglesa? Por quê?

\begin{tabular}{|c|l|}
\hline Alunos & \multicolumn{1}{c|}{ Respostas } \\
\hline Cl1 & Não. \\
\hline Cl2 & Espanhol. Não muito por serem línguas diferentes. \\
\hline Cl3 & Não. \\
\hline Cl4 & Não. \\
\hline & Quadro 90 - Respostas dos alunos cursando inglês - Pergunta 10 \\
\hline
\end{tabular}

Verifica-se que 75\% (três alunos) dos alunos cursando inglês não falam outro idioma. Apenas a aluna Cl2 (25\%) fala outro idioma, mas não acredita que isso tenha ajudado na aprendizagem de língua inglesa (Quadro 90).

\begin{tabular}{|c|l|}
\hline Alunos & \multicolumn{1}{c|}{ Respostas } \\
\hline Fl1 & $\begin{array}{l}\text { Espanhol. Quando comecei a estudar inglês, ainda não tinha aprendido outro } \\
\text { idioma. }\end{array}$ \\
\hline Fl2 & Não. \\
\hline Fl3 & Não. \\
\hline Fl4 & Espanhol. Mas fiz o curso de inglês primeiro. \\
\hline \multicolumn{2}{|c|}{ Quadro 91 - Respostas dos alunos formados em inglês - Pergunta 10} \\
\end{tabular}

No Quadro 91, observa-se que nenhum dos alunos (quatro) falava outro idioma quando faziam o curso de inglês. 
Com isso, não foi possível analisar se o processo de aprendizagem de língua estrangeira foi facilitado, como propõe a teoria da GU de Chomsky (1988), no caso dos alunos cursando inglês e formados em inglês.

Como foi constatado nos Quadros 60 e 61, todos os alunos de francês (oito alunos) já falavam um idioma estrangeiro, o que pode ter feito com que eles se sentissem mais confiantes que os alunos de inglês para aprender uma nova língua (dos oito alunos de inglês entrevistados, apenas um - $\mathrm{Cl} 2$ - falava outro idioma Quadros 90 e 91).

Pergunta 11 (cursando) - Você já estudou inglês antes ou é a primeira vez? Se já, qual foi o motivo da desistência anteriormente?

\begin{tabular}{|c|l|}
\hline Alunos & \multicolumn{1}{|c|}{ Respostas } \\
\hline Cl1 & Não. \\
\hline Cl2 & Primeira vez. \\
\hline Cl3 & Primeira vez. \\
\hline Cl4 & Primeira vez. \\
\hline & Quadro 92 - Respostas dos alunos cursando inglês - Pergunta 11
\end{tabular}

No Quadro 92, é possível verificar que todos os alunos (quatro) estão estudando inglês pela primeira vez, não havendo nenhuma desistência.

Pergunta 11 (formados) - Você desistiu do curso em algum momento? Se sim, qual foi o motivo?

\begin{tabular}{|c|l|}
\hline Alunos & \multicolumn{1}{c|}{ Respostas } \\
\hline FI1 & Não. \\
\hline FI2 & Não. \\
\hline FI3 & Não. \\
\hline FI4 & Sim. Quando reprovei. \\
\hline
\end{tabular}

Quadro 93 - Respostas dos alunos formados em inglês - Pergunta 11

Foi verificado que três alunos (FI1, FI2 e FI3) nunca desistiram do curso. Apenas uma aluna (FI4) diz ter desistido quando foi reprovada (Quadro 93).

Constata-se que apenas uma aluna de francês (CF3 - Quadro 62) também desistiu do curso, porém a desmotivação foi por falta de tempo, diferentemente da aluna FI4. É evidente que a aluna Fl4 se sentiu desmotivada a ponto de desistir do curso de inglês em algum momento.

Conforme Welp (2009), o aluno pode ver a aula de língua estrangeira como um lugar onde suas fraquezas são reveladas, ou seja, o aluno perde a autoconfiança. Como visto na Seção 3.2, a desmotivação é um dos maiores 
bloqueios que levam à ansiedade, assim interferindo diretamente na aprendizagem de LE do aluno.

Em relação aos demais alunos, apesar de terem mostrado ser alunos ansiosos em algumas perguntas desta análise, nenhum deles se sentiu desmotivado ao ponto de desistir do curso de inglês e, talvez, isso seja devido ao fato de que eles mantêm um bom relacionamento com seus professores, como foi visto nas respostas às Perguntas 3 e 4 (Quadros 70, 71, 74 e 75).

Com isso, conclui-se que os alunos estão sujeitos a passar por momentos de dificuldade e ansiedade em sala de aula de LE, porém, com exceção de fatores que envolvem problemas pessoais e familiares, o professor é capaz de ser a figura afetiva, que faz com que seus alunos vejam a sala de aula como um ambiente seguro e motivador. Além disso, a afetividade não é benéfica somente para a vida do aluno, mas também para a vida do professor, que é o responsável por transmitir seu conhecimento em sala de aula. Um professor autoconfiante e livre de crenças negativas é um professor amigo, disposto a encorajar seus alunos. 


\section{CONCLUSÃO}

Este trabalho teve como objetivo observar as possíveis influências negativas da ansiedade durante o processo de aprendizagem de língua estrangeira (inglês e francês, especificamente). Além disso, foi possível investigar a afetividade como auxílio à ansiedade na aprendizagem de LE.

Nenhuma solução foi adotada previamente para esta questão; portanto, este trabalho destinou-se a fazer uma pesquisa reflexiva e buscar entender, por meio dos questionários aplicados a professores e alunos de escolas de idiomas públicas e privadas, como a ansiedade pode contribuir para o insucesso da aprendizagem de língua estrangeira. Entretanto, com a vasta pesquisa bibliográfica e a análise de dados obtidos dos questionários, observou-se ainda a influência negativa das crenças e da falta de afetividade no processo de ensino-aprendizagem. Portanto, a afetividade mostrou-se uma possível aliada para a manutenção da ansiedade em sala de aula.

A pesquisa de campo foi implementada em diferentes escolas de idiomas (públicas e privadas), a fim de investigar os aspectos relevantes referentes à ansiedade. Os questionários para a coleta de dados foram entregues a professores e alunos, sendo, assim, possível compreender melhor como o sentimento da ansiedade é instalado no ambiente escolar.

Primeiramente, serão apresentadas as conclusões relativas ao desconforto com as habilidades linguísticas. Além disso, serão analisados os sentimentos despertados nos alunos dentro do ambiente de sala de aula. Depois, será possível observar a identificação dos alunos ansiosos por parte dos professores e, por fim, a importância do bom relacionamento entre professor e aluno segundo a opinião deles.

A partir das respostas dos professores, foi possível concluir que $75 \%$ de todos os quatro professores (três - PF1, PF2 e PI1) acreditam que a fala é a habilidade linguística que mais traz desconforto aos alunos (Quadro 23 - Seção 5.2.1). (Ver Gráfico 1). 


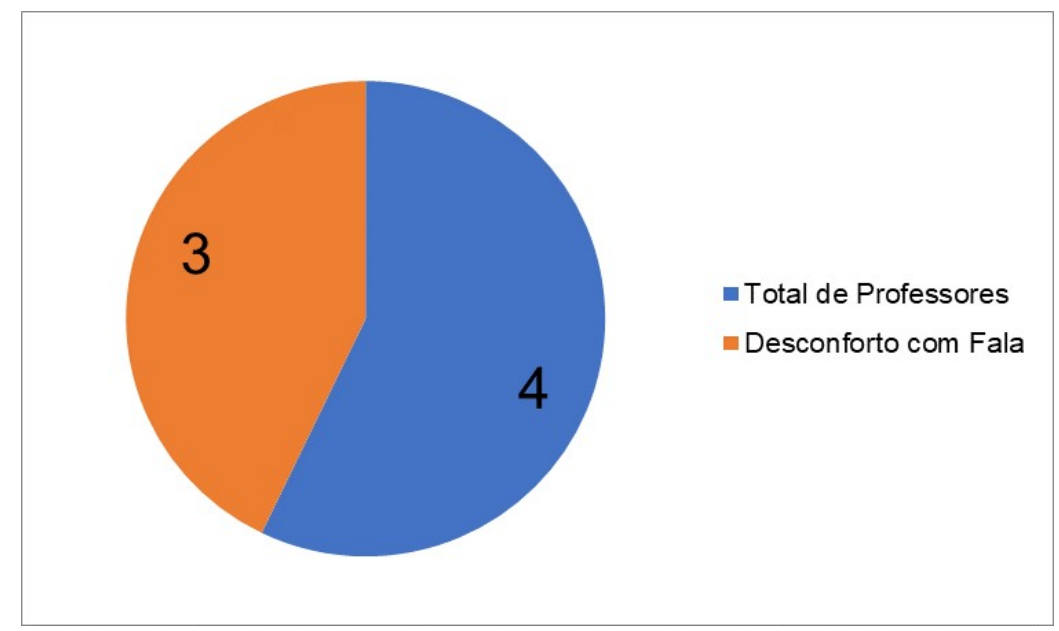

Gráfico 1 - Desconforto com as habilidades segundo os professores de francês e inglês

Por parte dos alunos de francês (cursando e formados - oito no total), houve três menções à fala (alunos CF1, CF2 e CF4) e quatro menções à escrita (alunos CF2, FF1, FF2 e FF3) - Quadros 52 e 53 - Seção 5.2.2.1 -, como sendo as habilidades mais desconfortáveis. Em relação aos alunos de inglês (cursando e formados - oito no total), houve cinco menções à fala (alunos $\mathrm{Cl} 2, \mathrm{Cl} 3, \mathrm{FI}$, $\mathrm{Fl} 3$ e Fl4) e quatro menções à escrita (alunos Cl2, Cl4, FI2 e FI3) - Quadros 82 e 83 Seção 5.2.2.2 -, também em relação ao desconforto com as habilidades linguísticas. (Ver Gráficos 2 e 3).

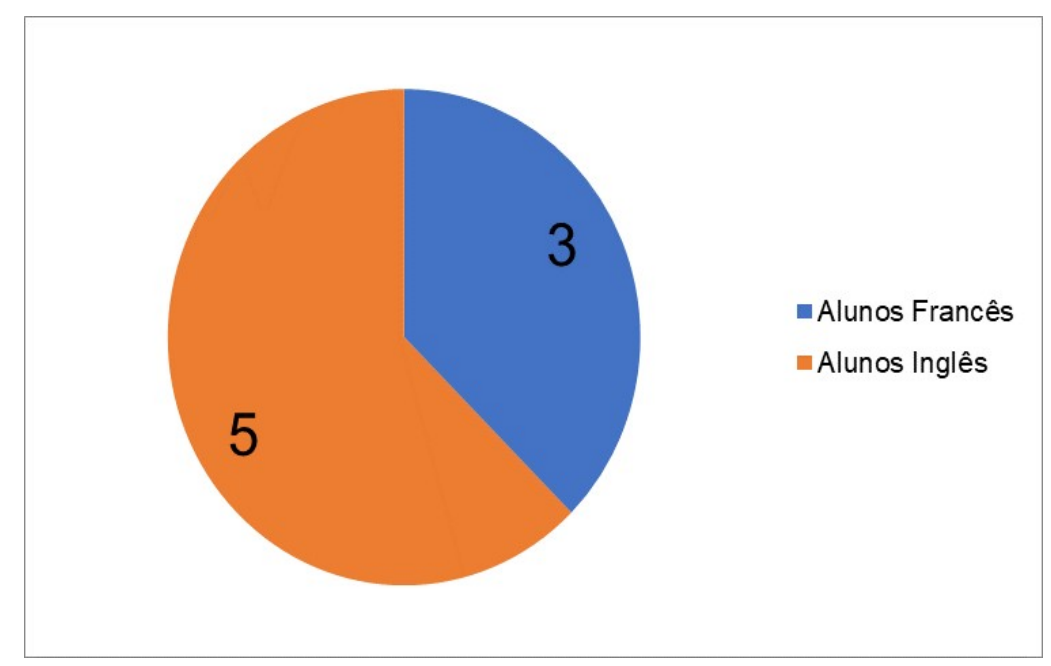

Gráfico 2 - Desconforto com a fala segundo os alunos de francês e inglês 


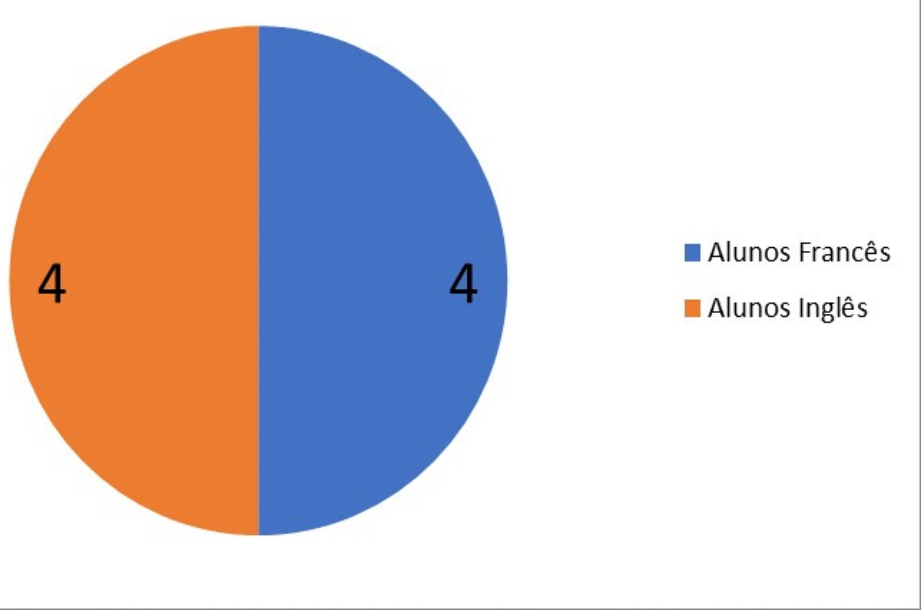

Gráfico 3 - Desconforto com a escrita segundo os alunos de francês e inglês

Com isso, em resumo, além de serem um desconforto que é percebido também pelos professores, é possível constatar que, dos 16 alunos entrevistados, oito (CF1, CF2, CF4, Cl2, Cl3, Fl1, Fl3 e Fl4) mencionaram a fala e oito (CF2, FF1, FF2, FF3, Cl2, Cl4, Fl2 e Fl3) mencionaram a escrita como motivos de vulnerabilidade em sala de aula (Quadros 52, 53, 82 e 83 - Seções 5.2.2.1 e 5.2.2.2). Como apontam os estudos de Horwitz, Horwitz e Cope (1986), já mencionados na Seção 4.1 deste trabalho, um dos tipos de ansiedade em sala de aula é a apreensão comunicativa. O aluno sente medo de falar e/ou de não compreender o discurso de outras pessoas. Por sua vez, em relação ao desconforto com a escrita, a teoria de Gomes e Pinheiro-Mariz (2011), propõe que a escrita é a última habilidade a ser desenvolvida nos alunos; portanto, eles se sentem desconfortáveis quando a produção escrita está em um nível desproporcional ao conhecimento de língua deles.

Além disso, nesta pesquisa, entre todos os 16 alunos entrevistados, houve nove menções, no total, (CF1, CF4, FF1, FF4, Cl2, Cl3, Fl1, Fl3 e Fl4) ao desconforto em responder perguntas diretamente na língua estrangeira, sendo quatro das menções por alunos de francês e cinco das menções por alunos de inglês (ambos cursando e formados), como foi visto nos Quadros 54, 55, 84 e 85 das Seções 5.2.2.1 e 5.2.2.2. (Ver Gráfico 4). 


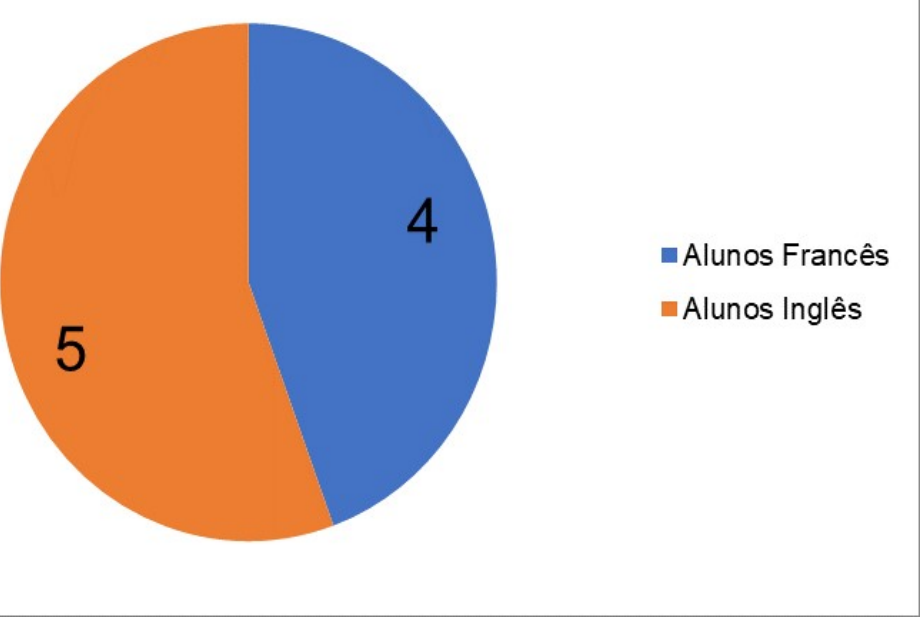

Gráfico 4 - Desconforto em responder perguntas segundo os alunos de francês e inglês

No que concerne aos sentimentos despertados nos alunos em sala de aula, de todos os 16 alunos entrevistados, houve 12 menções (CF1, CF2, CF3, CF3, FF1, FF2, FF3, FF4, Cl1, Cl2, Cl3 e FF1), no todo, à motivação, oito por parte dos alunos de francês e quatro por parte dos alunos de inglês - cursando e formados (Quadros 56, 57, 86 e 87 - Seções 5.2.2.1 e 5.2.2.2). (Ver Gráfico 5).

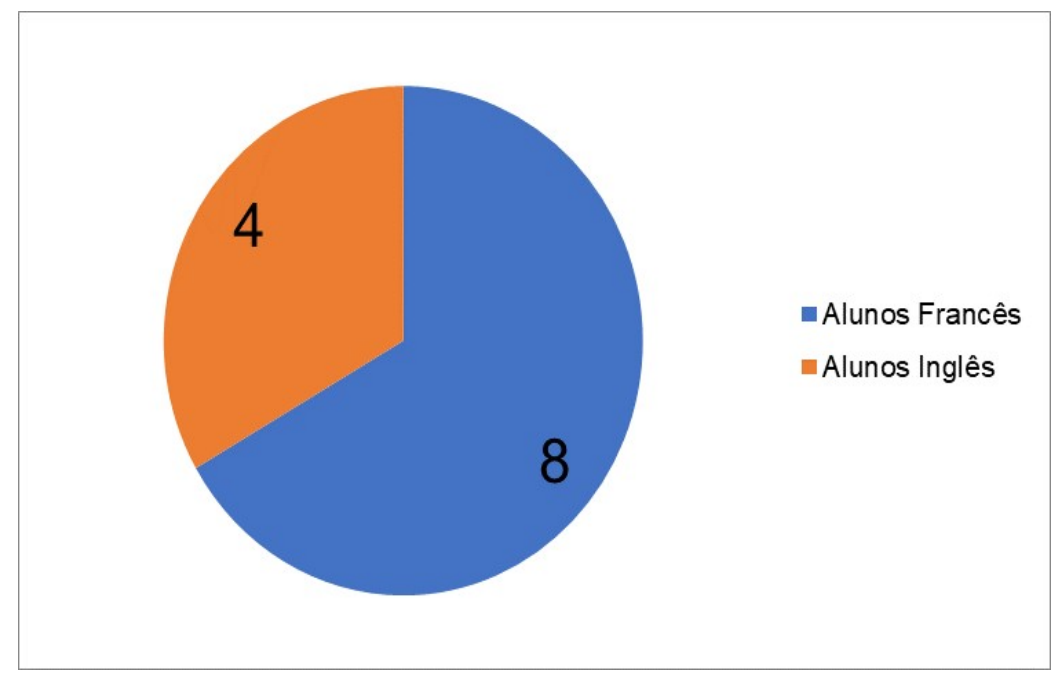

Gráfico 5 - Sentimento de motivação segundo os alunos de francês e inglês

De acordo com Costa e Souza (2003), a motivação é um processo que ocorre internamente, porém são necessários estímulos externos para despertar o interesse do aluno. Além disso, as autoras afirmam que não há aprendizagem sem motivação; todavia, a motivação sozinha não é suficiente para o sucesso da aprendizagem de LE. 
Em contrapartida, de todos os 16 alunos entrevistados, houve cinco menções (CF3, FF3, Cl1, Fl3 e Fl4 - Quadros 56, 57, 86 e 87 - Seções 5.2.2.1 e 5.2.2.2) à ansiedade, duas delas por parte de alunos de francês e três por parte de alunos de inglês - cursando e formados. (Ver Gráfico 6).

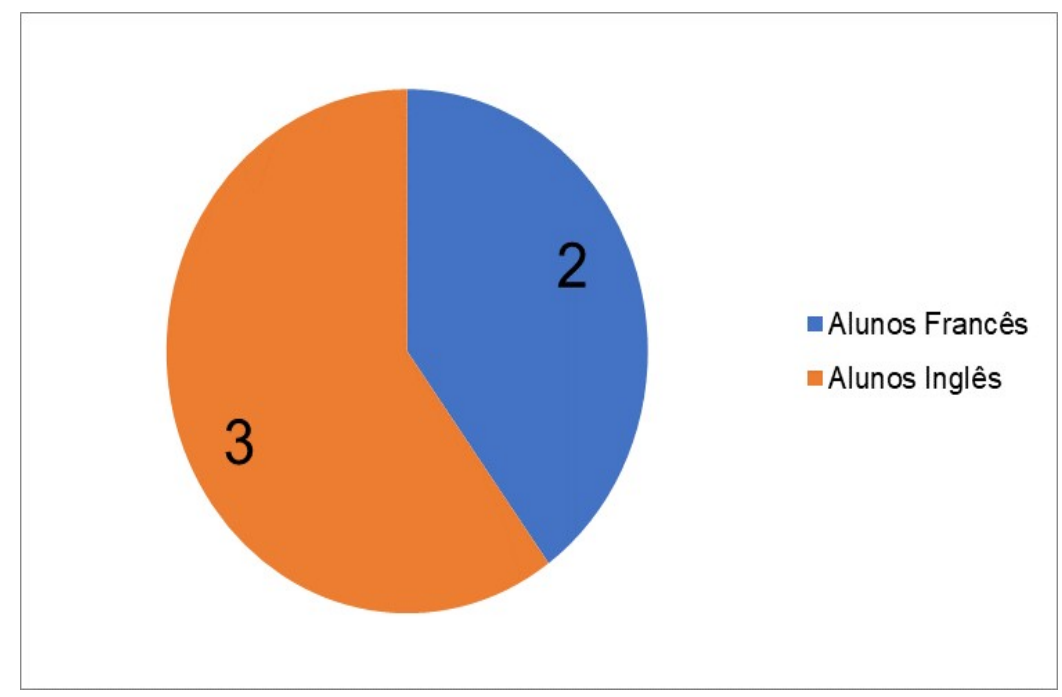

Gráfico 6 - Sentimento de ansiedade segundo os alunos de francês e inglês

Este é um número significativo quando a aprendizagem é colocada em questão, visto que a ansiedade foi gerada em diferentes línguas e níveis de aprendizado. Mesmo que talvez os alunos ansiosos não estejam em grande número nas salas de aula, o aluno que sofre com este problema deve ser compreendido e auxiliado. De acordo com Camargo (2009, p. 15):

\begin{abstract}
A ansiedade escolar envolve aspectos relacionados à identificação das fontes que causam tensão para os alunos, quais os seus efeitos sobre a aprendizagem, quais os alunos mais afetados e as formas de tratamento. As pesquisas demonstram que a ansiedade pode ser despertada tanto em disciplinas específicas (matemática, estatística, entre outras), como em situações que envolvem algum tipo de avaliação, como exames ou testes. A intensidade da ansiedade pode variar de níveis imperceptíveis até níveis extremamente elevados, perturbando o funcionamento cognitivo.
\end{abstract}

Portanto, conclui-se que é imprescindível que os alunos que sofrem de ansiedade na aula de língua estrangeira devem ser auxiliados pelos professores e pela escola, de alguma forma. Assim, a partir dos dados obtidos com este trabalho, foi possível inferir que, entre os professores entrevistados (quatro), 75\% (três - PF1, PF2 e PI1) sabiam identificar seus alunos ansiosos (Quadro 30 - Seção 5.2.1). A professora restante $(25 \%$ - PI2) disse não identificar nenhum aluno ansioso naquele momento; porém, como aponta Camargo (2009), a ansiedade pode ser instalada num nível imperceptível para aqueles que não a vivenciam. (Ver Gráfico 7). 


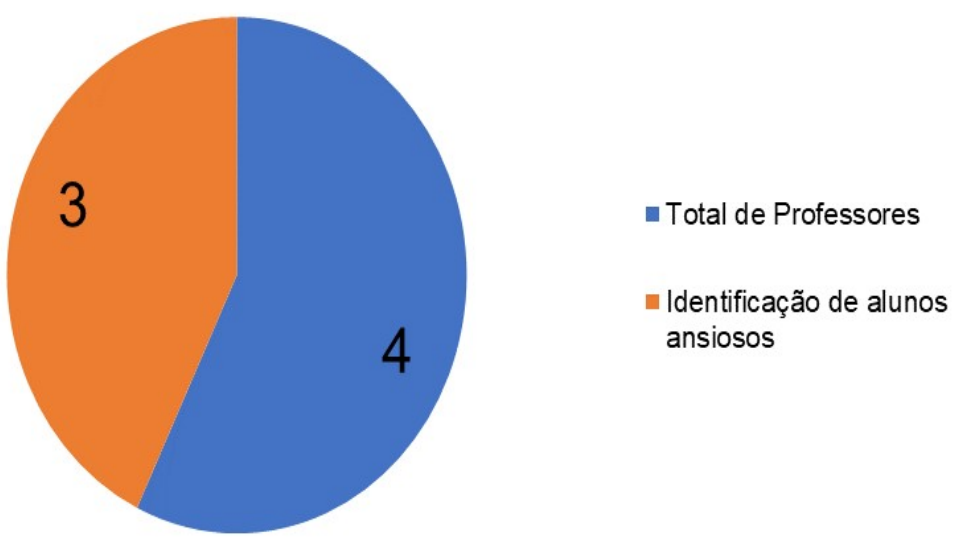

Gráfico 7 - Identificação de alunos ansiosos segundo os professores de francês e inglês

Ademais, quando levantada a questão da importância da afetividade entre professor e aluno, todos os participantes desta pesquisa (20, no total - professores e alunos) afirmaram que este é um fator importante no processo de ensinoaprendizagem (Quadros 26, 27, 44, 45, 74 e 75 das Seções 5.2.1; 5.2.2.1; e 5.2.2.2). Além disso, ao desenvolverem suas respostas, os professores PF1 e PI2 (Quadros 26 e 27 da Seção 5.2.1) disseram acreditar que a afetividade desempenha um papel de auxílio à motivação. Ainda segundo Camargo (2009, p. 15):

\footnotetext{
Alguns fatores mais específicos relacionados à escola podem também contribuir para o desenvolvimento da ansiedade e afetar a aprendizagem. A forma como o professor interage com seus alunos, o ambiente em sala de aula, a avaliação com características ameaçadoras, escolas que incentivam a competição e a comparação social, o valor crescente atribuído às notas.
}

Portanto, como também visto no decorrer da Seção 4.2 desta pesquisa, conclui-se que a afetividade pode melhorar a qualidade das aulas e do convívio, contribuindo, assim, diretamente como auxílio à ansiedade. Professores e alunos que mantêm um bom relacionamento tornam-se mais motivados e empenhados em ensinar/aprender.

Com isso, levando em consideração a importância da identificação e da manutenção da ansiedade na aprendizagem de língua estrangeira, esta pesquisa resultou em apoio documental para professores e alunos de língua estrangeira, profissionais da área da educação de modo geral e tradutores, cuja principal ferramenta de trabalho é a língua estrangeira. Além da extensa lista de referências bibliográficas, também foi possível registrar a opinião e os sentimentos de professores e alunos por meio da análise realizada acerca do tema ansiedade. 
Faz-se necessário avaliar a importância do tema discutido neste trabalho, levando, ainda, em consideração os avanços dos estudos de psicolinguística. Espera-se que pesquisas mais abrangentes possam ser realizadas futuramente, abrangendo mais professores e alunos. Sugere-se ainda realizar trabalhos futuros em escolas de diferentes estados do Brasil e/ou em escolas de língua estrangeira em países de língua inglesa e/ou países francófonos. 


\section{REFERÊNCIAS BIBLIOGRÁFICAS}

AIDA, Y. Examination of Horwitz, Horwitz and Cope's construct of foreign language anxiety: The case of students of Japanese. Modern Language Journal, v. 78, 1994. p. $155-168$.

ALLWRIGHT, R. L. Six promising directions in Applied Linguistics. In: GIEVE, S.; MILLER, I. (Eds.). Understanding the language classroom. New York: Palgrave/McMillan, 2006.

ALMEIDA FILHO, José Carlos Paes de. Dimensões Comunicativas no ensino de línguas. Campinas, SP: Pontes Editora, 1993.

ALVAREZ, Maria Luisa Ortiz; BONFIM, Elisabeth Rodrigues. A cultura de aprender LE (inglês) de alunos adultos na faixa etária de 40 a 65 anos. In: SILVA, Kleber Aparecido da; ALVAREZ, Maria Luisa Ortiz. Perspectivas de investigação em Linguística Aplicada. Campinas, SP: Pontes, 2008.

ANDERSEN, Roberto. A afetividade na Educação: psicopedagogia. São Paulo: All Print, 2009.

BAGHIN, Débora C. Mantelli. A motivação para aprender língua estrangeira em contexto de ensino interdisciplinar. Biblioteca Central, UNICAMP, 1993.

Disponível em:

<http://repositorio.unicamp.br/sspui/bitstream/REPOSIP/269408/1/Baghin_DeboraCri stinaMantelli_M.pdf>. Acesso em: 5 abr. 2020.

BARCELOS, Ana Maria Ferreira. A Cultura de aprender língua estrangeira (inglês) de alunos formandos de letras. 1995. 140, LI f. Dissertação (mestrado) Universidade Estadual de Campinas, Instituto de Estudos da Linguagem, Campinas, SP. Disponível em: <http://www.repositorio.unicamp.br/handle/REPOSIP/269102>. Acesso em: 5 abr. 2020.

BALBONI, P. Educazione bilíngue. Guerra-Soleil: Perugia, Itália: 1998.

BAUMAN, Z. Tempos líquidos. Rio de Janeiro: Zahar, 2007.

BEKLEYEN, Nilüfer. The Influence of Teachers and Peers on Foreign Language Classroom Anxiety. English Language Teaching Department - Dicle University, Turquia, 2004. p. 46-66. Disponível em:

$<$ https://www.researchgate.net/publication/270547258_THE_INFLUENCE_OF_TEA CHERS_AND_PEERS_ON_FOREIGN_LANGUAGE_CLASSROOM_ANXIETȲ_OG RETMEN__VE_SINIF_ARKADASLARININ_YABANCI_DIL_SINIF_KAYYGISI_UZËRIN DEKI_ETKILERI>. Ačesso em: 7 mar. 2020.

BOGAARDS, Paul. Aptitude et affectivité dans l'apprentissage des langues étrangères. Paris: Hatier, 1998.

BREEN, M. P. The social context for language learning - a neglected situation? Studies in Second Language Acquisition, v. 7, 1985. p. 135-158. 
BRITISH COUNCIL. Instituição cultural pública do Reino Unido. Disponível em: $<$ https://www.britishcouncil.org.br/quadro-comum-europeu-de-referencia-paralinguas-cefr>. Acesso em: 31 maio 2020.

BROWN, H. D. Principles of Language Learning and Teaching, 2. ed. Englewood Cliffs, New Jersey: Prentice Hall, 1987.

. Teaching by principles: an interactive approach to language pedagogy. New York: Longman, 2001.

BRUN, Milenna. Dificuldades na aprendizagem de línguas e meios de intervenção. Sitientibus, Feira de Santana, v. 29, 2003. p. 105-107 Disponível em: <http://www2.uefs.br:8081/sitientibus/pdf/29/dificuldades_na_aprendizagem_de_ling uas.pdf>. Acesso em: 11 abr. 2020.

CAMARGO, Eduardo Vieira. A ansiedade e seus efeitos na aprendizagem. Universidad de Léon, España, 2009. Disponível em:

$<$ https://www.academia.edu/12591777/A_ansiedade_e_seus_efeitos_na_aprendizag em>. Acesso em: 29 fev. 2020.

CESTARO, S. A. M. O ensino de língua estrangeira: história e metodologia. 2004. Disponível em: <http://www.hottopos.com/videtur6/selma.htm>. Acesso em: 28 mar. 2020.

CHAGAS, R.; Valnir C. Didática especial de línguas modernas. São Paulo: Companhia Editora Nacional, 1957.

CHOMSKY, A. N. Lectures on Government and Binding. Dordrecht: Foris Publications, 1988.

CORTAZZI, M.; JIN, L. Cultures of learning: Language classrooms in China. In: COLEMAN, H. (Org.). Society and the language classroom Cambridge: Cambridge University Press, 1996. p. 169-203.

COSTA, Elvira Livonete; SILVA, Karla Nunes. Fatores que motivam e desmotivam na aprendizagem da língua inglesa. Universidade Estadual de Goiás, 2003. Disponível em: <https://www.monografias.com/pt/trabalhos-pdf/fatores-motivamaprendizagem-lingua-inglesa/fatores-motivam-aprendizagem-lingua-inglesa.shtml>. Acesso em: 5 abr. 2020.

Dicionário Brasileiro da Língua Portuguesa. Editora Melhoramentos: SP, 2020. Disponível em: <https://michaelis.uol.com.br/moderno-portugues/busca/portuguesbrasileiro/ansiedade/>. Acesso em: 29 fev. 2020.

ELLIS, R. The study of second language acquisition. London: Oxford University Press, 1994. 
FÉLIX, Ademilde. Crenças de duas professoras de uma escola pública sobre o processo de aprender língua estrangeira. In: ALMEIDA FILHO, José Carlos Paes. 0 Professor de língua estrangeira em formação. Campinas, SP: Pontes Editora, 1999. p. 93-110.

FERNANDES, Karina Aires. A aprendizagem de línguas estrangeiras na idade adulta: fatores envolventes. PUCPR, 2011. Disponível em:

<https://educere.bruc.com.br/CD2011/pdf/4730_3106.pdf>. Acesso em: 11 abr. 2020.

FINKELSTEIN, J. Considerations for a sociology of the emotions. Studies in Symbolic Interaction, vol. 3, 1980. p. 111-121.

GARDNER, R. C. The socio-educational model of second-language learning:

Assumptions, finding, and issues. Language Learning, v. 38, n. 1, 1988. p. 101-126.

GARDNER, R. C.; LAMBERT, W. E. Motivational Variables in Second Language Acquisition. Canadian Journal of Psychology, v. 13, 1959. p. 266-272.

GOFFMAN, E. Interaction Ritual: Essays on Face to Face Behavior. New York: Garden City, 1967.

GUIORA, A. Z. The dialect of language acquisition. Language Learning, v. 33, 1983. p. 3-12. Disponível em: <https://onlinelibrary.wiley.com/doi/10.1111/j.14671770.1984.tb01321.x>. Acesso em: 1 mar. 2020.

HORWITZ, E. K.; HORWITZ M. B.; COPE, J. Foreign Language Classroom Anxiety. The Modern Language Journal, v. 70, n. 2, 1986. p. 125-132.

HYMES, D. H. Vers une compétence de communication. Paris: Crédif, Hatier, Didier, 1991.

ISARD, M.; SMITH, P. Between belief and transgression: Structuralism essays in religion, history and myth. Chicago: The University of Chicago Press. 1982.

JALIL, Samira Abel; PROCAILO, Leonilda. Metodologia de ensino de línguas estrangeiras: perspectivas e reflexões sobre os métodos, abordagens e o pósmétodo. PUCPR, 2009. Disponível em:

<https://educere.bruc.com.br/arquivo/pdf2009/2044_2145.pdf>. Acesso em: 28 mar. 2020.

JOHNSON, Karen E. The emerging beliefs and instructional practices of Preservice English as a second language Teachers. Teaching \& Teacher Education, v. 10, 1994. p. 439-452.

KLEIN, M. Inveja e gratidão: e outros trabalhos 1946-1963. Rio de Janeiro: Imago, 1991.

KRASHEN, S. D. The input hypothesis: issues and implications. New York: Longman, 1985. 
LAKOFF, Robin. Transformacional grammar and language teaching. In: ALLEN, Harold; CAMPBELL, Russell N. (Orgs.). Teaching English as a second language: a book of readings. Bombay: Tata McGraw-Hill, 1972.

LARSEN-FREEMAN, D. Teaching Techniques in English as a Second Language. Oxford: Oxford University Press, 2000.

LEFFA, Vilson J. Língua estrangeira. Ensino e aprendizagem. Pelotas, RS: EDUCAT, 2016.

LAZARUS, R. S. The cognition-emotion debate: a bit of history. In: DALGLEISH, T.; POWER, M. (Ed.). Handbook of cognition and emotion. New York: John Wiley \& Sons, 2000. p. 3-19.

LEITE, S. A. S. Afetividade nas práticas pedagógicas. Temas em Psicologia, v. 20, n. 2, 2012. p. 355-368.

LIGHTBOWN, Patsy M.; SPADA, Nina Margaret. How languages are learned. 3rd ed. Oxford: Oxford University Press, 2006.

MAY, Rollo. O significado de ansiedade: as causas da integração e desintegração da personalidade. Rio de Janeiro: Zahar, 1980.

MCLAUGHLIN, B. Second Language Acquisition in Childhood. Hillsdale: Lawrence Earlbaum, 1978.

MEDLEY, F. W., Jr. Motivational Considerations in the Teaching of Grammar. Proceedings of the Second Caribbean Language Conference - Instructional Innovation for the Foreign Language Classroom, Port of Spain, Trinidad y Tobago, 1992. p. 88-114.

MORAIS, Carlos Fernandes de. Representações sociais de professores do ensino fundamental sobre afetividade na prática docente. Rio de Janeiro: Gramma, 2018.

NASCIMENTO, Mariana Costa; CALSA, Geiva Carolina. Como aprendem os alunos ansiosos? A descentração e a tomada de consciência como prática pedagógica.

Schème - Revista Eletrônica de Psicologia e Epistemologia Genéticas, vol. 7, n. 2, ago./dez. 2015. Disponível em:

<http://www2.marilia.unesp.br/revistas/index.php/scheme/article/view/5782>. Acesso em: 29 fev. 2020.

PIAGET, J. Relações entre a afetividade e a inteligência no desenvolvimento mental da criança. Rio de Janeiro: Wak Editora, 2014.

PILETTI, N. História do Brasil. 12. ed. São Paulo: Ática, 1991. 
PINHEIRO, Márcia Regina Martins. A afetividade como auxílio à aprendizagem: Um estudo de caso em aulas de espanhol como língua estrangeira (ELE). Revista do ISAT. São Gonçalo, RJ, vol. 5, 2009. p. 138-206. Disponível em:

$<$ http://www.revistadoisat.com.br/numero5/005_A_Afetividade_Marcia_Pinheiro.pdf > . Acesso em: 7 mar. 2020.

PINTO, José Gouveia. Ansiedade Social: Da timidez à fobia social. Quarteto Editora, 2000.

RIBEIRO, M. L. A afetividade na relação educativa. Estudos Psicológicos, Campinas, v. 27, n. 3, 2010. p. 403-412. Disponível em:

<http://www.scielo.br/pdf/estpsi/v27n3/12.pdf>. Acesso em: 7 mar. 2020.

SANCHEZ PEREZ, A. La Enseñanza de Idiomas. Barcelona: Hora S. A. 1982.

SCHLATTER, Margarete; GARCEZ, Pedro de Moraes. Línguas adicionais na escola: aprendizagens colaborativas em inglês. Erechim, RS: Edelbra, 2012.

SILVA, Ana Beatriz Barbosa. Mentes Ansiosas: medo e ansiedade além dos limites. Rio de Janeiro: Objetiva, 2011.

SILVA, Giovana Rodrigues da.; SOARES, Adriana. Línguas estrangeiras no Brasil: um histórico ao longo dos anos. Faculdade Cenecista de Osório/Rio Grande do Sul, 2012. Disponível em:

<http://facos.edu.br/publicacoes/revistas/trajetoria_multicursos/dezembro_2012/pdf/li nguas_estrangeiras_no_brasil_-_um_historico_ao_longo_dos_anos.pdf $>$. Acesso em: 20 mar. 2020.

SILVEIRA, Fernanda Vieira da Rocha. Ressignificando a ansiedade na aprendizagem e uso de línguas estrangeiras através das crenças: um estudo exploratório. Tese (doutorado) - Pontifícia Universidade Católica do Rio de Janeiro, Departamento de Letras, 2012. Disponível em: <https://www.maxwell.vrac.pucrio.br/colecao.php?strSecao=resultado\&nrSeq=21054@1>. Acesso em: 7 mar. 2020.

SPIELBERGER, C. D.; GORSUCH, R. L.; LUSHENE, R. E. Manual for the StateTrait Anxiety Inventory. Palo Alto: Consulting Psychologist Press, 1970.

TASSONI, E. C. M. Afetividade e aprendizagem: a leitura e a escrita em foco. XVI ENDIPE - Unicamp, Campinas, 2012. Disponível em:

<http://23reuniao.anped.org.br/textos/2019t.pdf.> Acesso em: 7 mar. 2020.

ТÓTH, Zsusza. Foreign Language Anxiety and the Advanced Language

Learner: A Study of Hungarian Students of English as a Foreign Language.

Cambridge Scholars Publishing, 2010.

VELOSO, Waldir de Pinho. Como redigir trabalhos científicos. São Paulo: IOB Thomson, 2006.

VIEIRA, Sonia. Como elaborar questionários. São Paulo: Atlas, 2009. 
WELP, Anamaria Kurtz de Souza. A ansiedade e o aprendizado de língua estrangeira. Letras de Hoje, Porto Alegre, v. 44, n. 3, jul./set. 2009. p. 70-77. Disponível em:

<http://revistaseletronicas.pucrs.br/ojs/index.php/fale/article/view/5766/4186>. Acesso em: 1 mar. 2020.

YOUNG, D. J. Creating a low-anxiety classroom environment: what does language anxiety research suggest? The Modern Language Journal, v. 75, n. 3. 1991. Disponível em: <https://www.academia.edu/9357171/Creating_a_LowAnxiety_Classroom_Environment_What_Does_Language_Anxiety_Research_Sugge st>. Acesso em: 1 mar. 2020. 


\section{APÊNDICE $1^{3}$ \\ QUESTIONÁRIO PROFESSORES}

Nome:

Idioma de ensino:

Idade:

Sexo:

Formação:

\section{Responda às perguntas:}

1- Em qual/quais dessas habilidades você acha que seus alunos se sentem mais vulneráveis: leitura, escrita, fala ou compreensão oral? Por quê?

2- Os alunos se mostram mais receptivos com quais atividades aplicadas dentro de sala de aula? Como? Por quê?

3- Para você, qual é a importância da afetividade professor-aluno na aprendizagem de Língua Estrangeira?

4- Você acha que os alunos que já falam outros idiomas estrangeiros se sentem mais confortáveis ao aprender um novo idioma? Por quê?

5- Você tem alunos ansiosos? Como você os identifica? Você utiliza uma abordagem diferente com esses alunos?

6- Você fala outros idiomas? Quais? Você dá aula de outros idiomas? Quais?

\footnotetext{
${ }^{3}$ Os questionários aplicados aos professores de francês e inglês foram os mesmos.
} 


\section{APÊNDICE 2}

\section{QUESTIONÁRIO ALUNOS CURSANDO FRANCÊS}

Nome:

Idade: Sexo: Nível de francês:

Nível de escolaridade:

( ) Sem escolaridade

( ) Ensino Médio Incompleto

( ) Ensino Médio Completo

( ) Nível Superior Incompleto

( ) Nível Superior Completo

( ) Pós-Graduação

( ) Outro(s):

\section{Responda às perguntas:}

1- O que você acha das aulas de francês?

2- Por que escolheu estudar francês?

3- O que você acha do seu professor de francês?

4- Para você, qual é a importância da relação professor-aluno para sua aprendizagem? Por quê?

5- Com qual/quais dessas habilidades você se sente mais confortável: leitura, escrita, fala ou compreensão oral? Por quê?

6- Com qual/quais das habilidades descritas acima você se sente mais desconfortável? Por quê?

7- Como você se sente quando o professor faz perguntas em francês diretamente a você?

8- Qual/Quais sentimentos a sala de aula traz a você?
( ) Segurança
() Motivação
( ) Ansiedade
() Medo
( ) Outro(s):

9- De quais atividades aplicadas na aula de língua francesa você mais gosta?

10- Você fala outros idiomas? Se sim, quais? Você acredita que falar outro idioma facilitou seu aprendizado de língua francesa? Por quê?

11- Você já estudou francês antes ou é a primeira vez? Se já, qual foi o motivo da desistência anteriormente? 


\section{APÊNDICE 3 \\ QUESTIONÁRIO ALUNOS \\ FORMADOS EM FRANCÊS}

Nome:

Onde se formou:

Idade:

Sexo:

Nível de francês:

Nível de escolaridade:

( ) Sem escolaridade

( ) Ensino Médio Incompleto

( ) Ensino Médio Completo

( ) Nível Superior Incompleto

( ) Nível Superior Completo

( ) Pós-Graduação

( ) Outro(s):

\section{Responda às perguntas:}

1- O que você achava das aulas de francês?

2- Por que escolheu estudar francês?

3- O que você achava dos seus professores de francês?

4- Para você, qual era a importância da relação professor-aluno para sua aprendizagem? Por quê?

5- Com qual/quais dessas habilidades você se sentia mais confortável: leitura, escrita, fala ou compreensão oral? Por quê?

6- Com qual/quais das habilidades descritas acima você se sentia mais desconfortável? Por quê?

7- Como você se sentia quando o professor fazia perguntas em francês diretamente a você?

8- Qual/Quais sentimentos a sala de aula trazia a você?
( ) Segurança
( ) Motivação
( ) Ansiedade
( ) Medo
( ) Outro(s):

9- De quais atividades aplicadas na aula de língua francesa você mais gostava?

10- Você fala outros idiomas? Se sim, quais? Você acredita que falar outro idioma facilitou seu aprendizado de língua francesa? Por quê?

11- Você desistiu do curso em algum momento? Se sim, qual foi o motivo? 


\section{APÊNDICE 4 \\ QUESTIONÁRIO ALUNOS CURSANDO INGLÊS}

Nome:

Idade: Sexo: Nível de inglês:

Nível de escolaridade:

( ) Sem escolaridade

( ) Ensino Médio Incompleto

( ) Ensino Médio Completo

( ) Nível Superior Incompleto

( ) Nível Superior Completo

( ) Pós-Graduação

( ) Outro(s):

\section{Responda às perguntas:}

1- O que você acha das aulas de inglês?

2- Por que escolheu estudar inglês?

3- O que você acha do seu professor de inglês?

4- Para você, qual é a importância da relação professor-aluno para sua aprendizagem? Por quê?

5- Com qual/quais dessas habilidades você se sente mais confortável: leitura, escrita, fala ou compreensão oral? Por quê?

6- Com qual/quais das habilidades descritas acima você se sente mais desconfortável? Por quê?

7- Como você se sente quando o professor faz perguntas em inglês diretamente a você?

8- Qual/Quais sentimentos a sala de aula traz a você?
( ) Segurança
( ) Motivação
( ) Ansiedade
( ) Medo
( ) Outro(s):

9- De quais atividades aplicadas na aula de língua inglesa você mais gosta?

10- Você fala outros idiomas? Se sim, quais? Você acredita que falar outro idioma facilitou seu aprendizado de língua inglesa? Por quê?

11- Você já estudou inglês antes ou é a primeira vez? Se já, qual foi o motivo da desistência anteriormente? 


\section{APÊNDICE 5 \\ QUESTIONÁRIO ALUNOS \\ FORMADOS EM INGLÊS}

Nome:

Onde se formou:

Idade:

Sexo:

Nível de inglês:

Nível de escolaridade:

( ) Sem escolaridade

( ) Ensino Médio Incompleto

( ) Ensino Médio Completo

( ) Nível Superior Incompleto

( ) Nível Superior Completo

( ) Pós-Graduação

( ) Outro(s):

\section{Responda às perguntas:}

1- O que você achava das aulas de inglês?

2- Por que escolheu estudar inglês?

3- O que você achava dos seus professores de inglês?

4- Para você, qual era a importância da relação professor-aluno para sua aprendizagem? Por quê?

5- Com qual/quais dessas habilidades você se sentia mais confortável: leitura, escrita, fala ou compreensão oral? Por quê?

6- Com qual/quais das habilidades descritas acima você se sentia mais desconfortável? Por quê?

7- Como você se sentia quando o professor fazia perguntas em inglês diretamente a você?

8- Qual/Quais sentimentos a sala de aula trazia a você?
( ) Segurança
( ) Motivação
( ) Ansiedade
( ) Medo
( ) Outro(s):

9- De quais atividades aplicadas na aula de língua inglesa você mais gostava?

10- Você fala outros idiomas? Se sim, quais? Você acredita que falar outro idioma facilitou seu aprendizado de língua inglesa? Por quê?

11- Você desistiu do curso em algum momento? Se sim, qual foi o motivo? 